\title{
Low glycaemic index diets for coronary heart disease (Review)
}

\author{
Kelly SAM, Frost G, Whittaker V, Summerbell CD
}

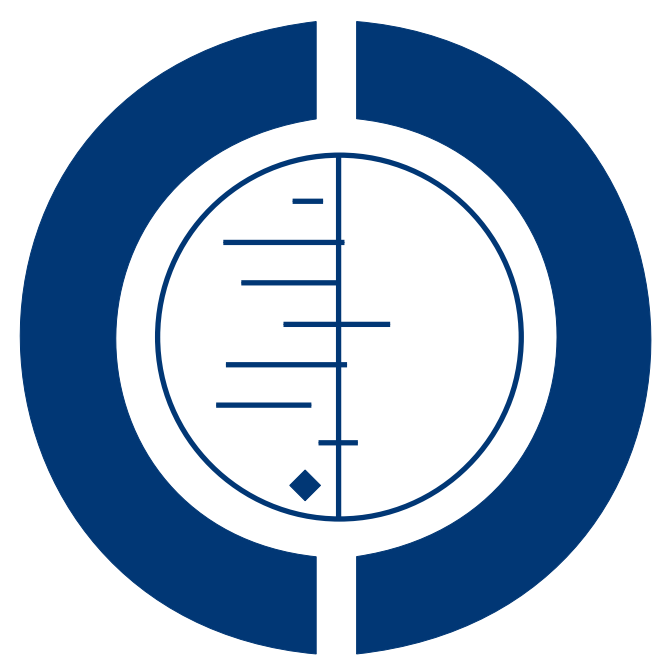

\section{THE COCHRANE COLLABORATION $^{\circledR}$}

This is a reprint of a Cochrane review, prepared and maintained by The Cochrane Collaboration and published in The Cochrane Library 2008, Issue 4

http://www.thecochranelibrary.com

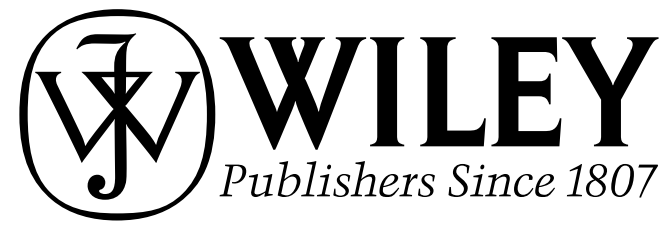

Low glycaemic index diets for coronary heart disease (Review)

Copyright (C) 2008 The Cochrane Collaboration. Published by John Wiley \& Sons, Ltd. 
TABLE OF CONTENTS

HEADER . . . . . . . . . . . . . . . . . . . . . . . . . . . . . . . . . . . . . . . 1

ABSTRACT . . . . . . . . . . . . . . . . . . . . . . . . . . . . . . . . . . . . . . . . . . . . . $\quad 1$

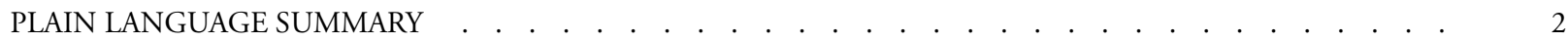

BACKGROUND . . . . . . . . . . . . . . . . . . . . . . . . . . . . . . . . . . . . 2

OBJECTIVES . . . . . . . . . . . . . . . . . . . . . . . . . . . . . . . . . . . . . 44

METHODS . . . . . . . . . . . . . . . . . . . . . . . . . . . . . . . . . . . . . . 4

RESULTS . . . . . . . . . . . . . . . . . . . . . . . . . . . . . . . . . . . . . . . 7

DISCUSSION . . . . . . . . . . . . . . . . . . . . . . . . . . . . . . . . . . . . . 12

AUTHORS' CONCLUSIONS . . . . . . . . . . . . . . . . . . . . . . . . . . . . . . . 13

ACKNOWLEDGEMENTS . . . . . . . . . . . . . . . . . . . . . . . . . . . . . . . . . . . . . . . . . .

REFERENCES . . . . . . . . . . . . . . . . . . . . . . . . . . . . . . . . . . . . . 14

CHARACTERISTICS OF STUDIES . . . . . . . . . . . . . . . . . . . . . . . . . . . . . 19

DATA AND ANALYSES . . . . . . . . . . . . . . . . . . . . . . . . . . . . . . . . . . . . . . . . . . 45

Analysis 1.1. Comparison 1 Total cholesterol (parallel and cross-over studies), Outcome 1 All endpoint outcomes $(\mathrm{mmol} / \mathrm{L})$.

Analysis 2.1. Comparison 2 Total cholesterol (whole-diet studies only, parallel and crossover studies), Outcome 14 and 5 week outcomes $(\mathrm{mmol} / \mathrm{L}) . \quad$. . . . . . . . . . . . . . . . . . . . . . . . . . . . .

Analysis 2.2. Comparison 2 Total cholesterol (whole-diet studies only, parallel and crossover studies), Outcome 212 week outcomes $(\mathrm{mmol} / \mathrm{L})$

Analysis 2.3. Comparison 2 Total cholesterol (whole-diet studies only, parallel and crossover studies), Outcome 3 All endpoint outcomes $(\mathrm{mmol} / \mathrm{L})$.

Analysis 3.1. Comparison $3 \mathrm{HDL}$ cholesterol (parallel and cross-over studies), Outcome 1 All endpoint outcomes $(\mathrm{mmol} / \mathrm{L})$.

Analysis 4.1. Comparison 4 HDL cholesterol (parallel studies only), Outcome 14 and 5 week outcomes (mmol/L). .

Analysis 4.2. Comparison 4 HDL cholesterol (parallel studies only), Outcome 212 week outcomes. . . . . . .

Analysis 5.1. Comparison 5 LDL cholesterol (parallel and cross-over studies), Outcome 1 All endpoint outcomes $(\mathrm{mmol} / \mathrm{L})$.

Analysis 5.2. Comparison 5 LDL cholesterol (parallel and cross-over studies), Outcome 2 All endpoint outcomes (without Wolever 2002 study).

Analysis 6.1. Comparison 6 Triglycerides (parallel and cross-over studies), Outcome 1 All endpoint data (mmol/L). .

Analysis 7.1. Comparison 7 Body weight (parallel and cross-over studies), Outcome 1 All endpoint outcomes (kg).

Analysis 8.1. Comparison 8 Fasting glucose (parallel and cross-over studies), Outcome 1 All endpoint outcomes $(\mathrm{mmol} / \mathrm{L})$.

Analysis 9.1. Comparison 9 Fasting insulin (parallel and cross-over studies), Outcome 1 All endpoint outcomes. . .

Analysis 10.1. Comparison $10 \mathrm{HbA1c}$ (parallel and cross-over studies), Outcome 1 All endpoint outcomes (\%). . .

Analysis 10.2. Comparison $10 \mathrm{HbA1c}$ (parallel and cross-over studies), Outcome 212 week outcomes (\%).

Analysis 10.3. Comparison $10 \mathrm{HbA1c}$ (parallel and cross-over studies), Outcome 312 week outcomes (\%) without Frost 1996.

APPENDICES

WHAT'S NEW

HISTORY

CONTRIBUTIONS OF AUTHORS

DECLARATIONS OF INTEREST

INDEX TERMS 


\title{
[Intervention Review]
}

\section{Low glycaemic index diets for coronary heart disease}

\author{
Sarah AM Kelly ${ }^{1}$, Gary Frost ${ }^{2}$, Victoria Whittaker ${ }^{3}$, Carolyn D Summerbell ${ }^{3}$ \\ ${ }^{1}$ School of Dental Sciences, University of Newcastle, Newcastle upon Tyne, UK. ${ }^{2}$ Department of Nutrition and Dietetics, Hammersmith \\ Hospital, London, UK. ${ }^{3}$ School of Health and Social Care, University of Teesside, Middlesbrough, UK \\ Contact address: Sarah AM Kelly, School of Dental Sciences, University of Newcastle, Newcastle upon Tyne, NE1 7RU, UK. \\ s.a.m.kelly@newcastle.ac.uk.
}

Editorial group: Cochrane Heart Group.

Publication status and date: New search for studies and content updated (no change to conclusions), published in Issue 4, 2008.

Review content assessed as up-to-date: 14 May 2006.

Citation: Kelly SAM, Frost G, Whittaker V, Summerbell CD. Low glycaemic index diets for coronary heart disease. Cochrane Database of Systematic Reviews 2004, Issue 4. Art. No.: CD004467. DOI: 10.1002/14651858.CD004467.pub2.

Copyright (C) 2008 The Cochrane Collaboration. Published by John Wiley \& Sons, Ltd.

\section{A B S T R A C T}

\section{Background}

The glycaemic index (GI) is a physiological measure of the ability of a carbohydrate to affect blood glucose. Interest is growing in the low GI carbohydrate concept for the clinical management of people at risk of, or with established coronary heart disease. There is a need to review the current evidence from randomised controlled trials (RCTs) in this area.

\section{Objectives}

To review evidence from RCTs assessing the relationship between the consumption of low GI diets and the effects on coronary heart disease (CHD) and related risk factors in people who have established CHD or risk factors.

\section{Search strategy}

We searched CENTRAL on The Cochrane Library (Issue 2, 2006), MEDLINE (1966 to July 2006), EMBASE (1980 to July 2006) and CINAHL (1982 to July 2006). We checked references and contacted experts in the field. No language restrictions were applied.

\section{Selection criteria}

We selected RCTs that assessed the effects of low GI diets, over a minimum of 4 weeks, on CHD and risk factors for CHD. Participants included were adults with at least one major risk factor for CHD e.g. abnormal lipids, diabetes or being overweight or who had previously been diagnosed with CHD.

\section{Data collection and analysis}

Two reviewers independently assessed trial quality and extracted data. Authors of the included studies were contacted for additional information where necessary.

\section{Main results}

Twenty-one RCTs were included, with a total of 713 participants randomised. No studies were found that reported the effect of low GI diets on CHD mortality or CHD events and morbidity. All 21 included studies report the effect of low GI diets on risk factors for CHD. Meta-analysis detected limited and weak evidence of slightly lower total cholesterol with low glycaemic index diets. However, when only studies on diabetics were included in the analysis, no evidence of an effect on total cholesterol was found. There is little evidence from the combination of studies in meta-analysis that low glycaemic index diets have an effect on LDL cholesterol, HDL cholesterol, triglycerides, glycosylated haemoglobin (HbA1c), fasting glucose or fasting insulin levels. However, the majority of individual studies do report slightly lower levels of glycosylated haemoglobin (HbA1c) with low GI diets. 


\section{Authors' conclusions}

There is no evidence from RCTs to show an effect of low GI diets on coronary heart disease. Weak evidence for minor effects on some $\mathrm{CHD}$ risk factors was found. Many of the trials identified were short-term, of poor quality and did not have sufficient power to detect clinically important differences. The combined evidence from the studies suggests that any beneficial effect of low glycaemic index diets on CHD and its risk factors is small. There is a need for well designed, adequately powered, randomised controlled studies, of greater than 12 weeks duration to assess the true effects of low glycaemic index diets for CHD.

\section{PLAIN LANGUAGE SUMMARY}

\section{Low glycaemic index diets for coronary heart disease}

The glycaemic index is a measure of the ability of a carbohydrate to affect blood glucose levels. While there are many randomised controlled trials that have examined the relationship between low glycaemic index diets and coronary heart disease, most are of poor methodological quality. There is little evidence from the randomised controlled trials to recommend that healthcare professionals should prescribe low glycaemic index diets for the purpose of improving risk factors for CHD.

\section{B A C K G R O U N D}

In western society, coronary heart disease (CHD) is the major cause of death and the prevalence of CHD is increasing worldwide (Murray 1997). In the UK in 1997, there were 238 deaths from CHD per 100,000 population (OHE 1999) and, in England and Wales in 1996, 20\% of men and 12\% of women over 65 years of age were treated for CHD by general practitioners (Carter 1999).

An association between CHD and dietary fat intake is well-documented but the role of dietary carbohydrate in CHD is not. There is increasing evidence from observational non-randomised studies that the glycaemic index (GI) of dietary carbohydrates may be important in disease prevention and control (Brand-Miller 2002; Frost 2000; Leeds 2002; Rizkalla 2002). The World Health Organisation has recommended that dietary carbohydrates be classified according to their glycaemic index and that the methodology for assessing the glycaemic index should be standardised (FAO/ WHO 1997).

The concept of glycaemic index was first proposed in 1981(Jenkins 1981). The glycaemic index of a dietary carbohydrate is an assessment of its post-prandial effect on blood glucose. The lower the glycaemic index, the smaller the effect of the carbohydrate on post-prandial glucose levels. The GI classification is a standardised comparison of the 2-hour post-prandial glucose response to $50 \mathrm{~g}$ of a carbohydrate with that of $50 \mathrm{~g}$ of white bread or glucose, calculated from the area under the glucose response curve. The GI of white bread and of glucose is 100 and all other carbohydrate foods have GI between 0 and 100. The GI of a carbohydrate depends on its rate of intestinal absorption, which can be influenced by its composition and ease of digestion (Frost 2000). Low glycaemic index carbohydrates have lower 2-hour areas under the glucose curve than white bread, while high glycaemic index foods have higher areas.

Cooking and food preparation can modify the glycaemic index of foods. Highly processed convenience foods tend to have high GI. Cooked pulse vegetables have low GI as their cell walls are resistant to cooking. The intact cereal grains of rye and granary bread all have low glycaemic indexes. However, when granary bread is processed to wholemeal bread, the grains are disrupted giving higher GI. Some examples of GI of common carbohydrate foods are given in Table 1 (Frost 2000).

Table 1. Glycaemic index values for food types

\begin{tabular}{l|l}
\hline Food type & Glycaemic index \\
\hline White bread & 100 \\
\hline Wholemeal bread & 100
\end{tabular}


Table 1. Glycaemic index values for food types (Continued)

\begin{tabular}{ll}
\hline Weetabix & 100 \\
\hline Cornflakes & 119 \\
\hline Porridge & 87 \\
\hline Baked beans & 69 \\
\hline Digestive biscuits & 84 \\
\hline Apple & 52 \\
\hline
\end{tabular}

In 1995, the first international tables of glycaemic index were published (Foster-Powell 1995). The tables were updated in 2002 (Foster-Powell 2002) and the methodology on their derivation has also been reported (Jenkins 1981; Wolever 1990). The tables list GI of individual foods. Prior to the WHO 1997 report ( FAO/WHO 1997) on dietary carbohydrates that standardised the method of measurement of GI of foods, different groups used different techniques to calculate the area under the glucose response curve. However, the published glycaemic index tables have provided conversion factors or have presented tables using different methods alongside one another.

The glycaemic index of a mixed meal can be calculated from the different proportions of each of the carbohydrate containing foods and their individual glycaemic index values. For example, when bread and beans are mixed in equal quantities, the resulting glycaemic response is midway between that of bread alone and beans alone (Wolever 1985; Wolever 1986). The addition of fat to a mixed meal reduces the glycaemic response (Bornet 1987; Coulston 1987; Wolever 1988) but the relative response of one carbohydrate to another remains. For example, baked beans (69) have a lower GI than white bread (100) so baked beans will always give a lower glycaemic response than white bread when part of a mixed meal. Alternatively, the glycaemic index for a mixed meal can be measured from the area under the glucose response curve of the mixed meal. However, both the quality and the quantity of carbohydrate are associated in the response of an individual to foods (Barclay 2005; Sheard 2004).

In a large prospective study a diet high in carbohydrates with high GI were linked to the development of coronary heart disease in women at 10-year follow-up (Liu 2000). Two cross-sectional studies have shown that low GI diets are associated with high density lipoproteins (HDL) cholesterol concentrations (Ford 2001; Frost 1999b). In hyperlipidaemic subjects, low glycaemic index diets have been shown to lower serum cholesterol and triglyceride levels (Jenkins 1987a). Obesity is also a risk factor for CHD. Energyrestricted diets based on low GI foods produced greater weight loss in obese populations than did equivalent diets based on high GI foods (Brand-Miller 2002). A systematic review assessing the effect of a low glycaemic index diet in the management of diabetes mellitus reported an average drop in HbAlc of 0.5 percent point (Brand-Miller 2003). This is approximately half the drop seen in the UK Prospective Diabetes Study study, which suggests a significant clinical impact of this intervention (UKPDS 35).

Patients with diabetes are predisposed to coronary heart disease. Mortality rates from coronary heart disease are up to five times higher than the general population for people with diabetes $(\mathrm{DoH}$ 2001). Low glycaemic index diets have been shown to lead to improved glycaemic control as well as several metabolic parameters such as blood lipids in people with diabetes (Frost 1994; Rizkalla 2002).

Reduced insulin sensitivity is one component of a cluster of metabolic and cardiovascular factors which contribute to the metabolic environment that predisposes to CHD (Reaven 1993) and which are associated with altered post-prandial metabolism. Insulin resistance is a condition in which the body does not respond to the action of insulin although enough insulin is produced. There is evidence of reduced insulin sensitivity at diagnosis in $60 \%$ of patients with CHD (Ferrannini 1991). Low GI diets have been shown to improve insulin sensitivity (Frost 1998a). Although the insulin response is not used to define glycaemic index, the lower the glycaemic index of a food the more attenuated is the insulin response to a standard test meal (Bornet 1987).

Given this suggestive evidence of benefit of low GI diets, largely 
from observational studies which may be prone to confounding and other biases, a systematic review of the randomised trial evidence was undertaken.

\section{O B JE C T IVES}

The aim of this systematic review was to assess the effect of glycaemic index of carbohydrates or diet on total mortality, CHD events and risk factors for coronary heart disease, using all available randomised controlled trials and concurrent controlled trials and meta-analytic techniques when appropriate.

The primary question to be answered by the review was:

Do low glycaemic index diets reduce total mortality from CHD, CHD events or risk factors for CHD in people diagnosed with $\mathrm{CHD}$ or with at least one major risk factor for CHD?

\section{METHODS}

\section{Criteria for considering studies for this review}

\section{Types of studies}

Randomised controlled studies (RCTs). Crossover studies and parallel studies were included and crossover trials analysed separately within the meta-analysis. Trials were only included if outcome data could be collected (by communication with authors when necessary).

\section{Types of participants}

Non-institutionalised people (age $>16$ ) with at least one major risk factor for coronary heart disease or with diagnosed coronary heart disease were included. Participants were considered to be free-living if they were out-patients and/or lived at home. However, children (age $<16$ years) were excluded. Major risk factors for CHD include abnormal lipid levels (HDL and low density lipoproteins (LDL) cholesterol, triglycerides and total cholesterol), diabetes, family history of CHD, raised blood pressure, hypertension, overweight (body mass index >25), abdominal obesity, impaired glucose tolerance, reduced insulin sensitivity, insulin resistance, hyperinsulinaemia, hyperglycaemia, abnormal clotting factors.

Studies which reported participants with current or previous coronary heart disease (which includes myocardial infarction, coronary artery bypass graft or percutaneous transluminal coronary angioplasty, or with angina pectoris or coronary artery disease defined by angiography) were included. Studies which reported participants on medication were included.

Participants could be of either sex but those studies in which participants were reported to be pregnant or acutely ill e.g. those with diagnosed cancer, those in preparation for or who had undergone heart or renal transplants, with HIV or AIDS, on haemo- or peritoneal dialysis, or with any renal problem were excluded. Studies which reported participants with congenital heart disease were excluded. Studies on participants who were institutionalised or who were in-patients in hospitals, homes or clinics were excluded.

\section{Types of interventions}

The intervention had to be advice on diet or carbohydrate foods, or a prescribed diet when the glycaemic index of the diet or carbohydrate foods were reported or compared and the effect on risk factors for CHD or CHD events or mortality were reported. Studies needed to have a minimum of 4 weeks intervention period. Comparisons had to be between diets with similar overall carbohydrate and fat levels and similar levels of energy and macronutrients.

Studies did not need to specifically aim to compare the effect of glycaemic index of the diet but if the glycaemic indices were reported and the diets had similar carbohydrate, fat and energy levels, they were included. Studies which compared the effect of lower GI diets or foods with any higher GI diets or foods were included.

Metabolic ward studies, conducted on-inpatients, were not included as the participants are not free-living. Studies were not included if they were multiple component interventions which included factors other than glycaemic index of the diet, unless the effect of glycaemic index of diet could be separated out from the other interventions.

\section{Types of outcome measures}

\section{Primary outcomes}

1. Total CHD mortality;

2. Combined CHD events and morbidity (to include fatal and non fatal myocardial infarction, angina, unplanned coronary artery bypass graft or percutaneous transluminal coronary angioplasty);

3. Changes in the severity of major risk factors for CHD including lipids (HDL, LDL cholesterol levels, triglycerides and total cholesterol), measures of diabetic control (including changes in medication, glycosylated haemoglobin, glucose tolerance and control), overweight, blood pressure, insulin resistance, insulin sensitivity, hyperinsulinaemia, hyperglycaemia.

\section{Secondary outcomes}

1. Quality of life;

2. Attitudes to diets; and

3. Problems such as bloating, nausea, weight gain, difficulty in eating out, weight gain were noted. 


\section{Search methods for identification of studies}

\section{Electronic searches}

Searches were conducted in the Cochrane Central Register of Controlled Trials (CENTRAL) in The Cochrane Library (Issue 2 2006), MEDLINE (1966 to July 2006), EMBASE (1980 to July 2006), CINAHL (1982 to July 2006). See Appendix 1 for details of search strategies. No language restrictions were applied

\section{Searching other resources}

1. The reference lists of all included studies were checked.

2. Known experts in the field were consulted.

3. Relevant published reviews were also sought as a source of RCTs.

\section{Data collection and analysis}

\section{Selection of studies}

The titles and abstracts of retrieved records were scanned and were only rejected if the reviewer could determine that they definitely did not meet the inclusion criteria. Full texts were obtained for any that could not be rejected with certainty. Each paper was then assessed independently by two reviewers. An in/out form was used to assess the inclusion (or otherwise) of full papers into the review. If a trial was excluded after the full paper has been obtained, a record of the study and reason for exclusion was recorded.

\section{Data extraction and management}

Original reports of trial results were extracted by two reviewers independently. Differences between reviewers' extraction results were resolved by discussion and, when necessary, in consultation with a third reviewer.

Data was extracted as follows and is reported in the characterisitics of included studies table:

1. General information: published/unpublished, title, authors, source, country, year of publication, duplicate publications;

2. Trial characteristics: design, duration, randomisation (and method), allocation concealment (and method), blinding (outcome assessors), check of blinding;

3. Intervention: dietary information/diet provided, length of intervention, comparison interventions, method of calculating glycaemic index;

4. Participants: sampling (random/convenience), exclusion criteria, total number and number in comparison groups, gender/age, diagnosis of CHD or risk factors, similarity of groups at baseline, withdrawals/losses to follow-up, assessment of compliance, medications used, smoking status when provided;
5. Outcomes: outcomes as specified above, the main outcome assessed in the study, other events, length of follow-up;

6. Results: for outcomes and times of assessment.

\section{Assessment of risk of bias in included studies}

The quality of each trial was assessed based largely on the quality criteria specified in the Cochrane Reviewers Handbook (Section 4.1.6). Trial quality was independently assessed by two reviewers. Studies were not excluded on the basis of a low quality score. In particular the following factors were examined.

1. Method of randomisation: each factor was marked as 'done', 'not done' or 'unclear'. Could the study be described as randomised (including use of words such as "random", "randomly" and "randomisation")?

Did the study describe the method of randomisation and was it an appropriate method? A method to determine the sequence of randomisation was regarded as appropriate if it allowed each study participant to have the same chance of receiving each intervention and the investigators could not predict which treatment was next. Methods of allocation using date of birth, date of admission, hospital numbers, or alternation were not regarded as appropriate. 2. Concealment of allocation: scored A (adequate), B (unclear), C (inadequate), following criteria adopted from the Cochrane Reviewer's Handbook (Section 4.1.6) and Schulz 1995.

A - Adequate measures to conceal allocations such as central randomisation; serially numbered, opaque, sealed envelopes; or other descriptions with convincing concealment.

B - Unclearly concealed trials, in which the authors either did not report allocation concealment at all, or reported an approach that did not fall into one of the categories in (A).

$\mathrm{C}$ - Inadequately concealed trials, in which the method of allocation was not concealed, such as alteration methods or use of case record numbers.

3. Blinding: each factor was marked as 'done', 'not done' or 'unclear'. With lifestyle interventions, such as the topic for this review, it is difficult to blind participants and those providing dietary advice, so this was not sought. However, it is possible to blind outcome assessors and this was marked as 'done', 'not done' or 'unclear'.

4. Intention-to-treat analysis: was marked as 'done', 'not done' or 'unclear'. Whether an intention-to-treat analysis was possible on all patients from the published data (i.e. whether there were any exclusions from the trial after randomisation) and the number of patients who were lost to follow-up. If there were no withdrawals it should be stated in the article. An intention-to-treat analysis was considered adequate if outcome data was analysed for all participants randomised.

Based on these criteria, studies were subdivided into the following three categories (see Cochrane Handbook, section 6.7.1):

A - all quality criteria met: low risk of bias. 
B - one or more of the quality criteria only partly met: moderate risk of bias.

C - one or more criteria not met: high risk of bias.

\section{Data synthesis}

For the purposes of pooling data, serum and plasma cholesterol measurements were converted to units of $\mathrm{mmol} / \mathrm{L}$. In some studies outcome data were reported in $\mathrm{mg} / \mathrm{dL}$. This was converted to $\mathrm{mmol} / \mathrm{L}$ by multiplying by conversion factors of 0.0259 for total, HDL and LDL cholesterol; 0.0113 for triglycerides; and 0.0555 for glucose (JAMA 2004). When insulin was reported in $\mu \mathrm{IU} / \mathrm{mL}$ it was converted to $\mathrm{pmol} / \mathrm{L}$ by multiplying by a conversion factor of 6.945 (JAMA 2004). Where body weight was reported in pounds it was converted to kilograms by multiplying by a conversion factor of 0.45 .

Fasting glucose outcomes were reported in the studies as either blood glucose, serum glucose or plasma glucose. All have been pooled in the meta-analysis after conversion to the same units of measurement $(\mathrm{mmol} / \mathrm{L})$, as the pooled analysis examines the differences between the values.

When data were available, sufficiently similar and of sufficient quality, statistical analyses were performed using the RevMan software. Heterogeneity between trial results was tested for using a standard chi-squared test. A p-value $<0.1$ was used to indicate that significant heterogeneity was present. Tests of heterogeneity were used for examining whether the observed variation in study results was compatible with variation expected with chance alone. If heterogeneity was found, then data were not pooled. We indicated in our protocol that primary outcomes of interest were:

1. Total mortality;

2. Cardiovascular events and morbidity; and

3. Risk factors for CHD.

And that when appropriate, recorded post treatment values or outcomes at the end of the study would be pooled using relative risk for dichotomous outcomes and for continuously distributed data weighted mean differences using a fixed-effect model.

No data on mortality or cardiovascular events were reported in the studies, data was identified in the included trials for the following outcomes:

- total cholesterol (mmol/L);

- HDL cholesterol ( $\mathrm{mmol} / \mathrm{L})$;

- LDL cholesterol ( $\mathrm{mmol} / \mathrm{L})$;

- triglycerides (mmol/L);

- body weight $(\mathrm{kg})$;

- fasting glucose $(\mathrm{mmol} / \mathrm{L})$;

- fasting insulin $(\mathrm{mmol} / \mathrm{L})$;

- glycosylated haemoglobin/HbA1c (\%);

- blood pressure;

- insulin resistance/insulin sensitivity.

By applying the principle for appropriate pooling that data from at least three studies are required for meta-analysis it was determined that sufficient data for pooling in this review existed only at the 45 week, 12 week and end-of-study intervals. Therefore, no pooling of outcome data other than at these three intervals was done. Metaanalysis has not been performed when less than 3 studies reported outcome data.

Data reported 4 to 5 week post-treatment for interventions of 4 or 5 weeks duration were pooled, including any 4 to 5 week data from studies of longer duration.

Data reported 12 weeks post treatment for interventions of 12 weeks duration were pooled, including any 12 week data from studies of longer duration.

Data reported at the end of the study (end-of-study-data) has been combined irrespective of the length of the study. Table 2 summarizes the duration of each study.

Data from parallel and crossover studies have been combined within the meta-analysis and have also been analysed separately.

Table 2. Summary of length of interventions (endpoints)

\begin{tabular}{ll}
\hline Study & Length \\
\hline Bouche & 5 weeks \\
\hline Brand & 12 weeks \\
\hline Calle-Pascual & 4 weeks \\
\hline Carels & 20 weeks (follow-up at 1 yr) \\
\hline Fontvielle & 5 weeks \\
\hline Frost 1994 & 12 weeks
\end{tabular}


Table 2. Summary of length of interventions (endpoints) (Continued)

\begin{tabular}{|c|c|}
\hline Frost 1996 & 4 weeks \\
\hline Frost 2004 & 12 weeks \\
\hline Giacco & 24 weeks \\
\hline Heilbronn & 8 weeks \\
\hline Jiminez-Cruz & 6 weeks \\
\hline Kabir & 4 weeks \\
\hline Komindr & 4 weeks \\
\hline Luscombe & 4 weeks \\
\hline Patel & 4 weeks \\
\hline Raatz & 24 weeks \\
\hline Sloth & 10 weeks \\
\hline Taghrid & 4 weeks \\
\hline Tshilias & 6 months \\
\hline Wolever 1992a & 6 weeks \\
\hline Wolever 2002 & 16 weeks \\
\hline
\end{tabular}

The data pooled in meta-analysis were final values. However, in two studies, only change-from-baseline data was available. In one study (Wolever 2002) only change-from-baseline data was available for total cholesterol, HDL cholesterol, LDL cholesterol, triacylglycerols and body weight outcomes. One study reported only change-from-baseline data for bodyweight (Raatz 2005). It can be appropriate to combine final values and change-from-baseline values (Cochrane 2002). For analyses that included the Wolever and Raatz studies, change data was combined with the final values from other studies. However, sensitivity analysis has also been conducted in those cases in the meta-analysis in which these studies contribute a significant amount to the overall pooled result, in order to examine the influence of the change-from baseline data on the pooled result. One study reported only baseline and changefrom-baseline values (Tsihlias 2000). In this case endpoint values have been calculated and the standard deviation has been assumed to be equivalent to the baseline standard deviation as the values are similar. As three of the 15 studies substituted low GI carbohydrates in only one meal per day the sensitivity of the results to these studies has also been examined. The results were re-analysed pooling only the data from the 12 'whole-diet' studies. The results of sensitivity analysis are reported separately within each comparison section.

\section{R E S U L T S}

\section{Description of studies}

See: Characteristics of included studies; Characteristics of excluded studies. 
The search yielded 4615 references. After reading titles and abstracts 97 full papers were obtained for further examination. From these 25 papers, reporting on 21 separate studies, met the inclusion criteria.

\section{Overview}

Details of the studies are shown in the table of characteristics of included studies. The column headed 'methods' presents the results of the quality assessment (see methods of the review). The column headed 'notes' includes details of the reported GI of the diets.

Of the 21 included studies ten were of randomised crossover design (Bouche 2002; Brand 1991; Calle-Pascual 1988; Fontvielle 1992; Jimenez-Cruz 2003a; Kabir 2002; Komindr 2001; Luscombe 1999; Taghrid 2004; Wolever 1992a) and 11 studies (Frost 1994; Frost 1996; Giacco 2000; Heilbronn 2002; Tsihlias 2000; Wolever 2002; Carels 2005; Frost 2004; Patel 2004; Raatz 2005; Sloth 2004) were parallel randomised controlled trials.

\section{Population and setting}

In three studies participants were diagnosed with advanced coronary heart disease (Frost 1996; Frost 2004; Patel 2004), and eleven studies were on diabetics (Brand 1991; Calle-Pascual 1988; Fontvielle 1992; Frost 1994; Giacco 2000; Kabir 2002; Komindr 2001; Luscombe 1999; Taghrid 2004; Tsihlias 2000; Wolever 1992a). In four studies, participants were overweight (Bouche 2002; Carels 2005; Raatz 2005; Sloth 2004), in two studies participants were both diabetic and overweight (Jimenez-Cruz 2003a; Heilbronn 2002) and in one other study they had impaired glucose tolerance and at least one risk factor for diabetes (Wolever 2002).

Of the eleven studies in which the participants were diagnosed with diabetes: in eight studies, the participants had Type 2 diabetes (NIDDM) (Brand 1991; Frost 1994; Kabir 2002; Komindr 2001; Luscombe 1999; Taghrid 2004; Tsihlias 2000; Wolever 1992a); in one study, Type 1 diabetes (Giacco 2000); and two studies included those with both Type 1 and Type 2 diabetes (Calle-Pascual 1988; Fontvielle 1992). In the two studies in people who were reported to be both overweight and diabetic, the participants were diagnosed with Type 2 diabetes.

Studies were carried out in a range of countries: France (Bouche 2002; Fontvielle 1992; Kabir 2002; Taghrid 2004), Canada ( Tsihlias 2000; Wolever 1992a; Wolever 2002), Australia (Brand 1991; Heilbronn 2002; Luscombe 1999), UK (Frost 1994; Frost 1996; Frost 2004; Patel 2004), Italy (Giacco 2000), Spain (CallePascual 1988), Thailand (Komindr 2001), Denmark (Sloth 2004), Mexico (Jimenez-Cruz 2003a) and the US (Carels 2005; Raatz 2005).

\section{Intervention}

Seventeen of the 21 studies compared the effect of low GI diets with high GI diets. Three studies compared the effect of low GI diets with other diets. Of these, one study compared the effect of a low GI diet with standard diabetic dietary advice (Frost 1994), one study compared low GI and healthy eating dietary advice with healthy eating advice alone (Frost 2004), and one study compared low GI dietary advice in addition to a behavioural weight loss program with general nutritional advice as part of the same behavioural weight loss program (Carels 2005). One further study (Giacco 2000) compared low and high fibre diets but the GI of both diets was reported. In each of these studies, the GI of the diets was reported and the control diets had a higher GI than the low GI diet groups, so for the purposes of this review these comparisons have also been treated as low GI diet versus high GI diet.

In sixteen of the studies both the low and high GI diets introduced were designed to be weight maintaining by keeping energy intake constant before and after the study and between dietary groups. In a further four studies, the diets were intended to be weight reducing (Heilbronn 2002; Wolever 2002; Carels 2005; Raatz 2005). In one study, weight loss advice was given to those with a BMI over $28 \mathrm{~kg} / \mathrm{m} 2$ (Frost 2004).

The majority of the studies evaluated the effect of low GI carbohydrates in the whole diet. Three studies (Calle-Pascual 1988; Kabir 2002; Tsihlias 2000) reported the effect of substitution of low GI carbohydrates at one meal per day. Two of these studies ( Kabir 2002; Tsihlias 2000) compared the effect of high and low GI breakfasts and one study (Calle-Pascual 1988) introduced low GI foods at lunch only.

All studies included interventions over 4 weeks in length. In eleven of the studies the intervention continued for 6 weeks or less ( Bouche 2002; Calle-Pascual 1988; Fontvielle 1992; Frost 1996; Jimenez-Cruz 2003a; Kabir 2002; Komindr 2001; Luscombe 1999; Patel 2004; Taghrid 2004; Wolever 1992a). In three studies the intervention continued for 6 months (Giacco 2000; Raatz 2005; Tsihlias 2000). Some of the studies also reported outcomes at intermediate timescales throughout the study. One study reported follow-up at one year, after a 20 week intervention phase ( Carels 2005).

\section{Outcomes}

All of the studies reported major risk factors for CHD (criteria as reported previously). None of the studies reported outcomes relating to CHD mortality or morbidity, although one study did report on the length of patients hospital stay after heart surgery. Outcomes included body weight, fasting glucose, fasting insulin, total cholesterol, HDL cholesterol, LDL cholesterol, triacylglycerols, HbA1c (glycosylated haemoglobin), insulin sensitivity, insulin resistance. Some studies reported all these outcomes. Others reported only some of these outcomes.

Post-prandial glucose profiles were reported in a number of studies but have not been included as an outcome for the meta-analysis 
because the methods of measuring the outcome are different. e.g. some studies reported 3 hour Area Under a Curve data (AUC), others 9 hour AUCs.

Two studies (Bouche 2002; Sloth 2004) reported on the acceptability of the diets as a secondary outcome.

\section{Risk of bias in included studies}

\section{Overview}

All 21 studies had some methodological weaknesses according to criteria as set out in the Cochrane handbook. None fulfilled all quality criteria.

\section{Randomisation}

Of the 21 studies, only four reported an appropriate method of randomisation (Frost 1994; Frost 2004; Patel 2004; Wolever 2002). The remaining trials mentioned randomisation without describing the process. Only one study mentioned an attempt at allocation concealment (sealed envelopes were used but it is not clear if these were opaque). Baseline differences between intervention and control groups were discussed in most studies. One study did not mention randomisation in the published paper, although a crossover trial was described and confirmed by the authors (CallePascual 1988).

\section{Blinding}

One of the trials was reported to be double blinded (Kabir 2002). However, no details of the methods employed or which stage of the process was blinded were reported in the paper. None of the trials reported blinding of outcome assessors (those taking samples or carrying out laboratory tests). None of the included studies reported blinding of either the study participants or the providers of diets and this factor was not included in the criteria for quality assessment of studies for this review as it can be difficult to implement in lifestyle studies of the type included in the review.

\section{Crossover studies}

A carryover effect may occur in a crossover trial when the effects of the treatment in the first period of the trial continue over to the second period. In such cases, the results from the second period may be inaccurate. A washout period is the time when no intervention occurs between the two treatment periods and should be long enough to allow the effects from the first treatment period to completely disappear. For this review, baseline values prior to the start of the second treatment stage have been used in the metaanalysis when they have been reported in the studies. If baseline values for the second treatment phase have not been reported, the baseline values reported prior to the first treatment phase have been used.

Of the 10 crossover trials, four did not report a washout period between diet phases (Calle-Pascual 1988; Fontvielle 1992; Komindr 2001; Luscombe 1999). This means that subjects may not have started the second dietary phase with the same baseline values as the first dietary phase. None of these four studies reported intermediate baseline values between the dietary phases so whether there was a difference cannot be ascertained from the published details. In the other six studies which were of crossover design, the washout periods varied from 2 weeks to 6 weeks. Analysis has been carried out on crossover and parallel studies separately to determine if this made any difference to the overall results.

\section{Potential confounders}

All of the included studies reported body weight outcomes. The sixteen studies which designed both the low and high GI diets to be weight-maintaining reported no evidence of a difference in weight change between the diet groups. However, one of these studies specifically excluded participants if their weight varied by more than $1 \%$ between the two dietary phases (Calle-Pascual 1988). Additionally, the four studies which were designed to be weightreducing (Heilbronn 2002; Wolever 2002; Carels 2005; Raatz 2005) and one study that offered weight loss advice to those with a BMI $>28 \mathrm{~kg} / \mathrm{m} 2$ reported no evidence for a difference in weight loss between the low GI and high GI diet groups at the end of the study.

The medication status of participants in the studies varied widely. Nine studies reported that participants were taking medication. A number of trials allowed medication dosages and/or regimens to vary during the study period.

In five studies, participants were on oral hypoglycemics (sulphonylureas or metformin). In four of these studies, the level of medication for all participants remained constant throughout (Brand 1991; Kabir 2002; Komindr 2001; Luscombe 1999). In one study (Tsihlias 2000), subjects were dropped if their dose of medication changed within the first three months and their results excluded. If the change occurred after 3 months, the subjects were dropped from the study but the baseline and 3-month results were included in the analysis.

In two trials (Calle-Pascual 1988; Giacco 2000) the participants were reported to be taking insulin only. In one of these studies the dose was only changed if absolutely necessary (Giacco 2000). In the other study, patients were excluded if the insulin dose was modified during the course of the study (Calle-Pascual 1988).

In a further study in which both Type 1 and Type 2 diabetes patients were included (Fontvielle 1992), all the Type 1 patients were on insulin and allowed to change insulin doses between study periods. The Type 2 patients were on oral anti-diabetic medication and maintained on their usual therapy throughout the study. 
In one study (Wolever 2002) one high GI subject was on thiazide diuretics and one low GI subject was on beta-blockers.

One study (Heilbronn 2002) reported that those taking lipidlowering medication were requested to cease one month before the trial but made no comment about whether participants were on any oral hypoglycaemic medication. One study (Bouche 2002) reported that none of the participants were on any medication that might affect glucose, insulin or lipid metabolism.

Ten studies did not report whether participants were on medication (Carels 2005; Frost 1994; Frost 1996; Frost 2004; JimenezCruz 2003a; Patel 2004; Raatz 2005; Sloth 2004; Taghrid 2004; Wolever 1992a).

\section{Energy and macronutrient content of the diets}

In all of the studies, the energy and macronutrient content of the high and low GI diets were designed to be equivalent.

\section{Power}

Power calculations were reported as incorporated in the design of four of the 21 studies included in this review (Giacco 2000; Tsihlias 2000; Wolever 2002; Sloth 2004). The sample size of the study by Giacco (Giacco 2000) was based on $80 \%$ power to detect a difference in $\mathrm{HbA1c}$ of $>0.5 \%$ with $\mathrm{P}<0.05$. The study by Tshilias (Tsihlias 2000) was designed to have an $80 \%$ chance of detecting a difference in $\mathrm{HbA} 1 \mathrm{c}$ of $0.5 \%$ with $\mathrm{P}<0.05$. Wolever ( Wolever 2002) determined the number of subjects in each group based on $90 \%$ power to detect a difference in insulin sensitivity of $20 \%$ for $\mathrm{P}<0.05$. Power calculations made before the Sloth study (Sloth 2004) indicated that a total of 43 subjects were needed to obtain a significant $(\mathrm{P}<0.05)$ difference in body weight of $2.0 \mathrm{~kg}$ with a power of $90 \%$. One study mentioned that power calculations had been done but did not report the level of power or the difference it was designed to detect (Frost 2004). Some of the included studies were small. None of the other included studies reported power calculations. In five of the crossover studies the number of subjects studied was less than 15 (Bouche 2002; Kabir 2002; Komindr 2001; Taghrid 2004; Wolever 1992a). In one further crossover study, 36 were randomised but only 14 completed ( Jimenez-Cruz 2003a). Most of the studies reported multiple outcomes in addition to the outcomes used as the basis for power calculations.

\section{Intention to treat (ITT) analysis}

Only one of the 21 included studies reported an intention-totreat analysis along with an analysis of those compliant to diet ( Giacco 2000). However, the reported ITT analysis is considered to be inadequate because it did not incorporate data for all subjects randomised (63 subjects were randomised, but the ITT analysis only took into account data from 54 subjects and the compliantto-diet analysis incorporated data from 46 subjects).

\section{Quality assessment}

None of the studies met all of the quality assessment parameters specified for this review based on the criteria outlined in the Cochrane Reviewer's handbook and listed above in the section on 'Quality Assessment of Trials' in 'Methods of the review'. Based on these criteria all 21 of the included studies would be classified as at high risk of bias. This means that one or more quality criteria were not met. None of the studies were excluded on the basis of a low quality score as all of the 21 included studies were graded at the same level of quality based on the Cochrane criteria.

As all the trials were rated at the same level, sensitivity analysis on the basis of quality was not carried out.

\section{Effects of interventions}

As there is a large volume of data for this review (from 21 studies and for 10 different outcomes) a summary of the main results is given here, by outcome.

All graphs accompanying the original review can be accessed online (by clicking on the 'Other versions' link for the review in The Cochrane Library).

\section{Total cholesterol}

Seventeen studies reported total cholesterol. There is some evidence of a reduction in total cholesterol with low GI diets compared to high HI diets when end-of-study values were pooled from parallel studies and when parallel and crossover studies were combined. The average reduction in total choletesterol from the pooling of 17 studies was $0.16 \mathrm{mmol} / \mathrm{L}(\mathrm{P}=0.02,95 \% \mathrm{CI}-0.29$ to -0.02; Analysis 1.1). The majority of individual studies reported lower total cholesterol in the low GI group than in the high GI group, however only one individual study reported a statistically signficant effect.

When sensitivity analysis was conducted, pooling all crossover and parallel studies which substituted low GI foods at all meals there was little change when the end-of-study data was combined. The low GI diet group gave a reduction in total cholesterol of 0.17 $\mathrm{mmol} / \mathrm{L}$ compared to the high GI diet group ( $\mathrm{P}=0.02,95 \% \mathrm{CI}$ -0.32 to -0.02 ; Analysis 2.3 ). This compares with a reduction of mean total cholesterol of $0.16 \mathrm{mmol} / \mathrm{L}$ for the low GI diet compared to the high GI diet (Analysis 1.1) when all studies were included in the meta-analysis. At 4-5 weeks (Analysis 2.1) and at 12 weeks (Analysis 2.2) there was no evidence of a difference between the low GI and high GI diets.

\section{HDL cholesterol}

Sixteen studies reported HDL as an outcome. Significant heterogeneity was seen in a number of comparisons so pooling was not performed in those instances (Analysis 3.1). Almost all of the 
pooled comparisons suggested that there was no evidence of an effect of low GI diets on HDL cholesterol.

Further sensitivity analysis showed that three studies using a parallel design showed evidence of a difference between the low GI and high GI diet groups at $4-5$ weeks $(-0.11 \mathrm{mmol} / \mathrm{L}, 95 \% \mathrm{CI}-0.20$ to $-0.01, \mathrm{P}=0.03$; Analysis 4.1 ). However, the analysis was substantially weighted towards the study by Wolever 2002. This data is the only result based on change from baseline data in the analysis. At 12 weeks, significant heterogeneity was found $(\mathrm{P}<0.01)$, therefore no meta-analysis was performed (Analysis 4.2).

\section{LDL cholesterol}

Fourteen studies reported LDL cholesterol as an outcome. There is borderline evidence of a reduction in LDL cholesterol on low GI diets compared to high GI diets when data from both parallel and crossover studies at all endpoint intervals were pooled (14 studies; Analysis 5.1), and a sensitivity analysis carried out $(-0.16 \mathrm{mmol} / \mathrm{L}$, $95 \%$ CI -0.32 to $0.00, P=0.05$; Analysis 5.2). However, there is no evidence of an effect from any of the other comparisons examined.

\section{Triglycerides}

Eighteen studies reported triglycerides as an outcome. None of the comparisons detected any evidence of a difference in effect on triglycerides between the low GI and high GI diets (Analysis 6.1).

\section{Bodyweight}

Seventeen studies reported body weight as an outcome. None of the comparisons detected any evidence of a difference in effect on body weight between the low GI and high GI diets. It should be noted that in all of the studies both the low GI and high GI diets were designed to deliver equivalent energy intake (Analysis 7.1).

\section{Fasting glucose}

Seventeen studies reported fasting glucose as an outcome. While two comparisons using all the end-of study outcomes detected evidence of higher fasting glucose in low GI groups (when parallel studies alone were analysed and when both parallel and crossover studies were combined), this effect disappeared in sensitivity analyses (Analysis 8.1)

\section{Fasting insulin}

Nine studies reported fasting insulin as an outcome. None of the comparisons detected any evidence of a difference in effect on fasting insulin on low GI diets compared to high GI diets (Analysis 9.1).

\section{HbAlc (glycosylated haemoglobin)}

Twelve studies reported HbAlc as an outcome. There is little evidence of a beneficial effect of HbA1c on low GI diets compared to high GI diets from pooled analysis of 12 studies (WMD -0.09, $95 \%$ CI -0.22 to 0.04 ; Analysis 10.1). None of the studies report a significant intra-study difference between the high GI and low GI diets. However, 11 of the 12 studies do report lower HbA1c levels with low GI diets than with high GI diets.

Sensitivity analysis showed that at 12 weeks, pooled meta-analysis of four parallel studies detected no evidence of an effect on HbA1c of the low GI diet compared to the high GI diet (Analysis 10.2). When analysis was conducted without the Frost 1996 study (because of poor randomisation) there was evidence of an effect of low GI diets versus high GI diets (WMD $-0.45,95 \% \mathrm{CI}-0.82$ to -0.09; Analysis 10.3).

\section{Blood pressure}

Two studies reported blood pressure outcomes. Sloth 2004 found no significant differences (at significance level $\mathrm{P}<0.05$ ) between low GI and high GI groups in systolic (low GI $119 \mathrm{mmHg}$, SE 2; high GI $119 \mathrm{mmHg}$, SE 2) or diastolic (low GI $72 \mathrm{mmHg}$, SE 2; high GI $74 \mathrm{mmHg}$, SE 1) blood pressure after 10 weeks intervention. Frost 2004 also reported no difference between the groups in a 12 -week intervention comparing low GI diet with a higher GI healthy eating control for either systolic (low GI 135 mmHg, SE 4; high GI 136 mmHg, SE 4, $\mathrm{P}=0.7135$ ) or diastolic blood pressure (low GI $73 \mathrm{mmHg}$, SE 2; high GI $76 \mathrm{mmHg}$, SE 2, $\mathrm{P}=0.2481$.

\section{Insulin resistance/insulin sensitivity}

Three studies reported some measure of insulin resistance or insulin sensitivity. One study reported the effect of low GI diets compared to high GI diets on relative insulin resistance (HOMAR) (Sloth 2004). There was no significant difference between the low GI (1.17, SE 0.15) and high GI (1.20, SE 0.10) groups after 10 weeks. One study reported the effect on insulin sensitivity (HOMA-S) (Frost 2004). There was no significant difference $(\mathrm{P}=0.7057)$ between groups after 12 weeks in the low GI (107.73, SE 11.96) and higher GI healthy eating control group (96.10, SE 7.54). One study reported change in insulin sensitivity (HOMA). There was no difference between the low GI and high GI groups in change in insulin sensitivity (Raatz 2005). HOMA score changes over 24 weeks were 0.09 , SE 0.33 for the low GI group and 0.22 , SE 0.22 for the high GI group.

\section{Sub-group analyses on diabetic participants}

Sub-group analysis was also conducted on the studies in which the participants were diabetics at baseline for the following outcomes: total cholesterol, LDL-cholesterol, HDL-cholesterol, triglycerides, 
fasting glucose, fasting insulin, HbA1c. There was no evidence of an effect of low glycaemic index diets compared to high glycaemic diets on any of the risk factors for CHD in participants who were diabetic.

\section{Sub-group analyses on overweight participants}

Sub-group analysis was also conducted on the studies in which the participants were overweight at baseline for body weight as an outcome only. There was no evidence of an effect of low glycaemic index diets on body weight from the combined analysis of studies in which the participants were overweight at baseline.

\section{Secondary outcomes (quality of life measures)}

Only two studies reported on quality of life measures (Bouche 2002). It was reported that the subjects followed the two dietary periods (low and high GI) without any difficulty, although three out of 11 subjects noted some flatulence with the low glycaemic index diet. According to self-report, subjects lifestyles were unchanged throughout the entire study. Raatz 2005 reported no adverse effects throughout the study and that no participant withdrew from the study due to side effects or health complications.

\section{DISCUSSION}

This systematic review identified 21 randomised controlled trials of greater than 4 weeks duration, which examined the effect of low GI diets or foods compared with higher GI diets or foods on major risk factors for CHD. Major risk factors for CHD that have been examined are total cholesterol, LDL cholesterol, HDL cholesterol, triglycerides, body weight, fasting glucose, fasting insulin, glycosylated haemoglobin (HbA1c), body weight and insulin sensitivity or insulin resistance. Most of the 21 studies were short-term with 11 of the studies being of less than 6 weeks duration.

No studies were found that reported the effect of low glycaemic index diets on CHD mortality or on CHD events and morbidity. Of the 21 included studies, 11 were parallel studies and 10 were crossover studies. The crossover studies varied in quality with variations in the washout interval between the studies. Some studies reported no washout at all so there may have been baseline differences between the groups evaluated.

Data from the studies was pooled for meta-analysis at 4 weeks and at 12 weeks. As there was substantially more end-of-trial data, this was also pooled irrespective of the duration of the study. Such pooling of end-of-trial data from widely varying lengths of treatment has limitations as the size of an effect of intervention can vary with the length of the study. However, for this review it provided more data in order to determine if there was any evidence of an effect.
The poor methodological quality (according to Cochrane criteria) of most of the included studies makes overall interpretation of the data difficult. The results should be treated with caution because the methodological quality of the included studies does not meet the criteria specified in the Cochrane handbook, the trials differ widely in terms of medication regimens for participants and most of the studies are relatively small and may not have sufficient power to detect the small changes in outcomes specified. While some of the studies did report power calculations, power was usually only reported for one of the outcomes in the study. However, many of the studies reported small changes in multiple outcomes and power calculations were generally not reported for each outcome. This review has provided substantial data on which to base power calculations for the outcomes of future studies in this area.

Of particular concern is the variable reporting of risk factor outcomes. It is possible that reporting bias in selection of outcomes demonstrating favourable effects for low GI diets has occurred. It seems likely that all trials would have measured all the major outcomes (with the exception of serum insulin) specified in this review but this cannot be determined without access to the original trial protocols.

There is some evidence of a reduction in total cholesterol with low GI diets compared to high GI diets when end-of study values were pooled from parallel studies and when parallel and crossover studies were combined. The average reduction in total cholesterol of $0.16 \mathrm{mmol} / \mathrm{L}, \mathrm{P}=0.02$ (95\% CI -0.29 to -0.02$)$ is small compared with effects of statins. The majority of individual studies reported lower total cholesterol in the low GI group than in the high GI group, however, few individual studies reported a significant effect. It is not possible from the data available to determine if the lowering of total cholesterol is due to a reduction in either LDL cholesterol or HDL cholesterol. There is insufficient evidence to claim a reduction in HDL or LDL cholesterol on low GI diets. The reduction in total cholesterol is small. It is possible that an effect has only been detected on total cholesterol because there are more studies that report this outcome and that any underlying effects on LDL or HDL cholesterol are too small to be detected. From a clinical perspective, a large observational study (Stamler 2000) that examined the relationship between baseline cholesterol levels and long-term coronary and cardiovascular mortality showed a strong, continuous, independent relationship between serum cholesterol levels in young men and their long-term risk of CHD and CVD death. It also found that young men with high cholesterol levels $(>6.2 \mathrm{mmol} / \mathrm{L})$ also had an increased risk of CHD and CVD death in the short term compared to those with relatively more favourable $(<5.2 \mathrm{mmol} / \mathrm{L})$ cholesterol levels. The small changes in total cholesterol seen on low GI diets $(-0.16 \mathrm{mmol} / \mathrm{L})$ are therefore of debatable clinical relevance. The lower confidence interval of the pooled effect excludes an effect as big as a $0.29 \mathrm{mmol} / \mathrm{L}$ reduction in total cholesterol, equivalent to about a $5 \%$ reduction. None of the studies included in this review were adequately powered to 
accurately detect such small changes in cholesterol. Longer term, well-designed, high quality studies of sufficient power to detect relatively small - but clinically important - changes in cholesterol are needed to clarify if there is a clinical benefit of low GI diets on cholesterol. However, based on the data presented in this review any effect of low GI diets on CHD risk factors is small.

There is little evidence of a beneficial effect of glycosylated haemoglobin (HbA1c) on low GI diets compared to high GI diets from pooled analysis of 12 studies. None of the studies report a statistically significant intra-study difference between the high GI and low GI diets. However, 11 of the 12 studies do report lower $\mathrm{HbA1}$ c levels with low GI diets than with high GI diets. The lower 95\% confidence interval of the effect indicates that benefits of the order of a $0.22 \%$ reduction in HbAlc can be excluded. The UK Prospective Diabetes Study (UKPDS 35) study in patients with type 2 diabetes reported that any reduction in HbAlc is likely to reduce the risk of diabetic complications. Each $1 \%$ reduction in mean $\mathrm{HbAlc}$ was associated with reductions in risk of $21 \%$ for any endpoint related to diabetes, $21 \%$ for deaths related to diabetes, $14 \%$ for myocardial infarction and $37 \%$ for microvascular complications.

There were few studies included in this review that reported blood pressure or insulin sensitivity or insulin resistance. Those that did found no difference between low GI and high GI groups. None of the comparisons detected any evidence of a difference in effect on body weight between the low GI and high GI diets. This is not surprising as in all of the studies both the low GI and high GI diets were designed to deliver equivalent energy intake. Subgroup analyses on studies with diabetic participants only found no evidence of an effect of low GI diets on any risk factors for CHD. A protocol has been registered with The Cochrane Library which will examine a wider range of outcomes relevant to diabetics (Thomas 2006). For body weight as an outcome, subgroup analysis found no effect of low GI diets compared to high GI diets in studies in which participants were overweight before the study. Another Cochrane review has examined specifically the effect of glycaemic index of diets on body weight. (Thomas 2007).

It should be noted that the GI of the low and high GI diets was measured in most of the studies by, for example, food diaries. These measured values showed considerable variation. The method of measuring GI of individual foods was standardised in 1997 (FAO/ WHO 1997). However, even studies that were conducted post1997 reported marked differences in the measured GI of the low GI and high GI diets. The measured values are given in the 'characteristics of included studies' table of this review in the 'notes' section. For example, in the study by Luscombe (Luscombe 1999) the measured GI of the low GI diet was 43 units and the measured GI of the high GI diet was 63 units. In the study by Tshilias ( Tsihlias 2000) the GI of the low GI diet was 75.8, which is much higher than for the high GI diet in the Luscombe study. In other studies, the difference in measured GI of the low and high GI diets was small. For example, in one study (Wolever 2002) the low GI diet had a measured GI of 54.4 and the high GI diet had a measured GI of 59.3. All studies which compared low GI diets or foods with higher GI diets or foods have been included in this review irrespective of the actual GI of the diet.

The differences in measured GI of the diets may be due to differences in the carbohydrate content of the diets. However, there is some debate about the accurate measurement of GI in the diet. Most of the low GI diets used in the studies in this review are based on mixed meals. It has been demonstrated that the GI of mixed meals predicted by table values does not predict the measured GI and that fat and protein content, or energy content of mixed meals are more strongly correlated with the GI of mixed meals than carbohydrate content (Flint 2004). Additionally, it has been reported that most current food frequency questionnaires (FFQs) are not constructed for the purpose of measuring glycemic index and have not been validated for the measurement of glycaemic index (Barclay 2006).

Sensitivity analysis was conducted in all analyses to remove those studies which only replaced foods with low GI foods at one meal a day and pool only those studies which implemented a low GI diet at all meals 'whole-diet studies'. These sensitivity analyses had little effect on the overall results.

\section{AUTHORS' CONCLUSIONS}

\section{Implications for practice}

The evidence from controlled trials that low glycaemic index diets reduce coronary heart disease and CHD risk factors is weak. There may be a slight reduction in total cholesterol on low GI diets. Of the trials that met the review criteria, there were many poor quality studies. Many of the trials identified were short-term and conducted on small sample sizes. There is insufficient evidence that healthcare professionals should prescribe low GI diets for the purpose of reducing risk factors for CHD.

\section{Implications for research}

There is a need for well-designed, adequately powered, randomised controlled studies, of greater than 12 weeks duration to assess the usefulness of low glycaemic index diets for the reduction of coronary heart disease. This review provides data that can be used to calculate adequate power for future studies.

\section{ACKNOWLEDGEMENTS}

Margaret Burke (Cochrane Heart Group) for assistance with the development of the search strategy. 


\section{R E F E R E N C E S}

\section{References to studies included in this review}

Bouche 2002 \{published data only\}

Bouche C, Rizkalla SW, Luo J, Vidal H, Veronese A, Pacher N, et al.Five-week, low glycemic index diet decreases total fat mass and improves plasma lipid profile in moderately overweight nondiabetic men. Diabetes Care 2002;25(5):822-8.

Brand 1991 \{published data only\}

Brand JC, Colagiuri S, Crossman S, Allen A, Roberts DCK, Truswell AS. Low-glycemic index foods improve long-term glycemic control in NIDDM. Diabetes Care 1991;14(2):95-101.

Calle-Pascual 1988 \{published and unpublished data\}

Calle-Pascual AL, Gomez V, Leon E, Bordiu E. Foods with a low glycemic index do not improve glycemic control of both type 1 and type 2 diabetic patients after one month of therapy. Diabete et Metabolisme 1988;14(5):629-33.

Carels 2005 \{published data only\}

Carels RA, Darby LA, Douglass OM, Cacciapaglia HM, Rydin S. Education on the glycemic index of foods fails to improve treatment outcomes in a behavioural weight loss program. Eating Behaviours 2005;5:145-50.

\section{Fontvielle 1992 \{published data only\}}

Fontvielle AM, Rizkalla SW, Penfornis A, Acosta M, Bornet FRJ, Slama G. The use of low glycaemic index foods improves metabolic control of diabetic patients over five weeks. Diabetic Medicine 1992;9:444-50.

Frost 1994 \{published data only\}

Frost G, Wilding J, Beecham J. Dietary advice based on the glycaemic index improves dietary profile and metabolic control in type 2 diabetic patients. Diabetic Medicine 1994;11:397-401.

Frost 1996 \{published data only\}

Frost G, Keogh B, Smith D, Akinsanya K, Leeds A. The effect of low-glycemic carbohydrate on insulin and glucose response in vivo and in vitro in patients with coronary heart disease. Metabolism 1996;45(6):669-72.

Frost 2004 \{published data only\}

Frost GS, Brynes AE, Bovill-Taylor C, Dornhorst A. A prospective randomised trial to determine the efficacy of a low glycaemic index diet given in addition to healthy eating and weight loss advice in patients with coronary heart disease. European Journal of Clinical Nutrition 2004;58:121-127.

Giacco 2000 \{published data only\}

Giacco R, Parillo M, Rivellese AA, Lasorella G, Giacco A, D'Episcopo L, et al.Long-term dietary treatment with increased amounts of fiber-rich low-glycemic index natural foods improves blood glucose control and reduces the number of hypoglycemic events in type 1 diabetic patients. Diabetes Care 2000;23(10): 1461-6.

Heilbronn 2002 \{published data only\}

Heilbronn LK, Noakes M, Clifton PM. The effect of high- and lowglycemic index energy restricted diets on plasma lipid and glucose profiles in type 2 diabetic subjects with varying glycemic control. Journal of th American College of Nutrition 2002;21(2):120-7.
Jimenez-Cruz 2003a \{published data only\} Jimenez-Cruz A, Bacardi-Gascon M, Turnbull WH, Rosales G, Severino-Lugo I. A flexible, low-glycemic index mexican-style diet in overweight and obese subjects with type 2 diabetes improves metabolic parameters during a 6-week treatment period. Diabetes Care 2003;26(7):1967-70.

\section{Kabir 2002 \{published data only\}}

* Kabir M, Oppert J-M, Vidal H, Bruzzo F, Fiquet C, Wursch P, et al.Four-week low-glycemic index breakfast with a modest amount of soluble fibers in type 2 diabetic men. Metabolism 2002;51(7): 819-26.

Kabir M, Rizkalla SW, Oppert J-M, Wursch P, Bruzzo F, Slama G. Chronic effects of a low glycemic index starch breakfast on glucose and lipid metabolism in type 2 diabetic men: results of a controlled study. Diabetes 1999;48(Suppl 1):A461.

Komindr 2001 \{published data only\}

Komindr S, Ingsriswang S, Lerdvuthisopon N, Boontawee A. Effect of long-term intake of Asian food with different glycaemic indices on diabetic control and protein conservation in type 2 diabetic patients. Journal of the Medical Association of Thailand 2001;84(1): 85-97.

Luscombe 1999 \{published data only\}

Luscombe ND, Noakes M, Clifton PM. Diets high and low in glycemic index versus high monounsaturated fat diets: effects on glucose and lipid metabolism in NIDDM. European Journal of Clinical Nutrition 1999;53:473-8.

Patel 2004 \{published data only\}

Patel VC, Aldridge RD, Leeds A, Dornhorst A, Frost GS.

Retrospective analysis of the impact of a low glycaemic index diet on hospital stay following coronary artery bypass grafting: a hypothesis. Journal of Human Nutrition and Dietetics 2004;17(3): 241-7.

\section{Raatz 2005 \{published data only\}}

Raatz SK, Torkelson CJ, Redmon JB, Reck KP, Kwong CA, Swanson JE, et al.Reduced glycemic index and glycemic load diets do not increase the effects of energy restriction on weight loss and insulin sensitivity in obese men and women. Journal of Nutrition 2005;135:2387-91.

Sloth 2004 \{published data only\}

Sloth B, Krog-Mikkelson I, Flint A, Tetens I, Bjorck I, Vinoy S, et al.No difference in body weight decrease between a low-glycemicindex and a high-glycemic-index diet but reduced LDL cholesterol after 10-wk ad libitum intake of the low glycemic-index diet. American Journal of Clinical Nutrition 2004;80:337-47.

Taghrid 2004 \{published and unpublished data\} Huet D, Rizkalla SW, Rigoir A, Veronese A, Pacher N, Slama G. Metabolic effects of chronic low glycemic index diet in type 2 diabetes. Diabetes 2001;50(Suppl 2):A367.

Rizkalla SW, Taghrid L, Laromiguiere M, Huet D, Boillot J, Rigoir A, et al.Improved Plasma Glucose Control, Whole-Body Glucose Utilization, and Lipid Profile on a Low-Glycemic Index Diet in 
Type 2 Diabetic Men: A randomized controlled trial. Diabetes Care 2004;27(8):1866-72.

* Taghrid L, Rizkalla SW, Huet D, Rigoir A, Veronese A, Slama G. Improvement of glycemic control and plasma lipid levels by chronic low glycemic index diet in type 2 diabetes. Diabetes 2003;52(Suppl 1):A72.

Tsihlias 2000 \{published and unpublished data\}

Tsihlias EB, Gibbs AL, McBurney MI, Wolever TMS. Comparison of high-and low-glycemic index breakfast cereals with monounsaturated fat in the long-term dietary management of type 2 diabetes. American Journal of Clinical Nutrition 2000;72(2): $439-49$.

Wolever 1992a \{published data only\} Wolever TMS, Jenkins DJA, Vuksan V, Jenkins AL, Wong GS, Josse RG. Beneficial effect of low-glycemic index diet in overweight NIDDM subjects. Diabetes Care 1992;15(4):562-4.

Wolever 2002 \{published and unpublished data\}

* Wolever TMS, Mehling C. High carbohydrate-low glycaemic index dietary advice improves glucose disposition index in subjects with impaired glucose tolerance. British Journal of Nutrition 2002; 87:477-87.

Wolever TMS, Mehling C. Long-term effect of varying the source or amount of dietary carbohydrate on postprandial plasma glucose, insulin, triacylglycerol and free fatty acid concentrations in subjects with impaired glucose tolerance. American Journal of Clinical Nutrition 2003;77(3):612-21.

\section{References to studies excluded from this review}

\section{Abbasi 2000 \{published data only\}}

Abbasi F, McLaughlin T, Lamendola C, Kim HS, Tanaka A, Wang T, et al.High Carbohydrate Diets, Triglyceride-Rich Lipoproteins, and Coronary Heart Disease Risk. American Journal of Cardiology 2000;85:45-8.

Agus 2000 \{published data only\}

Agus MSD, Swain JF, Larson CL, Eckert EA, Ludwig DS. Dietary composition and physiologic adaptations to energy restriction. American Journal of Clinical Nutrition 2000;71(4):901-7.

Alfenas 2005 \{published data only\}

Alfenas RCG, Mattes RD. Influence of glycemic index/load on glycemic response, appetite, and food intake in healthy humans. Diabetes Care 2005;28(9):2123-9.

Bahadori 2005 \{published data only\}

Bahadori B, Yazdani-Biuki B, Krippl P, Brath H, Uitz E, Wascher TC. Low-fat, high carbohydrate (low glycaemic index) diet induces weight loss and preserves lean body mass in obese healthy subjects: results of a 24 week study. Diabetes, Obesity and Metabolism 2005; 7:290-3.

Barkoukis 2002 \{published data only\}

Barkoukis H, Fiedler KM, Lerner E. A combined high-fiber, lowglycemic index diet normalizes glucose tolerance and reduces hyperglycemia and hyperinsulinemia in adults with hepatic cirrhosis. Journal of the American Dietetic Association 2002;102: 1503-7.

Brynes 2003 \{published data only\}

Brynes AE, Edwards CM, Ghatei MA, Dornhorst A, Morgan LM, Bloom SR, et al.A randomised four-intervention crossover study investigating the effect of carbohydrates on daytime profiles of insulin, glucose, non-esterified fatty acids and triacylglycerols in middle-aged men. British Journal of Nutrition 2003;89:207-18.

Chanteleau 1985 \{published data only\}

Chanteleau E, Sonnenburg GE, Kunze K, Berger M. Importance of the glycaemic index of carbohydrate-containing foods for metabolic control of type 1 diabetics under insulin pump therapy [Die bedeutung des glykamischen index kohlenhydrathaltiger lebensmittel fur die stoffwechselkontrolle von typ 1 diabetikern unter insulinpumpen therapie]. Axthelle Ernahringrsmedizin Klinik und Praxis 1985;10:236-40.

Clapp 1998 \{published data only\}

Clapp JF. Effect of dietary carbohydrate on the glucose and insulin response to mixed caloric intake and exercise in both nonpregnant and pregnant women. Diabetes Care 1998;21:106-13.

Colagiuri 1986 \{published data only\}

Colagiuri S, Miller JJ, Holliday JL, Phelan E. Comparison of plasma glucose, serum Insulin, and C-peptide responses to three isocaloric breakfasts in non-insulin-dependant diabetic subjects. Diabetes Care 1986;9:250-5.

Collier 1986 \{published data only\} Collier GR, Wolever TMS, Wong GS, Josse RG. Prediction of glycemic response to mixed meals in noninsulin-dependant diabetic subjects. American Journal of Clinical Nutrition 1986;44:349-52.

Collier 1988 \{published data only\}

Collier GR, Giudici S, Kalmusky J, Wolever TMS, Helman G, Wesson V, et al.Low glycaemic index starchy foods improve glucose control and lower serum cholesterol in diabetic children. Diabetes, Nutrition and Metabolism - Clinical and Experimental 1988;1:11-9.

Coulston 1984 \{published data only\}

Coulston AM, Hollenbeck CB, Liu GC, Williams RA, Starich GH, Mazzaferri EL, et al.Effect of source of dietary carbohydrate on plasma glucose, insulin, and gastric inhibitory polypeptide responses to test meals in subjects with noninsulin-dependant diabetes mellitus. American Society of Clinical Nutrition 1984;40: $965-70$.

Crapo 1981 \{published data only\}

Crapo PA, Insel J, Sperling M, Kolterman OG. Comparison of serum glucose, insulin, and glucagon responses to different types of complex carbohydrate in noninsulin-dependant diabetic patients. American Journal of Clinical Nutrition 1981;34:184-90.

Dumesnil 2001 \{published data only\}

Dumesnil JG, Turgeon J, Tremblay A, Poirer P, Gilbert M, Gagnon $\mathrm{L}$, et al.Effect of a low-glycaemic Index-low-fat-high protein diet on the atherogenic metabolic risk profile of abdominally obese men. British Journal of Nutrition 2001;86:557-68.

Ebbeling 2003 \{published data only\} Ebbeling CB, Leidig MM, Sinclair KB, Hangen JP, Ludwig DS. A reduced glycemic load diet in the treatment of adolescent obesity. Archives of Pediatrics and Adolescent Medicine 2003;157:773-9.

Ebbeling 2005 \{published data only\} Ebbeling CB, Leidig MM, Sinclair KB, Seger-Shippee LG, Feldman HA, Ludwig DS. Effects of an ad libitum low glycemic load diet on cardiovascular disease risk factors in obese young adults. American Journal of Clinical Nutrition 2005;81:976-82. 
Fontvielle 1988 \{published data only\}

Fontvieille AM, Acosta M, Rizkalla SW, Bornet F, David P, Letanoux M, et al.A moderate switch from high to low glycaemicindex foods for 3 weeks improves the metabolic control of Type I (IDDM) diabetic subjects. Diabetes, Nutrition and Metabolism Clinical and Experimental 1988;1:139-43.

\section{Frost 1998a \{published data only\}}

Frost G, Leeds A, Trew G, Margara R, Dornhurst A. Insulin sensitivity in women at risk of coronary heart disease and the effect of a low glycemic diet. Metabolism 1998;47(10):1245-51.

Frost 1998b \{published data only\}

Frost GE, Keogh BE, Smith D, Leeds AR, Dornhorst A. Reduced adipocyte insulin sensitivity in Caucasian and Asian subjects with coronary heart disease. Diabetic Medicine 1998;15:1003-109.

Frost 1999b \{published data only\}

Frost G, Leeds AA, Dore CJ, Madeiros S, Brading S, Dornhurst A. Glycaemic index as a determinant of serum HDL-cholesterol concentration. Lancet 1999;353:1045-8.

\section{Fuh 1990 \{published data only\}}

Fuh MMT, Lee MMS, Jeng CY, Ma F, Chen I, Reavem GM. Effect of low fat-high carbohydrate diets in hypertensive patients with non-insulin-dependent diabetes mellitus. American Journal of Hypertension 1990;3:527-32.

Garg 1988 \{published data only\}

Garg A, Bonanome A, Grundy SM, Zhang ZU, Unger RH. Comparison of a high-carbohydrate diet with a highmonounsaturated-fat diet in patients with non-insulin-dependent diabetes mellitus. New England Journal of Medicine 1988;13: $828-35$.

Garg 1992 \{published data only\}

Garg A, Grundy SM, Unger RH. Comparison of effects of high and low carbohydrate diets on plasma lipoproteins and insulin sensitivity in patients with mild NIDDM. Diabetes 1992;41: 1278-85.

Garg 1994 \{published data only\}

Garg A, Bantle JP, Henry RR, Coulston AM, Griver KA, Raatz SK, et al.Effects of varying carbohydrate content of diet in patients with non-insulin-dependant diabetes mellitus. JAMA 1994;271:1420-9.

Gilbertson 2001 \{published data only\} Gilbertson HR, Brand-Miller JC, Thornburn AW, Evans S, Chondros P, Werther GA. The effect of flexible low glycemic index dietary advice versus measured carbohydrate exchange diets on glycemic control in children with type 1 diabetes. Diabetes Care 2001;24(7):1137-43.

Gilbertson 2003 \{published data only\} Gilbertson HR, Thornburn AW, Brand-miller JC, Chondros P, Werther GA. Effect of low glycaemic-index dietary advice on dietary quality and food choice in children with type 1 diabetes. American Journal of Clinical Nutrition 2003;77:83-90.

Golay 1992 \{published data only\}

Golay A, Koellreutter B, Bloise D, Assal JP, Wursch P. The effect of muesli or cornflakes at breakfast on carbohydrate metabolism in type 2 diabetic patients. Diabetes Research and Clinical Practice 1992;15:135-42.
Herrmann 2001 \{published data only\}

Herrmann TS, Bean ML, Black TM, Wang P, Coleman RA. High glycemic index carbohydrate diet alters the diurnal rhythm of leptin but not insulin concentrations. Experimental Biology \& Medicine 2001;226:1037-44.

Hollenbeck 1985 \{published data only\}

Hollenbeck CB, Riddle MC, Connor WE, Leklem JE. The effects of subject-selected high carbohydrate, low fat diets on glycemic control in insulin dependant diabetes mellitus. American Society for Clinical Nutrition 1985;41:293-8.

Jarvi 1995 \{published data only\}

Jarvi AE, Karlstrom BE, Granfeldt YE, Bjorck IME, Vessby BOH, Asp LN. The influence of food structure on postprandial metabolism in patients with non-insulin-dependant diabetes mellitus. American Journal of Clinical Nutrition 1995;61:837-43.

Jarvi 1999 \{published data only\} Jarvi A, Karlstrom B, Granfeldt Y, Bjorck I, Asp NG, Vessby B. Improved glycemic control and lipid profile and normalized fibrinolytic activity on a low glycemic index diet in type 2 diabetic patients. Diabetes Care 1999;22:10-8.

Jenkins 1985 \{published data only\} Jenkins DJA, Wolever TMS, Kalmusky J, Giudici S, Giordano C, Wong GS, et al.Low glycemic index carbohydrate foods in the management of hyperlipidemia. American Journal of Clinical Nutrition 1985;42:604-17.

Jenkins 1987a \{published data only\} Jenkins DJA, Wolever TMS, Collier GR, Ocana A, Rao AV, Buckley G, et al.Metabolic effects of a low-glycemic-index diet. American Society for Clinical Nutrition 1987;46:968-75.

Jenkins 1987b \{published data only\} Jenkins DJA, Wolever TMS, Kalmusky J, Guidici S, Giordano C, Patten R, et al.Low glycemic index diet in hyperlipidemia: use of traditional starchy foods. American Journal of Clinical Nutrition 1987;46:66-71.

Jenkins 1988 \{published data only\} Jenkins DJA, Wolever TMS, Buckley G, Lam KY, Giudici S, Kalmusky J, et al.Low glycemic index starchy foods in the diabetic diet. American Journal of Clinical Nutrition 1988;48:248-54.

Jenkins 2002a \{published data only\}

Jenkins DJA, Kendall CWC, Augustin LSA, Martini MC, Axelsen M, Faulkner D, et al.Effect of wheat bran on glycemic control and risk factors for cardiovascular disease in type 2 diabetes. Diabetes Care 2002;25:1522-8.

Jenkins 2002b \{published data only\} Jenkins AL, Jenkins DJA, Zdravkovic U, Wursch P, Vuksan V. Depression of the glycemic index by high levels of B-glucan fiber in two functional foods tested in type 2 diabetes. European Journal of Clinical Nutrition 2002;56:622-8.

Jeppesen 1997 \{published data only\}

Jeppensen J, Schaaf P, Jones C, Zhou MY, Chen IYD, Reaven GM. Effects of low-fat, high-carbohydrate diets on risk factors for ischemis heart disease in postmenopausal women. American Society for Clinical Nutrition 1997;65:1027-33.

Jiminez-Cruz 2003b \{published data only\} Jiminez-Cruz A, Seimandi-Mora H, Bacardi-Gascon M. Effect of low glycemic index diet in hyperlipidemia [Efecto de dietas con 
bajo indice glucemico en hiperlipidemicos]. Nutricion Hospitalaria 2003;18(6):331-5.

\section{Jiminez-Cruz 2004 \{published data only\}}

Jiminez-Cruz A, Turnbull WH, Bacardi-Gascon MB, RosalesGaray P. A high fiber, moderate-glycemic index, Mexican style diet improves dyslipidemia in individuals with type 2 diabetes. Nutrition Research 2004;24(1):19-27.

\section{Kiens 1996 \{published data only\}}

Kiens B, Richter EA. Types of carbohydrate in an ordinary diet affect insulin action and muscle substrates in humans. American Journal of Clinical Nutrition 1996;63:47-53.

\section{Lafrance 1998 \{published data only\}}

Lafrance L, Rabasa-Lhoret R, Poisson D, Ducros F, Chiasson J-L. The effects of different glycaemic index foods and dietary fibre intake on glycaemic control in type 1 diabetic patients on intensive insulin therapy. Diabetic Medicine 1998;15:972-8.

\section{LaHaye 2005 \{published data only\}} LaHaye SA, Hollett PM, Vyselaar JR, Shakchi M, Lahey KA, Day AG. Comparison between a low glycemic load diet and a Canada Food Guide diet in cardiac rehabilitation patients in Ontario. Canadian Journal of Cardiology 2005;21(6):489-94.

Laitinen 1993 \{published data only\}

Laitinen JH, Ahola IE, Sarkkinen ES, Winberg RL, HarmaakorpiIIvonen PA, Uusitupa MI. Impact of intensified dietary therapy on energy and nutrient intakes and fatty acid composition of serum lipids in patients with recently diagnosed non-insulin-dependant diabetes mellitus. Diabetes Spectrum 1995;8:102-3.

\section{Leinonen 2000 \{published data only\}}

Leinonen KS, Poutanen KS, Mykkanen HM. Rye bread decreases serum total and LDL cholesterol in men with moderately elevated serum cholesterol. Journal of Nutrition 2000;130:164-70.

Lerman-Garber 1995 \{published data only\} Lerman-Garber I, Gulias-Herrero A, Palma ME, Valles VE, Guerrero LA, Garcia EG, et al.Response to high carbohydrate and high monounsaturated fat diets in hypertriglyceridemic non-insulin dependent diabetic patients with poor glycemic control. Diabetes, Nutrition and Metabolism - Clinical and Experimental 1995;8: $339-45$.

Lieberman 2003 \{published data only\}

Lieberman S. Natural methods for accelerating weight loss: The low glycemic index diet, green tea, chromium, and 5hydroxytryptophan. Alternative and Complementary Therapies 2003;9(6):307-11.

\section{Liu 2000 \{published data only\}}

Liu S, Willett WC, Stampfer MJ, Hu FB, Franz M, Sampson L, et al.A prospective study of dietary glycemic load, carbohydrate intake and risk of coronary heart disease in US women. American Journal of Clinical Nutrition 2000;71(6):1455-61.

Liu 2002a \{published data only\}

Liu S, Manson JE, Buring JE, Stampfer MJ, Willett WC, Ridker PM. Relation between a diet with a high glycemic load and plasma concentrations of high-sensitivity C-reactive protein in middle-aged women. American Journal of Clinical Nutrition 2002;75(3):492-8.
Ludwig 1999 \{published data only\}

Ludwig DS, Majzoub JA, Al-Zahrani A, Dallal GE, Blanco I, Roberts SB. High glycemic index foods, overeating, and obesity. Pediatrics 1999;103(3):E26.

\section{Lunetta 1996 \{published data only\}}

Lunetta M, Mauro MD. Different effect of acute and chronic oral metformin administration on glucose and insulin response to bread and to pasta in non-insulin dependent diabetic patients. Diabetes Research and Clinical Practice 1996;33:53-8.

Morales 1997 \{published data only\}

Morales LM, Semprun-Fereira M, Ryder E, Valbuena H, Rincon E, Fernandez V, et al.Improved triglyceride control with low glycaemic index-high carbohydrate modified-lipid diet in a hypertriglyceridaemic child. Acta Paediatrica 1997;86:772-4.

Pacy 1984 \{published data only\}

Pacy PJ, Dodson PM, Kubicki AJ, Fletcher RF, Taylor KG. Effect of a high fibre, high carbohydrate dietary regimen on serum lipids and lipoproteins in type II hypertensive diabetic patients. Diabetes Research 1984;1:159-63.

Percheron 1997 \{published data only\} Percheron C, Colette C, Avignon A, Monnier L. Metabolic responses to high carbohydrate breakfasts in obese patients with impaired glucose tolerance. Comparison of meals containing dairy products and fruits versus bread. Nutrition Research 1997;17: 797-806.

Pereira 2002 \{published data only\}

Pereira MA, Jacobs DR, Pins JJ, Raatz SK, Gross MD, Slavin JL, et al.Effext of whole grains on insulin sensitivity in overweight hyperinsulinemic adults. American Journal of Clinical Nutrition 2002;75(5):848-55.

Pereira 2004 \{published data only\}

Pereira MA, Swain J, Goldfine AB, Rifai N, Ludwig DS. Effects of a low glycemic index load diet on resting energy expenditure and heart disease risk factors during weight loss. JAMA 2004;292(20): 2482-90.

Pittas 2005 \{published data only\}

Pittas AG, Das SK, Hajduk CL, Golden J, Saltzman E, Stark PC, et al.A low glycemic load diet facilitates greater weight loss in overweight adults with high insulin secretion but not in overweight adults with low insulin secretion in the CALERIE trial. Diabetes Care 2005;28(12):2939-41.

Poppitt 2002 \{published data only\}

Poppitt SD, Keogh GF, Prentice AM, Williams DEM, Sonnemans HMW, Valk EEJ, et al.Long-term effects of ad libitum low-fat, high-carbohydrate diets on body weight and serum lipids in overweight subjects with metabolic syndrome. American Society for Clinical Nutrition 2002;75:11-20.

\section{Rabasa-Lhoret 1999 \{published data only\}}

Rabasa-Lhoret R, Garon J, Langelier H, Poisson D, Chiasson JL. Effects of meal carbohydrate content on insulin requirements in type 1 diabetic patients treated intensively with the basal-bolus (ultralente- regular) insulin regimen. Diabetes Care 1999;22: $667-73$.

Rasmussen 1993 \{published data only\}

Rasmussen OW, Thomsen C, Hansen KW, Vesterlund M, Winther E, Hermansen K. Effects on blood pressure, glucose, and lipid levels 
of a high-monounsaturated fat diet compared with a highcarbohydrate diet in NIDDM subjects. Diabetes Care 1993;16: 1564-71.

Salmeron 1997 \{published data only\}

Salmeron J, Ascherio A, Rimm EB, Colditz GA, Spiegelman D, Jenkins DJ, et al.Dietary fiber, glycemic load, and risk of NIDDM in men. Diabetes Care 1997;20(4):545-50.

Santacroce 1990 \{published data only\}

Santacroce G, Forlani G, Giangiulio S, Galuppi V, Pagani M, Vannini P. Long-term effects of eating sucrose on metabolic control of type 1 (insulin-dependent) diabetic outpatients. Acta Diabetologica Latina 1990;27:365-70.

Scholz 2003 \{published data only\}

Scholz S, Chantelau E. Glycemic index and insulin dosage on intensive insulin therapy [Glykamischer index und insulindosierung bei intensivierter insulin-therapie]. Interistische Praxis 2003;43(2):389-96.

\section{Sciarrone 1993 \{published data only\}}

Sciarrone SEG, Martin T, Strahan LJ, Beilin VB, Burke V, Rogers P, et al.Ambulatory blood pressure and heart rate responses to vegetarian meals. Journal of Hypertension 1993;11:227-85.

Sharafetdinov 1997 \{published data only\}

Sharafetdinov KhKh, Meshcheriakova VA, Plotnikova OA. Change in postprandial glycemia as affected by various carbohydratecontaining products in patients with type II diabetes mellitus [Izmenenie poslepishchevoi glikemii pod vliianiem nekotorykh uglevodsoderzhashchikh produktov u bol'nykh sakharnym diabetom II tipa]. Voprosny Pitania 1997;1:27-30.

Singh 1991 \{published data only\}

Singh RB, Rastogi SS, Sircar AR, Mehta PJ, Sharma KK. Dietary strategies for risk factor modification to prevent cardiovascular diseases. Nutrition 1991;7:210-15.

Slabber 1994 \{published data only\} Slabber M, Barnard HC, Kuyl JM, Dannhauser A, Schall R. Effects of a low-insulin response, energy restricted diet on weight loss and plasma insulin concentrations in hyperinsulinemic obese females. American Journal of Clinical Nutrition 1994;60:48-53.

Spieth 2000 \{published data only\}

Spieth LE, Harnish JD, Lenders CM, Raezer LB, Pereira MA, Hangen SJ, et al.A low glycemic index diet in the treatment of pediatric obesity. Archives of Pediatrics and Adolescent Medicine 2000;154:947-51.

Van Horn 1991 \{published data only\}

Van Horn L, Moag-Stahlberg A, Liu K, Ballew C, Ruth K, Hughes $\mathrm{R}$, et al.Effects on serum lipids of adding instant oats to usual American diets. American Journal of Public Health 1991;81(2): $183-4$.

Wolever 1992b \{published data only\}

Wolever TMS, Jenkins DJA, Vuksan V, Jenkins AL, Wong GS, Josse RG. Beneficial effect of low-glycaemic index diet in type 2 diabetes. Diabetic Medicine 1992;9:451-8.

Wolever 1995 \{published data only\}

Wolever T, Bentum-Williams Am, Jenkins DJA. Physiological modulation of plasma free fatty acid concenrations by diet: metabolic implications in nondiabetic subjects. Diabetes Care 1995; 18:962-70.

Yang 2002 \{published data only\}

Yang EJ, Chung HK, Kim WY, Kerver JM, Song WO.

Carbohydrate intake is associated with diet quality and risk factors for cardiovascular disease in US adults: NHANES III. Journal of the American College of Nutrition 2002;22:71-9.

\section{Additional references}

Barclay 2005

Barclay AW, Brand-Miller JC, Wolever, TMS. Glycemic index, glycemic load and glycemic response are not the same. Diabetes Care 2005;28(7):1839.

Barclay 2006

Barclay AW, Brand-Miller JC. Validity of glycemic index estimates in the insulin resistance atherosclerosis study. Diabetes Care 2006; 29(7):1718.

\section{Bornet 1987}

Bornet FR, Costagliola D, Rizkalla SW, Blayo A, Fontvielle AM, Haardt MJ, et al.Insulinemic and glycemic indexes of six starch-rich foods taken alone and in a mixed meal by type 2 diabetics.

American Journal of Clinical Nutrition 1987;45:588-95.

\section{Brand-Miller 2002}

Brand-Miller JC, Holt SHA, Pawlak DB, McMillan J. Glycemic index and obesity. American Journal of Clinical Nutrition 2002;76 (1):281S-5S

Brand-Miller 2003

Brand-Miller J, Hayne S, Petocz P, Colagiuri S. Low-glycemic index diets in the management of diabetes: a meta-analysis of randomized controlled trials. Diabetes Care 2003;26(8):2466-8.

Carter 1999

Carter M, Moser K, Kelly S. Health of older people: disease prevalence, prescription and referral rates, England and Wales, 1996. Health Statistics Quarterly 1999, (Winter):9-15.

\section{Cochrane 2002}

Cochrane Collaboration Open Learning Material (Module A1),

Version 1.1. http://www.cochrane-net.org/openlearning/HTML/ modA1-6.htm Nov 2002.

Coulston 1987

Coulston AM, Hollenbeck CB, Swislocki AL, Reaven GM. Effect of source of dietary carbohydrate on plasma glucose and insulin responses to mixed meals in subjects with NIDDM. Diabetes Care 1987; 10:395-400.

\section{DoH 2001}

Department of Health. National service framework for diabetes: standards. http://www.dh.gov.uk/PolicyAndGuidance/

HealthAndSocialCareTopics/Diabetes/fs/en (Accessed 2004) 2001.

FAO/WHO 1997

FAO/WHO Expert Committee. Carbohydrates in human nutrition (FAO Food and Nutrition Paper - 66) (Expert consultation 1997 Apr : Rome). FAO, 1998.

Ferrannini 1991

Ferrannini E, Haffner SM, Mitchell BD, Stern MP.

Hyperinsulinaemia: The key feature of a cardiovascular and metabolic syndrome. Diabetologia 1991;34:416-22. 


\section{Flint 2004}

Flint A, Moller BK, Raben A, Pedersen D, Tetens I, Holst JJ, et al.The use of glycaemic index tables to predict glycaemic index of composite breakfast meals. British Journal of Nutrition 2004;91: 979-89.

\section{Ford 2001}

Ford ES, Liu S. Glycemic index and serum high density lipoprotein cholesterol concentration among US adults. Archives of Internal Medicine 2001;161:572-6.

\section{Foster-Powell 1995}

Foster-Powell K, Miller JB. International tables of glycaemic index. American Journal of Clinical Nutrition 1995;62(4):871S-90S.

\section{Foster-Powell 2002}

Foster-Powell K, Holt SH, Brand-Miller JB. International tables of glycemic index and glycemic load values. American Journal of Clinical Nutrition 2002;76:5-56.

\section{Frost 2000}

Frost G, Dornhorst A. The relevance of the glycaemic index to our understanding of dietary carbohydrates. Diabetic Medicine 2000; 17:336-45.

\section{JAMA 2004}

JAMA. Author Instructions: Système International (SI) Conversion Factors for Selected Laboratory Components. http://jama.amaassn.org/misc/auinst' si.dtl [accessed on 19 July 2004] 2004.

\section{Jenkins 1981}

Jenkins D, Wolever T, Taylor H, Barker H, Fielden H, Baldwin AM, et al.Glycemic index of foods. A physiological basis for carbohydrate exchange. American Journal of Clinical Nutrition 1981;34:362-6.

Leeds 2002

Leeds AR. Glycemic index and heart disease. American Journal of Clinical Nutrition 2002;76(1):286S-9S.

\section{Murray 1997}

Murray CLJ, Lopez AD. Mortality by cause for eight regions of the world: Global Burden of Disease. Lancet 1997;349:1269-76.

\section{OHE 1999}

Office of Health Economics. OHE Compendium of Health Statistics. London: Office of Health Economics, 1999.

\section{Reaven 1993}

Reaven GM. Role of insulin resistance in human disease (syndrome X): an expanded definition. Annual Review of Medicine 1993;44: 121-31.

\section{Rizkalla 2002}

Rizkalla SW, Bellisle F, Slama G. Health benefits of low glycaemic index foods, such as pulses, in diabetic patients and healthy individuals. British Journal of Nutrition 2002;88(Suppl 3): S255-S262.

\section{Schulz 1995}

Schulz KF, Chalmers I, Hayes RJ, Altman DG. Empirical evidence of bias. Dimensions of methodological quality associated with estimates of treatment effects in controlled trials. Journal of the American Medical Association 1995;273(5):408-12.

\section{Sheard 2004}

Sheard NF, Clark NG, Brand-Miller JC, Franz MJ, Pi-Sunyer FX, Mayer-Davis E, et al.Dietary carbohydrate (amount and type) in the prevention and management of diabetes: a statement by the American Diabetes Association. Diabetes Care 2004;27:2266-71.

\section{Stamler 2000}

Stamler J, Daviglus ML, Garside DB, et al.Relationship of baseline serum cholesterol levels in 3 large cohorts of younger men to longterm coronary, cardiovascular, and all-cause mortality and to longevity. JAMA 2000;284:311-8.

\section{Thomas 2006}

Thomas DE, Elliot EJ. Low glycaemic index, or low glycaemic load, diets for diabetes mellitus. Cochrane Database of Systematic Reviews 2006, Issue 4. [DOI: 10.1002/14651858.CD006296]

\section{Thomas 2007}

Thomas DE, Elliot EJ, Baur L. Low glycaemic index, or low glycaemic load, diets for overweight and obesity (Review). Cochrane Database of Systematic Reviews 2007, Issue 3.

\section{UKPDS 35}

Stratton IM, Adler AI, Neil AW, Matthews DR, Manley SE, Cull $\mathrm{CA}$, et al.Association of glycaemia with macovascular and microvascular complications of type 2 diabetes (UKPDS 35): prospective observational study. BMJ 2000;321:405-12.

\section{Wolever 1985}

Wolever TM, Jenkins DJ. Application of glycaemic index to mixed meals [letter]. Lancet 1985;2:944.

\section{Wolever 1986}

Wolever TM, Jenkins DJ. The use of the glycemic index in predicting the blood glucose response to mixed meals. American Journal of Clinical Nutrition 1986;43:167-72.

\section{Wolever 1988}

Wolever TM, Jenkins DJ, Collier GR, Lee R. Metabolic response to test meals containing different carbohydrate foods. 1. Relationship between rate of digestion and plasma insulin. Nutrition Reviews 1988;8:573-81.

\section{Wolever 1990}

Wolever TM. The glycaemic index. World Review in Nutrition and Dietetics 1990;62:120-85.

* Indicates the major publication for the study 
CHARACTERISTICS OF STUDIES

\section{Characteristics of included studies [ordered by study ID]}

Bouche 2002

\begin{tabular}{|c|c|}
\hline Methods & $\begin{array}{l}\text { Study design: Randomised crossover study } \\
\text { Random allocation: Unclear } \\
\text { Allocation concealment: Unclear } \\
\text { Blinding of outcome assessors: Unclear } \\
\text { Length of intervention: } 5 \text { weeks } \\
\text { Unit of allocation: Participant } \\
\text { Unit of analysis: Participant } \\
\text { Protection against contamination: Unclear } \\
\text { Intention-to-treat analysis: Not done }\end{array}$ \\
\hline Participants & $\begin{array}{l}\text { Diagnosis of CHD or risk factors: Overweight } \\
\text { Exclusion criteria: Abnormal renal, hepatic or thyroid function } \\
\text { Medications used: None that might affect glucose, insulin or lipid metabolism } \\
\text { Smoking status: Not reported } \\
\mathrm{n}=11 \text { randomised, } 11 \text { completed } \\
\text { Mean age: } 46+/-3 \text { (SE) (mean age) } \\
\text { Male/female ratio: all male } \\
\text { Baseline characteristics: Reported } \\
\text { Geographical location: France }\end{array}$ \\
\hline
\end{tabular}

Interventions

Intervention: Low GI diet . In the low GI period, carbohydrate items with a GI< $45 \%$ were recommended. Over a run-in period of 15 days subjects received individual counseling by a dietitian. Dietary intake was prescribed individually according to data from dietary questionnaires ( 3 day recall).

Comparison interventions: High GI diet . In the high GI period, foods with a GI > 60\% were recommended. Prescribed individually, as for Low GI diet.

Washout interval (for crossover studies) : 5 weeks.

Assessment of dietary compliance: Patients were asked to complete a food diary on the last 7 days of each dietary period.

Comparison of total energy and macronutrient intakes: Reported

\begin{tabular}{ll}
\hline Outcomes & Main outcomes: \\
& Fasting plasma glucose, body weight, glycosylated haemoglobin, Fasting plasma cholesterol, LDL-choles- \\
terol, plasma triglycerides & Other outcomes: \\
Urinary glucose, very-low density lipoprotein triglycerides and cholesterol, HDL cholesterol subfractions, \\
8-hr profiles of plasma glucose, insulin, C-peptide and triglycerides \\
\hline
\end{tabular}

Notes $\quad$ Reported GI of diets: Low GI diet $41.0+/-1 \%$, High GI diet $71.3+/-1.3 \%$.

Risk of bias

Item

Authors' judgement

Description 
Bouche 2002 (Continued)

\begin{tabular}{|c|c|}
\hline Allocation concealment? & B - Unclear \\
\hline \multicolumn{2}{|l|}{ Brand 1991} \\
\hline Methods & $\begin{array}{l}\text { Study design: Randomised crossover study } \\
\text { Random allocation: Unclear } \\
\text { Allocation concealment: Unclear } \\
\text { Blinding of outcome assessors: Unclear } \\
\text { Length of intervention: } 12 \text { weeks } \\
\text { Unit of allocation: Participant } \\
\text { Unit of analysis: Participant } \\
\text { Protection against contamination: Unclear } \\
\text { Intention-to-treat analysis: Not done }\end{array}$ \\
\hline Participants & $\begin{array}{l}\text { Diagnosis of CHD or risk factors: Subjects with well-controlled non-insulin dependent diabetes } \\
\text { Exclusion criteria: Those on any medication other than oral hypoglycaemic agents } \\
\text { Medications used: } 10 / 16 \text { subjects were taking oral hypoglycaemic agents (sulphonylureas). Medication } \\
\text { was not altered during the study. } \\
\text { Smoking status: Not reported } \\
\mathrm{n}=16 \text { randomised, } 16 \text { completed } \\
\text { Mean age: } 62+/-9 \text { (SD) years (mean age) } \\
\text { Male/female ratio: } 62 \% / 38 \% \\
\text { Baseline characteristics: Reported } \\
\text { Geographical location: Australia }\end{array}$ \\
\hline
\end{tabular}

Interventions Intervention: Low GI diet . Before the study and then at weekly intervals throughout both dietary periods, the subjects were given dietary counseling in their own homes. Each diet was prescribed individually according to data obtained from a 4-day weighed record to maintain constant energy intake and nutrient proportions.

Comparison interventions: High GI diet, prescribed individually as for Low GI diet.

Washout interval (for crossover studies) : 3 weeks

Assessment of dietary compliance: 4-day (Wed-Sat) weighed food record made at the completion of each dietary period.

Comparison of total energy and macronutrient intakes: Reported

\begin{tabular}{ll} 
Outcomes & $\begin{array}{l}\text { Main outcomes: } \\
\text { Fasting plasma glucose, Fasting plasma insulin, Fasting total cholesterol, HDL-cholesterol, LDL-choles- } \\
\text { terol, Fasting triacylglycerols, Body weight } \\
\text { Other outcomes: } \\
\text { Total fat mass, postprandial plasma glucose and insulin profiles and AUCs, fructosamine, plasma leptin, } \\
\text { hepatic glucose production, insulin secretion and sensitivity, gene expression of genes involved } \\
\text { in adipocyte differentiation and lipid metabolism. }\end{array}$ \\
\hline Notes & Reported GI of diets: Low GI diet $77+/-3$ (mean), High GI diet $90+/-1$ (mean). \\
\hline
\end{tabular}

Risk of bias

\begin{tabular}{|c|c|c|}
\hline Item & Authors' judgement & Description \\
\hline
\end{tabular}

Copyright (@) 2008 The Cochrane Collaboration. Published by John Wiley \& Sons, Ltd. 
Brand 1991 (Continued)

\begin{tabular}{|c|c|c|}
\hline Allocation concealment? & Unclear & B - Unclear \\
\hline
\end{tabular}

\section{Calle-Pascual 1988}

\begin{tabular}{|c|c|c|}
\hline Methods & \multicolumn{2}{|c|}{$\begin{array}{l}\text { Study design: Randomised crossover study } \\
\text { Random allocation: Unclear } \\
\text { Allocation concealment: Unclear } \\
\text { Blinding of outcome assessors: Unclear } \\
\text { Length of intervention: } 4 \text { weeks } \\
\text { Unit of allocation: Participant } \\
\text { Unit of analysis: Participant } \\
\text { Protection against contamination: Unclear } \\
\text { Intention-to-treat analysis: Not done }\end{array}$} \\
\hline Participants & \multicolumn{2}{|c|}{$\begin{array}{l}\text { Diagnosis of CHD or risk factors: Diabetes (Type } 1 \text { and type } 2 \text { ) } \\
\text { Exclusion criteria: If HbA1c not stable over past } 4 \text { months) } \\
\text { Medications used: All patients were treated with insulin. Patients were excluded If insulin dose was } \\
\text { modified during the course of the study. } \\
\text { Smoking status: Not reported } \\
\mathrm{n}=34 \text { randomised, } 24 \text { completed } \\
\text { Mean age: Type } 1 \text { patients } 25+/-4 \text { (SD) years, Type } 2 \text { patients } 59+/-8 \text { (SD) years. } \\
\text { Male/female ratio: not reported } \\
\text { Baseline characteristics: Not reported } \\
\text { Geographical location: Spain }\end{array}$} \\
\hline Interventions & \multicolumn{2}{|c|}{$\begin{array}{l}\text { Intervention: Low GI carbohydrates at lunch. Patients were given a diet with a high carbohydrate }(60 \%) \text {, } \\
\text { low fat ( } 20 \%) \text { content with } 25 \% \text { of carbohydrates supplied at lunch in the form of } 5 \text { foods with GI ranged } \\
\text { between } 29 \text { and } 36 \text {. } \\
\text { Comparison interventions: High GI carbohydrates at lunch. Patients were given a diet with a high car- } \\
\text { bohydrate ( } 60 \%) \text {, low fat ( } 20 \%) \text { content with } 25 \% \text { of carbohydrates supplied at lunch in the form of } 5 \\
\text { foods with GI ranged between } 50 \text { and } 92 \text {. } \\
\text { Washout interval (for crossover studies) : None reported } \\
\text { Assessment of dietary compliance: Not reported } \\
\text { Comparison of total energy and macronutrient intakes: Reported }\end{array}$} \\
\hline Outcomes & \multicolumn{2}{|c|}{$\begin{array}{l}\text { Main outcomes: } \\
\text { glycosylated haemoglobin. } \\
\text { Other outcomes: postprandial glucose }\end{array}$} \\
\hline Notes & \multicolumn{2}{|c|}{$\begin{array}{l}\text { Reported GI of individual low GI carbohydrates supplied at lunch ranged between } 29 \text { and } 36 \text {. GI of } \\
\text { individual high GI carbohydrates supplied at lunch ranged between } 29 \text { and } 36 \text {. }\end{array}$} \\
\hline \multicolumn{3}{|l|}{ Risk of bias } \\
\hline Item & Authors' judgement & Description \\
\hline Allocation concealment? & Unclear & B - Unclear \\
\hline
\end{tabular}




\begin{tabular}{|c|c|c|}
\hline Methods & \multicolumn{2}{|c|}{$\begin{array}{l}\text { Study design: Parallel RCT } \\
\text { Random allocation: Unclear } \\
\text { Allocation concealment: Unclear } \\
\text { Blinding of outcome assessors: Unclear } \\
\text { Length of intervention: } 20 \text { weeks (with follow-up after } 1 \text { year) } \\
\text { Unit of allocation: Participant } \\
\text { Unit of analysis: Participant } \\
\text { Protection against contamination: Unclear } \\
\text { Intention-to-treat analysis: Not done }\end{array}$} \\
\hline Participants & \multicolumn{2}{|c|}{$\begin{array}{l}\text { Diagnosis of CHD or risk factors: Obese subjects }(\mathrm{BMI}>30 \mathrm{~kg} / \mathrm{m} 2) \\
\text { Exclusion criteria: Cardiovascular disease, musculoskeletal problems, insulin-dependent diabetes or un } \\
\text { controlled Type } 2 \text { diabetes, elevated resting blood pressure }(>100 \mathrm{~mm} \mathrm{Hg}) \text {. } \\
\text { Smoking status: Smokers were excluded. } \\
\mathrm{n}=53 \text { randomised, } 38 \text { completed } \\
\text { Mean age: Control group } 43.5(\mathrm{SD}=9.83) \text { GI group } 43.2(\mathrm{SD}=9.02) \text { years } \\
\text { Male/female ratio: Control (BWLP) } 88.5 \% \text { female, GI group }(\mathrm{BWLP}+\mathrm{GI}) 77.8 \% \text { female. } \\
\text { Baseline characteristics: Reported } \\
\text { Geographical location: USA }\end{array}$} \\
\hline Interventions & \multicolumn{2}{|c|}{$\begin{array}{l}\text { Intervention: Behavioural weight loss program and low GI diet. BWLP as detailed below with the addition } \\
\text { of GI education with emphasis on a low-fat, low GI diet. } \\
\text { Comparison interventions: Behavioural weight loss program only (BWLP). The program is a weight } \\
\text { management program aimed at chieving gradual weight loss, increasing physical activity and reducing } \\
\text { energy and fat intake. Nutritional information was generally consistent with the GI education program } \\
\text { but included only limited discussion of carbohydrates and no reference to GI or GI related constructs. } \\
\text { Assessment of dietary compliance: 4-day food records at baseline and posttreatment. } \\
\text { Comparison of total energy and macronutrient intakes: Reported }\end{array}$} \\
\hline Outcomes & \multicolumn{2}{|l|}{$\begin{array}{l}\text { Main outcomes: } \\
\text { Body weight } \\
\text { Other outcomes: } \\
\text { BMI, body fat }\end{array}$} \\
\hline Notes & \multicolumn{2}{|c|}{$\begin{array}{l}\text { Reported GI of diets (at posttreatment): BWLP +GI } 51.5 \text { (SD=4.7) (mean), Control BWLP only } 56.5 \\
(\mathrm{SD}=4.3) \text { (mean). }\end{array}$} \\
\hline \multicolumn{3}{|l|}{ Risk of bias } \\
\hline Item & Authors' judgement & Description \\
\hline Allocation concealment? & Unclear & B - Unclear \\
\hline
\end{tabular}


Fontvielle 1992

\begin{tabular}{|c|c|c|}
\hline Methods & \multicolumn{2}{|c|}{$\begin{array}{l}\text { Study design: Randomised crossover study } \\
\text { Random allocation: Unclear } \\
\text { Allocation concealment: Unclear } \\
\text { Blinding of outcome assessors: Unclear } \\
\text { Length of intervention: } 5 \text { weeks } \\
\text { Unit of allocation: Participant } \\
\text { Unit of analysis: Participant } \\
\text { Protection against contamination: Unclear } \\
\text { Intention-to-treat analysis: Not done }\end{array}$} \\
\hline Participants & \multicolumn{2}{|c|}{$\begin{array}{l}\text { Diagnosis of CHD or risk factors: Subjects with well-controlled diabetes (12 Type } 1,6 \text { Type } 2 \text { ) } \\
\text { Exclusion criteria: Not reported } \\
\text { Medications used: All } 12 \text { Type } 1 \text { patients were on insulin and allowed to change their insulin doses between } \\
\text { study periods. } \\
\text { All } 6 \text { Type } 2 \text { patients were treated with oral anti-diabetic drugs and maintained on their usual therapy } \\
\text { over both study periods. } \\
\text { Smoking status: Not reported } \\
\mathrm{n}=18 \text { randomised, } 18 \text { completed } \\
\text { Mean age: All subjects }=47.2+/-11.6 \text { (SD) (Type } 1=42.7+/-10.3 \text { (SD), Type } 2=56.3+/-8.4) \\
\text { Male/female ratio: } 66.7 \%: 33.3 \% \\
\text { Baseline characteristics: Not reported } \\
\text { Geographical location: France }\end{array}$} \\
\hline Interventions & \multicolumn{2}{|c|}{$\begin{array}{l}\text { Intervention: Low GI diet . Each diet was prescribed individually according to data obtained from a } \\
\text { baseline diet inquiry ( } 7 \text {-day recall technique)to maintain the initial energy intake and nutrient proportions } \\
\text { constant throughout the study. } \\
\text { Comparison interventions: High GI diet, prescribed individually as for Low GI diet. } \\
\text { Washout interval (for crossover studies) : none reported } \\
\text { Assessment of dietary compliance: 7-day food diary made at the completion of each dietary period. } \\
\text { Comparison of total energy and macronutrient intakes: Reported }\end{array}$} \\
\hline Outcomes & \multicolumn{2}{|c|}{$\begin{array}{l}\text { Main outcomes: } \\
\text { Fasting plasma glucose, fasting blood glucose, total plasma cholesterol, plasma HDL-cholesterol,plasma } \\
\text { triglycerides, glycosylated haemoglobin, body weight } \\
\text { Other outcomes: } \\
\text { Insulin dose, postprandial blood glucose, mean blood glucose, fructosamine, phospholipids, apolipopro- } \\
\text { tein A1, apolipoprotein B, insulin binding to erythrocytes. }\end{array}$} \\
\hline Notes & \multicolumn{2}{|c|}{ Reported GI of diets: Low GI diet $38.1+/-5.3 \%$ (mean), High GI diet $64.2+/-3.1 \%$ (mean). } \\
\hline \multicolumn{3}{|l|}{ Risk of bias } \\
\hline Item & Authors' judgement & Description \\
\hline Allocation concealment? & Unclear & B - Unclear \\
\hline
\end{tabular}




\begin{tabular}{|c|c|}
\hline Methods & $\begin{array}{l}\text { Study design: RCT } \\
\text { Random allocation: Adequate (random number tables) } \\
\text { Allocation concealment: Unclear } \\
\text { Blinding of outcome assessors: Unclear } \\
\text { Length of intervention: } 12 \text { weeks } \\
\text { Unit of allocation: Participant } \\
\text { Unit of analysis: Participant } \\
\text { Protection against contamination: Unclear } \\
\text { Intention-to-treat analysis: Not done }\end{array}$ \\
\hline Participants & $\begin{array}{l}\text { Diagnosis of CHD or risk factors: Type } 2 \text { diabetes (newly diagnosed) } \\
\text { Exclusion criteria: Pregnant or lactating women, those aged }>70 \text { years, those with other endocrine or lipid } \\
\text { disorders, those who had received dietary advice in the past, those judged to need oral hypoglycaemic or } \\
\text { insulin therapy and patients where there was a language barrier. } \\
\text { Medications used: None reported } \\
\text { Smoking status: Not reported } \\
\mathrm{n}=60 \text { randomised, } 51 \text { completed. Control (standard diabetic dietary advice) group: baseline } \mathrm{n}=30 \text {, end } \\
\mathrm{n}=26 \text {. Intervention (Low GI) group: baseline } \mathrm{n}=30 \text {, end } \mathrm{n}=25 \\
\text { Mean age: Control (standard advice) } 56+/-3 \text { years, Low GI } 54+/-2 \text { years } \\
\text { Male/female ratio: Control (standard advice) } 76.9 \% / 23.1 \% \\
\text { Baseline characteristics: Reported } \\
\text { Geographical location: England }\end{array}$ \\
\hline
\end{tabular}

Interventions $\quad$ Intervention: Low GI diet . The low GI group received standard advice based on the British Diabetic Association dietary recommendations and further verbal and written information on low GI foods. The low glycaemic information was highlighted both verbally and in written form as the main aim of the diet. A dietary history was taken to give advice on meal patterns and how best to fit these recommendations into the subject's normal life.

Comparison interventions: Standard diabetic dietary advice. This group received advice based on the British Diabetic Association recommendations only.

Assessment of dietary compliance: Two 3-day food diaries, one at the end of week 4 and the other at the end of week 12. The results were expressed as the mean of the two food diaries.

Comparison of total energy and macronutrient intakes: Reported

Outcomes

Main outcomes: Fasting blood glucose, cholesterol, triglycerides, LDL-cholesterol, HDL cholesterol. Other outcomes: Fructosamine

Notes

Reported GI of diets: Low GI diet 73.9\% (mean), Standard diet 86.3\% (mean).

\section{Risk of bias}

\begin{tabular}{l|l|l}
\hline Item & Authors' judgement & Description \\
\hline Allocation concealment? & Unclear & B - Unclear \\
\hline
\end{tabular}




\begin{tabular}{ll} 
Methods & Study design: RCT \\
& Random allocation: Unclear \\
Allocation concealment: Unclear \\
Blinding of outcome assessors: Unclear \\
Length of intervention: 4 weeks \\
Unit of allocation: Participant \\
Unit of analysis: Participant \\
Protection against contamination: Unclear \\
Intention-to-treat analysis: Not done \\
\hline
\end{tabular}

\begin{tabular}{l} 
Darticipants \\
Exclusion criteria: Not reported \\
Medications used: Not reported \\
Smoking status: Not reported \\
$\mathrm{n}=32$ (?) randomised, 30 completed \\
Control (High GI group): baseline $\mathrm{n}=15$, end $\mathrm{n}=15$. Intervention (Low GI) group: baseline $\mathrm{n}=15$, \\
end $\mathrm{n}=15$ \\
Mean age: High GI $=63.5+/-2.0$ years, Low GI $=61.8+/-1.7$ years \\
Male/female ratio: High GI $=73.3 / 26.7 \%$, Low $\mathrm{GI}=80 / 20 \%$. \\
Baseline characteristics: Reported \\
Geographical location: England \\
\hline
\end{tabular}

Interventions Intervention: Low GI diet. Low GI subjects were encouraged to change one of their major carbohydrate sources to a low-glycaemic carbohydrate at each meal. All subjects completed a 7-day diary of habitual dietary intake. Dietary advice was based on the subjects normal energy and macronutrient intake. All subjects were given an individualised dietary plan and written advice. In both groups, subjects were given financial support over the period of the study to meet the costs of dietary change.

Comparison interventions: High GI diet. High GI subjects were encouraged to avoid Low Glycaemic Index foods and to eat rapidly absorbed carbohydrates and were given an individualised dietary plan. reported

Assessment of dietary compliance: Assessed at week 1 and week 4 but method not reported.

Comparison of total energy and macronutrient intakes: Reported

\begin{tabular}{|c|c|c|}
\hline Outcomes & \multicolumn{2}{|c|}{$\begin{array}{l}\text { Main outcomes: Fasting blood glucose, Fasting insulin, serum total cholesterol, serum triglycerides, serum } \\
\text { LDL-cholesterol, serum HDL cholesterol, body weight. } \\
\text { Other outcomes: insulin stimulated glucose uptake in isolated adipocytes, insulin incremental area under } \\
\text { the OGTT curve, glucose incremental area under the OGTT curve, free fatty acids }\end{array}$} \\
\hline Notes & \multicolumn{2}{|c|}{$\begin{array}{l}\text { Reported GI of diets: Low GI diet Week } 172+/-2 \% \text {, Week } 476+/-1 \% \text {, High GI diet Week } 190+/- \\
3 \% \text {, Week } 491+/-1 \% \text {. }\end{array}$} \\
\hline \multicolumn{3}{|l|}{ Risk of bias } \\
\hline Item & Authors' judgement & Description \\
\hline Allocation concealment? & Unclear & B - Unclear \\
\hline
\end{tabular}


Frost 2004

\begin{tabular}{|c|c|c|}
\hline Methods & \multicolumn{2}{|c|}{$\begin{array}{l}\text { Study design: Parallel RCT } \\
\text { Random allocation: Adequate (random numbers) } \\
\text { Allocation concealment: Unclear } \\
\text { Blinding of outcome assessors: Unclear } \\
\text { Length of intervention: } 12 \text { weeks } \\
\text { Unit of allocation: Participant } \\
\text { Unit of analysis: Participant } \\
\text { Protection against contamination: Unclear } \\
\text { Intention-to-treat analysis: Not done }\end{array}$} \\
\hline Participants & \multicolumn{2}{|c|}{$\begin{array}{l}\text { Diagnosis of CHD or risk factors: Participants had diagnosed myocardial infarction, unstable angina or } \\
\text { coronary artery disease. } \\
\text { Exclusion criteria: Cardiomyopathy, serious organ disease, systemic illness, chronic alcohol abuse, serious } \\
\text { psychiatric illness, poor compliance with food diaries or failed medical screening. } \\
\text { Medications used: Not reported } \\
\text { Smoking status: Not reported } \\
\mathrm{n}=57 \text { randomised, } 55 \text { completed } \\
\text { Mean age: LGI group } 63.6(\mathrm{SD}=9.4) \text {, Control (healthy eating) group } 61.8(\mathrm{SD}=9.0) \text {. } \\
\text { Male/female ratio: Low GI group 23/26. Control (healthy eating) } 25 / 29 \text {. } \\
\text { Baseline characteristics: Reported } \\
\text { Geographical location: UK }\end{array}$} \\
\hline Interventions & \multicolumn{2}{|c|}{$\begin{array}{l}\text { Intervention: Low GI diet - healthy eating advice emphasising low GI carbohydrates. Healthy eating } \\
\text { advice was similar to that in the control group except that the use of at least one low GI food (carbohydrate } \\
\text { with GI <85) at each meal was recommended. } \\
\text { Comparison interventions: Healthy eating diet. The diet was based on current health education guidelines } \\
\text { advocated by the COMA panel. The aim of the diet was to provide a diet with } 50 \% \text { carbohydrate and } \\
35 \% \text { of total energy as fat. Unrefined high cereal fibre carbohydrates were encouraged and a daily target } \\
\text { of five portions of fruit and vegetables was set. } \\
\text { Assessment of dietary compliance: } 7 \text { day diet diary recorded on } 4 \text { occasions during the study. } \\
\text { Comparison of total energy and macronutrient intakes: Reported }\end{array}$} \\
\hline Outcomes & \multicolumn{2}{|c|}{$\begin{array}{l}\text { Main outcomes: } \\
\text { Fasting glucose, fasting insulin, glycosylated hemoglobin, total cholesterol, LDL cholesterol, HDL choles- } \\
\text { terol, triglycerides, body weight } \\
\text { Other outcomes: systolic blood pressure, diastolic blood pressure. }\end{array}$} \\
\hline Notes & \multicolumn{2}{|c|}{$\begin{array}{l}\text { Reported GI of diets (at posttreatment): Low GI group } 71 \text { (SE 1), control group (healthy eating) } 81 \text { (SE } \\
\text { 1). The between group difference was significant ar } \mathrm{p}<0.05 \text {. }\end{array}$} \\
\hline \multicolumn{3}{|l|}{ Risk of bias } \\
\hline Item & Authors' judgement & Description \\
\hline Allocation concealment? & Unclear & B - Unclear \\
\hline
\end{tabular}


Giacco 2000

\begin{tabular}{|c|c|}
\hline Methods & $\begin{array}{l}\text { Study design: RCT } \\
\text { Random allocation: Unclear } \\
\text { Allocation concealment: Unclear } \\
\text { Blinding of outcome assessors: Unclear } \\
\text { Length of intervention: } 24 \text { weeks } \\
\text { Unit of allocation: Participant } \\
\text { Unit of analysis: Participant } \\
\text { Protection against contamination: Unclear } \\
\text { Intention-to-treat analysis: Reported but inadequate }\end{array}$ \\
\hline Participants & $\begin{array}{l}\text { Diagnosis of CHD or risk factors: Type } 1 \text { diabetes } \\
\text { Exclusion criteria: Those with renal failure, liver disease, symptomatic CVD, glycosylated haemoglobin } \\
<7 \text {, or }>10 \% \text {. } \\
\text { Medications used: Insulin ( } 2 \text { or more injections per day). The dose was only changed if plasma glucose } \\
\text { concentrations increased on repeated occasions or hypoglycaemic episodes increased regularly. } \\
\text { Smoking status: Not reported } \\
\mathrm{n}=63 \text { randomised, } 30 \text { completed } \\
\text { Control (Low fibre, high GI group): baseline } \mathrm{n}=31 \text {, end } \mathrm{n}=22 \text {. Intervention (High fibre, Low GI) } \\
\text { group: baseline } \mathrm{n}=32 \text {, end } \mathrm{n}=24 \\
\text { Mean age: } 28.2+/-9.5 \text { years } \\
\text { Male/female ratio: Low fibre, (High GI) }=36.0 / 64.0 \% \text {, High fibre (Low GI) }=41.4 / 58.6 \% \text {. } \\
\text { Baseline characteristics: Reported } \\
\text { Geographical location: Italy }\end{array}$ \\
\hline
\end{tabular}

Interventions $\quad$ Intervention: High fibre (Low GI) diet. Patients on the HF diet were advised to consume HF legumes, fruit and vegetables. All patients followed an intensive dietary education program that included diet history, a personalized diet, two 1-hour educational sessions with a dietitian. The test diet was prescribed to maintain energy and macronutrient intake. In addition individuals met with a dietitian once a month. Comparison interventions: Low fibre (High GI) diet. Low fibre, High GI subjects were encouraged to limit legume consumption to less than once a week and to consume preferentially LF fruit and vegetables. Other treatment was the same as for the HF, Low GI diet. Assessment of dietary compliance: monthly 7day food record Comparison of total energy and macronutrient intakes: Reported

Outcomes Main outcomes: Glycosylated haemoglobin, plasma triglycerides, plasma cholesterol, plasma HDL-cholesterol,body weight.

Other outcomes: mean daily plasma glucose, hypoglycaemic events, insulin dose.

Notes $\quad$ Reported (mean) GI of diets: High fibre (low GI) diet 70\%, Low fibre, high GI diet 90\%.

Risk of bias

\begin{tabular}{l|ll}
\hline Item & Authors' judgement & Description \\
\hline Allocation concealment? & Unclear & B - Unclear \\
\hline
\end{tabular}




\begin{tabular}{|c|c|}
\hline Methods & $\begin{array}{l}\text { Study design: RCT } \\
\text { Random allocation: Unclear } \\
\text { Allocation concealment: Unclear } \\
\text { Blinding of outcome assessors: Unclear } \\
\text { Length of intervention: } 8 \text { weeks } \\
\text { Unit of allocation: Participant } \\
\text { Unit of analysis: Participant } \\
\text { Protection against contamination: Unclear } \\
\text { Intention-to-treat analysis: Not done }\end{array}$ \\
\hline Participants & $\begin{array}{l}\text { Diagnosis of CHD or risk factors: Overweight subjects with Type } 2 \text { diabetes } \\
\text { Exclusion criteria: Those receiving treatment with oral hypoglycaemic agents, insulin or those with renal } \\
\text { or liver disease. } \\
\text { Medications used: Subjects taking lipid lowering medicine were requested to cease one month before the } \\
\text { trial. } \\
\text { Smoking status: Not reported } \\
\mathrm{n}=56 \text { randomised, } 45 \text { completed } \\
\text { Control (High GI group): baseline } \mathrm{n}=21 \text {, end } \mathrm{n}=21 \text {. Intervention (Low GI) group: baseline } \mathrm{n}=24 \text {, } \\
\text { end } \mathrm{n}=24 \\
\text { Mean age: High GI }=57.5+/-2.0 \text { years, Low GI }=56.0+/-2.0 \text { years } \\
\text { Male/female ratio: High GI }=57.1 / 42.9 \% \text {, Low GI }=45.8 / 54.2 \% \text {. } \\
\text { Baseline characteristics: Reported } \\
\text { Geographical location: Australia }\end{array}$ \\
\hline
\end{tabular}

Interventions

Intervention: Energy restricted Low GI diet. To maximise compliance, subjects were provided with 'key' foods, including breakfast cereals, breads, biscuits and low fat protein foods. Subjects attended dietary consultations every two weeks with the research dietitian to ensure compliance and were given detailed instructions on how to manipulate the diets in keeping with appropriate Glycaemic index and saturated fat contents.

Comparison interventions: Energy restricted High GI diet. Treatment as for Low GI above, replacing low GI foods with high GI.

Assessment of dietary compliance: Three day dietary intake records were completed every two weeks. Comparison of total energy and macronutrient intakes: Reported

Outcomes

Main outcomes: Body weight, Fasting plasma glucose, Glycosylated haemoglobin, total serum cholesterol, serum LDL cholesterol, serum HDL-cholesterol, serum triglycerides

Other outcomes:

Systolic BP, diastolic BP, Oral glucose tolerance test, area under glucose curve following oral GTT, urinary glucose excretion.

Notes $\quad$ Reported GI of diets: Low GI diet 43\%, High GI diet 75\%.

Risk of bias

\begin{tabular}{l|ll}
\hline Item & Authors' judgement & Description \\
\hline Allocation concealment? & Unclear & B - Unclear \\
\hline
\end{tabular}




Study design: Randomised crossover study
Random allocation: Unclear
Allocation concealment: Unclear
Blinding of outcome assessors: Unclear
Length of intervention: 6 weeks
Unit of allocation: Participant
Unit of analysis: Participant
Protection against contamination: Unclear
Intention-to-treat analysis: Not done

\begin{tabular}{ll}
\hline Participants & Diagnosis of CHD or risk factors: Type 2 diabetes \\
Exclusion criteria: Not reported \\
Medications used: Not reported \\
Smoking status: Not reported \\
$\mathrm{n}=36$ randomised, 14 completed \\
Mean age: 53 (SE 9) years. \\
Baseline characteristics: Reported \\
Geographical location: Mexico \\
\hline
\end{tabular}

\begin{tabular}{|c|c|c|}
\hline Interventions & \multicolumn{2}{|c|}{$\begin{array}{l}\text { Intervention: Low GI diet. Dietary instruction was provided on lower GI foods. Recommendations with } \\
\text { respect to the amount of carbohydrates were based on hte number of portions of grain, fruit, vegetables } \\
\text { and dairy products recommended in the Apple of Health illustration guide. Typical lower-GI foods were } \\
\text { oranges, beans, yogurt, pasta and corn tortillas. } \\
\text { Comparison interventions: High GI diet . The diet was as for the low GI diet described above but with } \\
\text { instructions on higher GI foods. Typical higher GI foods were corn flakes, white bread, potatoes and ripe } \\
\text { bananas. } \\
\text { Washout interval (for crossover studies) : } 6 \text { weeks } \\
\text { Assessment of dietary compliance: unweighed dietary intake diaries for } 1 \text { day during the first, fourth and } \\
\text { sixth week of the two study periods. Comparison of total energy and macronutrient intakes: Reported }\end{array}$} \\
\hline Outcomes & \multicolumn{2}{|c|}{$\begin{array}{l}\text { Main outcomes: fasting serum glucose, total cholesterol, LDL- cholesterol, HDL cholesterol, triglycerides, } \\
\text { glycosylated haemoglobin (A1c), body weight. } \\
\text { Other outcomes: BMI }\end{array}$} \\
\hline Notes & \multicolumn{2}{|c|}{$\begin{array}{l}\text { Reported GI of diets: Low GI diet } 44 \text { (SE 0.9), High GI diet } 56 \text { (SE 1.3). p=0.0001 (using Wilcoxon's } \\
\text { rank-sum test to compare). }\end{array}$} \\
\hline \multicolumn{3}{|l|}{ Risk of bias } \\
\hline Item & Authors' judgement & Description \\
\hline Allocation concealment? & Unclear & B - Unclear \\
\hline
\end{tabular}


Kabir 2002

\begin{tabular}{|c|c|}
\hline Methods & $\begin{array}{l}\text { Study design: Randomised cross-over study } \\
\text { Random allocation: Unclear } \\
\text { Allocation concealment: Unclear } \\
\text { Blinding of outcome assessors: Unclear (study described as double-blind but not clear who or what was } \\
\text { blinded) } \\
\text { Length of intervention: } 4 \text { weeks } \\
\text { Unit of allocation: Participant } \\
\text { Unit of analysis: Participant } \\
\text { Protection against contamination: Unclear } \\
\text { Intention-to-treat analysis: Not done }\end{array}$ \\
\hline Participants & $\begin{array}{l}\text { Diagnosis of CHD or risk factors: Type } 2 \text { diabetes } \\
\text { Exclusion criteria: Abnormal renal, hepatic, thyroid functions, blood cell count, gastrointestinal disorders } \\
\text { Medications used: } 12 / 13 \text { patients were on oral anti-diabetic agents (sulphonylurea and/or metformin) } \\
\text {. None of the patients were on insulin, } 4 \text { patients were being treated for hypertension with B-blockers, } \\
\text { ACE inhibitors, antidiuretics and/or calcium antagonists. Medication was kept constant throughout the } \\
\text { study. } \\
\text { Smoking status: Not reported } \\
\mathrm{n}=13 \text { randomised, } 13 \text { completed } \\
\text { Mean age: All subjects }=59+/-2 \text { years } \\
\text { Male/female ratio: } 100 \% \text { male } \\
\text { Baseline characteristics: Reported } \\
\text { Geographical location: France }\end{array}$ \\
\hline
\end{tabular}

Interventions

Intervention: Low GI breakfast composed of whole-grain bread and muesli containing B-glucan from oats. The size of the breakfast was fixed before the study and based on each patient's dietary record taken before the study to maintain the initial caloric intake and nutrient proportions constant throughout the study (recall technique). Patients received individual counseling by a dietitian concerning dietary food intake and small group counseling sessions. Treatment foods for breakfast were provided to the subjects and prescribed to meet $20 \%$ of daily energy requirements.

Comparison interventions: High GI breakfast composed of wholemeal bread and whole wheat breakfast cereal. Other treatment the same as for low GI.

Washout interval (for crossover studies) : 15 days

Assessment of dietary compliance: 7-day food diary on the last 7 days of each treatment period. Comparison of total energy and macronutrient intakes: Reported

Outcomes

Main outcomes: Glycosylated haemoglobin, fasting plasma glucose, fasting plasma insulin, plasma HDL cholesterol, total fasting plasma cholesterol, fasting plasma triglycerides, body weight .

Other outcomes: Effect on subject's lifestyles, AUC plasma glucose (3h), AUC insulin (3h), mean total cholesterol $(7 \mathrm{~h})$, mean triglycerides $(7 \mathrm{~h})$, fructosamine, free fatty acids, apolipoprotein $\mathrm{B}$, amount of mRNA of leptin in abdominal adipose tissue, peroxisome proliferator activated receptor-gamma, cholesterylester transfer protein mRNA amounts.

Risk of bias

Item

Authors' judgement

Description 
Kabir 2002 (Continued)

\begin{tabular}{lll}
\hline Allocation concealment? & Unclear & B - Unclear \\
\hline
\end{tabular}

Komindr 2001

\begin{tabular}{|c|c|}
\hline Methods & $\begin{array}{l}\text { Study design: Randomised cross-over study } \\
\text { Random allocation: Unclear } \\
\text { Allocation concealment: Unclear } \\
\text { Blinding of outcome assessors: Unclear } \\
\text { Length of intervention: } 4 \text { weeks } \\
\text { Unit of allocation: Participant } \\
\text { Unit of analysis: Participant } \\
\text { Protection against contamination: Unclear } \\
\text { Intention-to-treat analysis: Not done }\end{array}$ \\
\hline Participants & $\begin{array}{l}\text { Diagnosis of CHD or risk factors: Type } 2 \text { diabetes } \\
\text { Exclusion criteria: Diabetic complications, inability to consume test diets or to keep detailed food records, } \\
\text { fasting plasma glucose outwith } 140 \text { to } 280 \mathrm{mg} / \mathrm{dL} \text {. Medications used: Oral hypoglycaemic agents but } \\
\text { number of participants using medication not specified. } \\
\text { Smoking status: Not reported } \\
\mathrm{n}=10 \text { randomised, } 10 \text { completed } \\
\text { Mean age: not reported, age range } 32-60 \text { years } \\
\text { Male/female ratio: all female } \\
\text { Baseline characteristics: Reported } \\
\text { Geographical location: Thailand }\end{array}$ \\
\hline
\end{tabular}

Interventions Intervention: Low GI diet . Carbohydrate component of the diet consisted mainly of mungbean noodles and partly of rice noodles. Test carbohydrates were supplied to participants.

Comparison interventions: High GI diet. The carbohydrate content of the diet consisted mainly of glutinous rice and partly of rice-in-soup. Test carbohydrates were supplied to participants.

Washout interval (for crossover studies) : None reported

Assessment of dietary compliance: Not reported but pre-weighed test carbohydrates were supplied.

Comparison of total energy and macronutrient intakes: Reported

\begin{tabular}{ll} 
Outcomes & Main outcomes: \\
& Fasting plasma glucose, plasma insulin, HbA1c, body weight \\
& $\begin{array}{l}\text { Other outcomes: } \\
\text { BMI, waist to hip ratio,percentage of total body fat, serum albumin, hematocrit, diurnal plasma glucose, } \\
\text { integrated plasma glucose, diurnal serum insulin, integrated serum insulin, urinary glucose excretion }\end{array}$ \\
\hline Notes & $\begin{array}{l}\text { Reported GI of individual carbohydrate food, not whole diet. Low GI diet - mungbean noodles } 63, \text { rice } \\
\text { noodles } 76 ; \text { High GI diet - glutinous rice } 106 .\end{array}$
\end{tabular}

Risk of bias

\begin{tabular}{l|ll}
\hline Item & Authors' judgement & Description \\
\hline Allocation concealment? & Unclear & B - Unclear \\
\hline
\end{tabular}




\begin{tabular}{|c|c|}
\hline Methods & $\begin{array}{l}\text { Study design: Randomised cross-over study } \\
\text { Random allocation: Unclear } \\
\text { Allocation concealment: Unclear } \\
\text { Blinding of outcome assessors: Unclear } \\
\text { Length of intervention: } 4 \text { weeks } \\
\text { Unit of allocation: Participant } \\
\text { Unit of analysis: Participant } \\
\text { Protection against contamination: Unclear } \\
\text { Intention-to-treat analysis: Not done }\end{array}$ \\
\hline Participants & $\begin{array}{l}\text { Diagnosis of CHD or risk factors: Non-insulin dependent diabetes } \\
\text { Exclusion criteria: History of renal disease retinopathy or vascular problems } \\
\text { Medications used: } 16 / 21 \text { subjects were on oral anti-diabetic agents (sulphonylurea and/or metformin). } \\
\text { Drug dose was not altered during the study. None of the subjects were taking any drug known to affect } \\
\text { lipid metabolism. } \\
\text { Smoking status: Not reported } \\
\mathrm{n}=21 \text { randomised, } 21 \text { completed } \\
\text { Mean age: All subjects }=57.4+/-2.9 \text { years } \\
\text { Male/female ratio: } 66.7 / 33.3 \% \\
\text { Baseline characteristics: Reported } \\
\text { Geographical location: Australia }\end{array}$ \\
\hline Interventions & $\begin{array}{l}\text { Intervention: Low GI diet (high carbohydrate). Before the study, and at fortnightly intervals, subjects } \\
\text { received detailed dietary instructions on how to manipulate the GI. Specific study foods, dietary guidelines } \\
\text { and menus were provided to help subjects maintain compliance. The diets for all subjects were individu- } \\
\text { alised to maintain constant energy intake. Comparison interventions: High GI diet (high carbohydrate). } \\
\text { Treatment as for low GI diet. Washout interval (for crossover studies) : No washout between diets. } \\
\text { Assessment of dietary compliance: } 2 \text {-day weighed food records plus a } 24 \text { h diet recall which were combined } \\
\text { for analysis and completed fortnightly throughout each dietary phase. Comparison of total energy and } \\
\text { macronutrient intakes: Reported }\end{array}$ \\
\hline
\end{tabular}

Outcomes

Main outcomes: Body weight, fasting glucose, fasting insulin, total cholesterol, triacylglycerols, HDLcholesterol, LDL-cholesterol, glycated plasma protein.

Other outcomes:

fructosamine, $24 \mathrm{~h}$ urinary excretion of glucose and C-peptide

Notes Calculated GI of diets: Low GI 43\%, High GI 63\%.

Risk of bias

\begin{tabular}{l|ll}
\hline Item & Authors' judgement & Description \\
\hline Allocation concealment? & Unclear & B - Unclear \\
\hline
\end{tabular}




\begin{tabular}{ll} 
Study design: Parallel RCT \\
Random allocation: Adequate (random numbers) \\
Allocation concealment: Unclear (sealed envelopes were used but it is not reported if they were opaque). \\
Blinding of outcome assessors: Unclear \\
Length of intervention: 4 weeks \\
Unit of allocation: Participant \\
Unit of analysis: Participant \\
Protection against contamination: Unclear \\
Intention-to-treat analysis: Not done \\
\hline
\end{tabular}

Participants
were awaiting coronary artery bypass surgery.
Exclusion criteria: Not reported
Medications used: Not reported
Smoking status: Not reported
Number randomised is not reported, 35 completed
Mean age: Low GI group 59 (SE=7), High GI group $61(\mathrm{SE}=6)$.
Male/female ratio: Low GI group 16/2, High GI group 13/4.
Baseline characteristics: Reported
Geographical location: UK

Interventions Intervention: Low GI diet . 'Heart health diet' with the proportion of energy from carbohydrate $50 \%$ and the proportion of energy from fat $35 \%$ and advice was given on a daily target of five portions of fruit and veg. Additionally, there was emphasis on the use of low GI foods (carbohydrate with a GI <80. Participants were asked to swap a carbohydrate at each meal for a low GI carbohydrate such as pasta, basmati rice, wholegrain foods, granary breads, whole fruit, beans and pulse vegetables and milk.

Comparison interventions: High GI diet. The same 'heart health diet as decribed for the low GI group was used. Additionally, participants were asked to swap in high GI foods ( $>90)$ such as white bread, cornflakes, potatoes and told to avoid foods with GI $<80$ as listed above. Assessment of dietary compliance: 7-day unweighed food diaries that were validated against estimated energy expenditure at week 1 and week 4 . Each recorded intake was reviewed with the patients and portion sizes estimated using a portion size atlas. Comparison of total energy and macronutrient intakes: Reported

\begin{tabular}{|c|c|c|}
\hline Outcomes & \multicolumn{2}{|c|}{$\begin{array}{l}\text { Main outcomes: } \\
\text { Fasting glucose, fasting insulin, fasting cholesterol, fasting triglycerides, fasting LDL-cholesterol, fasting } \\
\text { HDL-cholesterol, } \\
\text { Other outcomes: }\end{array}$} \\
\hline Notes & \multicolumn{2}{|c|}{$\begin{array}{l}\text { Reported GI of diets: Low GI diet } 74 \text { (SE 1), High GI diet } 90 \text { (SE 2). Significant difference between the } \\
\text { groups } \mathrm{p}<0.05\end{array}$} \\
\hline \multicolumn{3}{|l|}{ Risk of bias } \\
\hline Item & Authors' judgement & Description \\
\hline Allocation concealment? & Unclear & B - Unclear \\
\hline
\end{tabular}




\begin{tabular}{|c|c|c|}
\hline Methods & \multicolumn{2}{|c|}{$\begin{array}{l}\text { Study design: Parallel RCT } \\
\text { Random allocation: Unclear } \\
\text { Allocation concealment: Unclear } \\
\text { Blinding of outcome assessors: Unclear } \\
\text { Length of intervention: } 24 \text { weeks } \\
\text { Unit of allocation: Participant } \\
\text { Unit of analysis: Participant } \\
\text { Protection against contamination: Unclear } \\
\text { Intention-to-treat analysis: Not done }\end{array}$} \\
\hline Participants & \multicolumn{2}{|c|}{$\begin{array}{l}\text { Diagnosis of CHD or risk factors: Obese participants, BMI } 30-40 \mathrm{kgm} 2 \text {. Exclusion criteria: Those taking } \\
\text { prescription medicines, with existing medical conditions or pregnancy. } \\
\text { Medications used: Individuals taking medication were excluded. } \\
\text { Smoking status: Not reported. } \\
42 \text { randomised to (to } 3 \text { groups), } 12 \text { week energy restricted diet prior to intervention, } 22 \text { completed, Low } \\
\text { GI group 6, High GI group 8, High fat group } 8 . \\
\text { Mean age: not reported } \\
\text { Male/female ratio: Low GI group 7/3, High GI group 7/3. } \\
\text { Baseline characteristics: Reported } \\
\text { Geographical location: US }\end{array}$} \\
\hline Interventions & \multicolumn{2}{|c|}{$\begin{array}{l}\text { Intervention: Low GI diet . Low glycaemic load and glycaemic index diet (energy reduced). The fatty } \\
\text { acid distribution of the diets was 1:1:1 for the ratio of polyunsaturated to monounsaturated to saturated } \\
\text { fatty acids. The cholesterol content of the diets was constant at } 100 \mathrm{~g} / 4184 \mathrm{~kJ} \text {. Modifications in GI were } \\
\text { achieved by utilizing carbohydrate foods with a lower GI for the LGI diet. The energy level was designed } \\
\text { to promote a weight loss of } 0.70 \mathrm{~kg} / \mathrm{wk} \text {. } \\
\text { Comparison interventions: High GI diet. As the low GI diet above except that low GI foods were not } \\
\text { used (it is not reported whether high GI foods were recommended). Assessment of dietary compliance: } \\
\text { 5-day food records at weeks } 12 \text { and } 24 \text { of the GI intervention phase. } \\
\text { Comparison of total energy and macronutrient intakes: Reported }\end{array}$} \\
\hline Outcomes & \multicolumn{2}{|c|}{$\begin{array}{l}\text { Main outcomes: Change in body weight, change in insulin sensitivity (HOMA), change in serum insulin, } \\
\text { change in plasma glucose, change in plasma triglycerides. } \\
\text { Other outcomes: } \\
\text { change in BMI, change in body fat, change in lean body mass }\end{array}$} \\
\hline Notes & \multicolumn{2}{|c|}{$\begin{array}{l}\text { Reported GI of diets: Initially subjects in the low GI group consumed a lower GI diet ( } \mathrm{p}=0.014 \text { after } 12 \\
\text { weeks of GI intervention), but at the end of the intervention ( } 24 \text { weeks), there was no difference in GI } \\
\text { between the } 2 \text { groups. No figures for GI of the diets were reported. }\end{array}$} \\
\hline \multicolumn{3}{|l|}{ Risk of bias } \\
\hline Item & Authors' judgement & Description \\
\hline Allocation concealment? & Unclear & B - Unclear \\
\hline
\end{tabular}




\begin{tabular}{|c|c|}
\hline Methods & $\begin{array}{l}\text { Study design: Parallel RCT } \\
\text { Random allocation: Unclear } \\
\text { Allocation concealment: Unclear } \\
\text { Blinding of outcome assessors: Unclear } \\
\text { Length of intervention: } 10 \text { weeks } \\
\text { Unit of allocation: Participant } \\
\text { Unit of analysis: Participant } \\
\text { Protection against contamination: Unclear } \\
\text { Intention-to-treat analysis: Not done }\end{array}$ \\
\hline Participants & $\begin{array}{l}\text { Diagnosis of CHD or risk factors: Overweight women (BMI } 25-30 \mathrm{kgm} 2) \text {. } \\
\text { Exclusion criteria: Outside age 20-40, BMI outside } 25-30 \text {, body weight fluctuations, physiologic or } \\
\text { psychological illness, use of medication (except birth control pills), blood pressure }>/=159 / 99 \mathrm{~mm} \mathrm{Hg} \text {, } \\
\text { allergies, special diets, high alcohol intake, smokers, elite athletes, those planning to change physical } \\
\text { activity levels, pregnancy, lactation, those who were post-menopausal, those who had donated blood in } \\
\text { the past } 3 \text { months. } \\
\text { Medications used: Participants on medication were excluded. Smoking status: Smokers were excluded } \\
\text { Number randomised 55, } 45 \text { completed } \\
\text { Mean age: Low GI group } 28.9 \text { (SE=1.3), High GI group } 30.8(\mathrm{SE}=1.3) \text {. } \\
\text { Male/female ratio: Low GI group all female, High GI group all female. } \\
\text { Baseline characteristics: Reported } \\
\text { Geographical location: Denmark }\end{array}$ \\
\hline
\end{tabular}

Interventions

Intervention: Low GI diet . Ad libitum, high carbohydrate (55-60\% of energy from carbohydrate), low fat $(<L=30 \%$ of energy from fat) diet, rich in LGI foods. Participants received carbohydrate-rich test foods from the research group every week. In the Low GI diet group, the test foods were wholegrain wheat bread, wholegrain rye bread, long-grain rice and pasta.

Comparison interventions: High GI diet. The diet was similar to the low GI diet described above, except that high GI test foods were supplied by the research group every week. In the high GI diet group, the test foods were wholemeal wheat bread, wholemeal rye bread, round grain rice and mashed potato powder. Macronutrient composition was kept similar in the 2 groups by adjusting protein and fat intake with a low-fat sour milk product and butter. Assessment of dietary compliance: 7-day weighed food diaries were completed before entering the study and in weeks 5 and 10 of the study period.

Comparison of total energy and macronutrient intakes: Reported

Main outcomes: Body weight,
Fasting glucose, fasting insulin, fasting cholesterol, fasting triglycerides, fasting LDL-cholesterol, fasting
HDL-cholesterol, Relative insulin resistance (HOMA-R).
Other outcomes:
General acceptability of the diets.

Notes

Reported GI of diets: Low GI diet 78.6 (SE not reported), High GI diet 102.8 (SE not reported). The figures above are for weighted glycaemic index determined from in vitro hydrolysis index.

\section{Risk of bias}

$\begin{array}{lll}\text { Item Authors' judgement } & \text { Description }\end{array}$

Allocation concealment? Unclear B - Unclear 
Taghrid 2004

\begin{tabular}{|c|c|c|}
\hline Methods & \multicolumn{2}{|c|}{$\begin{array}{l}\text { Study design: Randomised cross-over study } \\
\text { Random allocation: Unclear } \\
\text { Allocation concealment: Unclear } \\
\text { Blinding of outcome assessors: Unclear } \\
\text { Length of intervention: } 4 \text { weeks } \\
\text { Unit of allocation: Participant } \\
\text { Unit of analysis: Participant } \\
\text { Protection against contamination: Unclear } \\
\text { Intention-to-treat analysis: Not done }\end{array}$} \\
\hline Participants & \multicolumn{2}{|c|}{$\begin{array}{l}\text { Diagnosis of CHD or risk factors: Type } 2 \text { diabetes } \\
\text { Exclusion criteria: No information } \\
\text { Medications used: No information } \\
\text { Smoking status: No information } \\
\mathrm{n}=12 \text { randomised, } 12 \text { completed } \\
\text { Mean age: No information } \\
\text { Male/female ratio: } 100 \% \text { male } \\
\text { Baseline characteristics: Reported } \\
\text { Geographical location: France }\end{array}$} \\
\hline Interventions & \multicolumn{2}{|c|}{$\begin{array}{l}\text { Intervention: Low GI diet . } \\
\text { Comparison interventions: High GI diet. } \\
\text { Washout interval: } \\
\text { Two weeks. } \\
\text { Assessment of dietary compliance: No information } \\
\text { Comparison of total energy and macronutrient intakes: Reported }\end{array}$} \\
\hline Outcomes & \multicolumn{2}{|c|}{$\begin{array}{l}\text { Main outcomes: Body weight, fasting glucose, fasting insulin glycosylated haemoglobin, fasting cholesterol, } \\
\text { HDL cholesterol, LDL cholesterol, triacylglycerols. } \\
\text { Other outcomes: } \\
\text { Not yet published }\end{array}$} \\
\hline Notes & \multicolumn{2}{|c|}{ Calculated GI of diets: Low GI 39\%, High GI $71 \%$. } \\
\hline \multicolumn{3}{|l|}{ Risk of bias } \\
\hline Item & Authors' judgement & Description \\
\hline Allocation concealment? & Unclear & B - Unclear \\
\hline
\end{tabular}


Tsihlias 2000

\begin{tabular}{|c|c|}
\hline Methods & $\begin{array}{l}\text { Study design: RCT } \\
\text { Random allocation: Unclear } \\
\text { Allocation concealment: Unclear } \\
\text { Blinding of outcome assessors: Unclear } \\
\text { Length of intervention: } 6 \text { months } \\
\text { Unit of allocation: Participant } \\
\text { Unit of analysis: Participant } \\
\text { Protection against contamination: Unclear } \\
\text { Intention-to-treat analysis: Not done }\end{array}$ \\
\hline Participants & $\begin{array}{l}\text { Diagnosis of CHD or risk factors: Subjects with Type } 2 \text { diabetes for }>6 \text { months. } \\
\text { Exclusion criteria: pregnancy, aged }<40 \text { or }>80 \text { years, biochemical evidence of impaired renal or hepatic } \\
\text { function, BMI }>36 \text {, glycosylated haemoglobin }<6.5 \% \text {, serum triacylglycerol }>10 \mathrm{mmol} / \mathrm{L} \text {. } \\
\text { Medications used: Subjects who were being treated with insulin or acarbose were excluded. Subjects on } \\
\text { a stable dose of metformin or sulphonylurea or both were included. Subjects with changes in the type } \\
\text { or dose of oral hypoglycaemic agent in the first } 3 \text { months were dropped from the study If the change } \\
\text { occurred after } 3 \text { months, the subjects were dropped from the study but the baseline and } 3 \text { month results } \\
\text { were included in the analysis (except for blood lipids results). } \\
\text { Smoking status: Not reported } \\
\mathrm{n}=59 \text { randomised, } 46 \text { completed } \\
\text { Control (High GI group): baseline } \mathrm{n}=29 \text {, end } \mathrm{n}=21 \text {. Intervention (Low GI) group: baseline } \mathrm{n}=30 \text {, } \\
\text { end } \mathrm{n}=25 \\
\text { Mean age: High GI }=28.0+/-0.7 \text { years, Low GI }=27.7+/-0.7 \text { years } \\
\text { Male/female ratio: No significant difference between the study groups. } \\
\text { Baseline characteristics: Reported } \\
\text { Geographical location: Canada }\end{array}$ \\
\hline
\end{tabular}

Interventions Intervention: Low GI breakfast cereal. Treatment foods were provided to the subjects and prescribed to meet $10-15 \%$ of energy requirements. Daily energy requirements were calculated from data from the Lipid Research Clinics Prevalence Study with $1254 \mathrm{~kJ}$ (300kcal) added for weight maintenance or 836kJ subtracted for weight loss (BMI >27).

Comparison interventions: High GI breakfast cereal. Treatment as for low GI diet. Assessment of dietary compliance: Compliance was assessed as the difference between the amount of treatment food provided at the previous clinic visit and the amount returned at the present visit.

Comparison of total energy and macronutrient intakes: Reported

\begin{tabular}{ll} 
Outcomes & $\begin{array}{l}\text { Main outcomes: } \\
\text { Body weight, fasting glucose, glycosylated haemoglobin, total cholesterol, LDL cholesterol, HDL choles- } \\
\text { terol, triacylglycerols. } \\
\text { Other outcomes: } 8 \text {-h metabolic profiles of plasma glucose, insulin, fatty acid, triacylglycerol and mean 8- } \\
\text { h plasma glucose, insulin, fatty acid and triacylglycerol concentrations. }\end{array}$ \\
\hline Notes & Calculated (mean) GI of diets: Low GI $75.8 \%$, High GI $86.1 \%$
\end{tabular}

Risk of bias

\begin{tabular}{l|ll}
\hline Item & Authors' judgement & Description \\
\hline Allocation concealment? & Unclear & B - Unclear \\
\hline
\end{tabular}


Wolever 1992a

\begin{tabular}{|c|c|c|}
\hline Methods & \multicolumn{2}{|c|}{$\begin{array}{l}\text { Study design: Randomised cross-over study } \\
\text { Random allocation: Unclear } \\
\text { Allocation concealment: Unclear } \\
\text { Blinding of outcome assessors: Unclear } \\
\text { Length of intervention: } 6 \text { weeks } \\
\text { Unit of allocation: Participant } \\
\text { Unit of analysis: Participant } \\
\text { Protection against contamination: Unclear } \\
\text { Intention-to-treat analysis: Not done }\end{array}$} \\
\hline Participants & \multicolumn{2}{|c|}{$\begin{array}{l}\text { Diagnosis of CHD or risk factors: Non-insulin dependent diabetes and obese/overweight. } \\
\text { Exclusion criteria: Not reported } \\
\text { Medications used: Not reported } \\
\text { Smoking status: Not reported } \\
\mathrm{n}=6 \text { randomised, } 6 \text { completed } \\
\text { Mean age: } 63+/-4 \text { years. } \\
\text { Male/female ratio: } 50 \% / 50 \% \\
\text { Baseline characteristics: Reported } \\
\text { Geographical location: Canada }\end{array}$} \\
\hline Interventions & \multicolumn{2}{|c|}{$\begin{array}{l}\text { Intervention: Low GI diet (reduced energy). Diets were designed to be moderately reduced in energy to } \\
\text { induce } 0.5 \text { to } 1 \mathrm{~kg} \text { weight loss/week. For the first and last two weeks of each dietary period, subjects wer } \\
\text { provided with pre-weighed portions of all starchy foods, cheese and tinned sauces in their diets. Subject } \\
\text { provided with a detailed daily menu plan. } \\
\text { Comparison interventions: High GI diet. Treatment as for low GI diet. Washout interval (for crossove } \\
\text { studies) : } 4 \text { to } 6 \text { weeks } \\
\text { Assessment of dietary compliance: Not reported } \\
\text { Comparison of total energy and macronutrient intakes: Reported }\end{array}$} \\
\hline Outcomes & \multicolumn{2}{|c|}{$\begin{array}{l}\text { Main outcomes: Body weight, fasting glucose, total cholesterol, triglycerides, HDL-cholesterol, LDI } \\
\text { cholesterol. } \\
\text { Other outcomes: fructosamine }\end{array}$} \\
\hline Notes & \multicolumn{2}{|c|}{ Calculated (mean) GI of diets: Low GI $58 \%$, High GI $86 \%$. } \\
\hline \multicolumn{3}{|l|}{ Risk of bias } \\
\hline Item & Authors' judgement & Description \\
\hline Allocation concealment? & Unclear & B - Unclear \\
\hline
\end{tabular}


Wolever 2002

\begin{tabular}{|c|c|}
\hline Methods & $\begin{array}{l}\text { Study design: RCT } \\
\text { Random allocation: Adequate (coin toss) } \\
\text { Allocation concealment: Unclear } \\
\text { Blinding of outcome assessors: Unclear } \\
\text { Length of intervention: } 16 \text { weeks } \\
\text { Unit of allocation: Participant } \\
\text { Unit of analysis: Participant } \\
\text { Protection against contamination: Unclear } \\
\text { Intention-to-treat analysis: Not done }\end{array}$ \\
\hline Participants & $\begin{array}{l}\text { Diagnosis of CHD or risk factors: Subjects with impaired glucose tolerance and at least one risk factor for } \\
\text { diabetes. } \\
\text { Exclusion criteria: pregnancy, aged }<30 \text { or }>65 \text { years, BMI }>40 \text {, serum triacylglycerol }>10 \mathrm{mmol} / \mathrm{L} \text {. } \\
\text { Medications used: Thiazide diuretics were used by one high GI subject. B-blockers were taken by one low } \\
\text { GI subject. } \\
\text { Smoking status: Not reported } \\
\mathrm{n}=24 \text { randomised, } 22 \text { completed } \\
\text { Control (High GI group): baseline } \mathrm{n}=11 \text {, end } \mathrm{n}=9 \text {. Intervention (Low GI) group: baseline } \mathrm{n}=13 \text {, end } \\
\mathrm{n}=13 \\
\text { Mean age: } 55.6+/-2.1 \\
\text { Male/female ratio: } 20.6 \%: 79.4 \% \text { (in } 3 \text { arms of study) } \\
\text { Baseline characteristics: Reported } \\
\text { Geographical location: Canada }\end{array}$ \\
\hline
\end{tabular}

Interventions Intervention: Low GI diet (high carbohydrate). Diets were prescribed on an ad libitum basis based on two 3-day food records during the baseline period. The aim was for the diets to be weight maintaining. Specific food products to be used in the diet were provided to subjects. Subjects were seen monthly for consultations with a dietitian. Comparison interventions: High GI diet (high carbohydrate). Treatment as for low GI diet.

Assessment of dietary compliance: 3-day food records completed monthly. Comparison of total energy and macronutrient intakes: Reported

Outcomes

Main outcomes: Body weight, fasting LDL cholesterol, diastolic blood pressure, fasting plasma glucose, glycosylated haemoglobin, fasting total cholesterol, fasting triglycerides, HDL cholesterol

Other outcomes:

Insulin sensitivity, glucose effectiveness, pancreatic resposivity, glucose disposition index, postprandial plasma glucose, insulin, triacylglycerol, free fatty acids

Notes

Calculated (mean) GI of diets: Low GI 54.4\% +/- 0.7 (SE), High GI diet 59.3 +/- 0.6 (SE).

Risk of bias

\begin{tabular}{l|ll}
\hline Item & Authors' judgement & Description \\
\hline Allocation concealment? & Unclear & B - Unclear \\
\hline
\end{tabular}

Taghrid 2003 study. Information based on two short abstracts and unpublished data provided by the authors. A further full paper is due for submission late 2003.

Low glycaemic index diets for coronary heart disease (Review) 
Calle-Pascual 1988 - The study design is not clear from the published details but the authors (A.L. Calle-Pascual) have confirmed to us that the study was of open, randomised cross-over design.

AUC $=$ Area under curve data

\section{Characteristics of excluded studies [ordered by study ID]}

\begin{tabular}{|c|c|}
\hline Abbasi 2000 & $\begin{array}{l}\text { Participants not diagnosed with CHD or at risk of CHD } \\
\text { GI of the diet not reported or compared } \\
\text { Intervention }<4 \text { weeks }\end{array}$ \\
\hline Agus 2000 & Intervention $<4$ weeks \\
\hline Alfenas 2005 & $\begin{array}{l}\text { Intervention }<4 \text { weeks } \\
\text { Participants not diagnosed with CHD or at risk of CHD } \\
\text { Participants not free-living }\end{array}$ \\
\hline Bahadori 2005 & Not an RCT \\
\hline Barkoukis 2002 & $\begin{array}{l}\text { Participants not diagnosed with CHD or at risk of CHD } \\
\text { Intervention }<4 \text { weeks }\end{array}$ \\
\hline Brynes 2003 & Intervention $<4$ weeks \\
\hline Chanteleau 1985 & Intervention $<4$ weeks \\
\hline Clapp 1998 & $\begin{array}{l}\text { Participants not diagnosed with CHD or at risk of CHD } \\
\text { Participants pregnant }\end{array}$ \\
\hline Colagiuri 1986 & $\begin{array}{l}\text { Intervention }<4 \text { weeks } \\
\text { GI of diets not reported or compared }\end{array}$ \\
\hline Collier 1986 & $\begin{array}{l}\text { Comparison not between diets with similar overall energy and macronutrient contents } \\
\text { Intervention }<4 \text { weeks } \\
\text { CHD mortality, morbidity or risk factor outcomes not reported }\end{array}$ \\
\hline Collier 1988 & Intervention in children \\
\hline Coulston 1984 & Intervention $<4$ weeks \\
\hline Crapo 1981 & $\begin{array}{l}\text { GI of diets not reported or compared } \\
\text { Participants not free-living } \\
\text { Intervention }<4 \text { weeks }\end{array}$ \\
\hline Dumesnil 2001 & $\begin{array}{l}\text { Comparison not between diets with similar energy and macronutrient contents } \\
\text { Participants not free-living } \\
\text { Intervention }<4 \text { weeks }\end{array}$ \\
\hline Ebbeling 2003 & Comparison not between diets with similar energy and macronutrient contents \\
\hline
\end{tabular}


(Continued)

\begin{tabular}{|c|c|}
\hline Ebbeling 2005 & Comparison not between diets with similar energy and macronutrient contents \\
\hline Fontvielle 1988 & Intervention $<4$ weeks \\
\hline Frost $1998 \mathrm{a}$ & Intervention $<4$ weeks \\
\hline Frost $1998 \mathrm{~b}$ & Not a dietary intervention \\
\hline Frost $1999 \mathrm{~b}$ & Not an RCT or CCT \\
\hline Fuh 1990 & $\begin{array}{l}\text { Participants not free-living } \\
\text { GI of diets not reported or compared } \\
\text { Comparison not between diets with similar overall energy and macronutrient levels } \\
\text { Intervention }<4 \text { weeks }\end{array}$ \\
\hline Garg 1988 & $\begin{array}{l}\text { GI of diets not reported or compared } \\
\text { Participants not free-living }\end{array}$ \\
\hline Garg 1992 & $\begin{array}{l}\text { GI of diets not reported or compared } \\
\text { Comparison not between diets with similar overall energy and macronutrient intakes } \\
\text { Participants not free-living } \\
\text { Intervention }<4 \text { weeks }\end{array}$ \\
\hline Garg 1994 & GI of diets not reported or compared \\
\hline Gilbertson 2001 & Participants are children \\
\hline Gilbertson 2003 & Study does not report CHD risk factors or outcomes \\
\hline Golay 1992 & Intervention $<4$ weeks \\
\hline Herrmann 2001 & $\begin{array}{l}\text { Participants not diagnosed with CHD or at risk of CHD } \\
\text { Intervention }<4 \text { weeks }\end{array}$ \\
\hline Hollenbeck 1985 & $\begin{array}{l}\text { GI of diets not reported or compared } \\
\text { Comparisons not between diets with similar overall energy and macronutrient levels }\end{array}$ \\
\hline Jarvi 1995 & Intervention $<4$ weeks \\
\hline Jarvi 1999 & Intervention $<4$ weeks \\
\hline Jenkins 1985 & Not RCT or CCT \\
\hline Jenkins $1987 \mathrm{a}$ & $\begin{array}{l}\text { Participants not diagnosed with CHD or at risk of CHD } \\
\text { Intervention }<4 \text { weeks }\end{array}$ \\
\hline Jenkins $1987 \mathrm{~b}$ & Not RCT or CCT \\
\hline
\end{tabular}


(Continued)

\begin{tabular}{|c|c|}
\hline Jenkins 1988 & Intervention $<4$ weeks \\
\hline Jenkins 2002a & $\begin{array}{l}\text { GI of diets not reported or compared } \\
\text { Participants not free-living }\end{array}$ \\
\hline Jenkins $2002 b$ & Intervention $<4$ weeks \\
\hline Jeppesen 1997 & $\begin{array}{l}\text { Participants not diagnosed with CHD or at risk of CHD } \\
\text { GI of diets not reported or compared } \\
\text { Comparisons not between diets with similar overall energy and macronutrient contents } \\
\text { Intervention }<4 \text { weeks }\end{array}$ \\
\hline Jiminez-Cruz 2003b & Intervention $<4$ weeks \\
\hline Jiminez-Cruz 2004 & Intervention $<4$ weeks \\
\hline Kiens 1996 & Participants not diagnosed with $\mathrm{CHD}$ or at risk of $\mathrm{CHD}$ \\
\hline Lafrance 1998 & Intervention $<4$ weeks \\
\hline LaHaye 2005 & Not an RCT \\
\hline Laitinen 1993 & GI of diets not reported or compared \\
\hline Leinonen 2000 & GI of diet not reported or compared \\
\hline Lerman-Garber 1995 & $\begin{array}{l}\text { GI of diets not reported or compared } \\
\text { Comparison not between diets with similar overall energy and macronutrient contents }\end{array}$ \\
\hline Lieberman 2003 & Not an RCT \\
\hline Liu 2000 & Not RCT or CCT \\
\hline Liu $2002 a$ & Not RCT or CCT \\
\hline Ludwig 1999 & Participants are children \\
\hline Lunetta 1996 & $\begin{array}{l}\text { Intervention }<4 \text { weeks } \\
\text { Participants not free-living }\end{array}$ \\
\hline Morales 1997 & $\begin{array}{l}\text { Not RCT or CCT } \\
\text { Child }\end{array}$ \\
\hline Pacy 1984 & $\begin{array}{l}\text { GI of diets not reported or compared } \\
\text { Comparison not between diets with similar overall energy and macronutrient contents }\end{array}$ \\
\hline
\end{tabular}


(Continued)

\begin{tabular}{|c|c|}
\hline Percheron 1997 & $\begin{array}{l}\text { Comparison not between diets with similar energy and macronutrient levels } \\
\text { Participants not free-living } \\
\text { Intervention }<4 \text { weeks }\end{array}$ \\
\hline Pereira 2002 & GI of diets not reported or compared \\
\hline Pereira 2004 & Comparison not between diets with similar energy and macronutrient levels \\
\hline Pittas 2005 & Comparison not between diets with similar energy and macronutrient levels \\
\hline Poppitt 2002 & GI of the diets not reported or compared \\
\hline Rabasa-Lhoret 1999 & $\begin{array}{l}\text { Comparison not between diets with similar overall energy and macronutrient levels. } \\
\text { Participants not free-living } \\
\text { Intervention }<4 \text { weeks }\end{array}$ \\
\hline Rasmussen 1993 & $\begin{array}{l}\text { GI of diets not reported or compared } \\
\text { Comparison not between diets with similar overall energy and macronutrient contents }\end{array}$ \\
\hline Salmeron 1997 & Not an RCT or CCT \\
\hline Santacroce 1990 & GI of diets not reported or compared \\
\hline Scholz 2003 & Intervention $<4$ weeks \\
\hline Sciarrone 1993 & Participants not diagnosed with $\mathrm{CHD}$ or at risk of $\mathrm{CHD}$ \\
\hline Sharafetdinov 1997 & Intervention $<4$ weeks \\
\hline Singh 1991 & $\begin{array}{l}\text { GI of the diets not reported or compared } \\
\text { Comparison not between diets of similar energy and macronutrient intake }\end{array}$ \\
\hline Slabber 1994 & GI of the diets not reported or compared \\
\hline Spieth 2000 & Participants are children \\
\hline Van Horn 1991 & GI of diets not reported or compared \\
\hline Wolever $1992 \mathrm{~b}$ & Intervention $<4$ weeks \\
\hline Wolever 1995 & $\begin{array}{l}\text { Participants not diagnosed with CHD or at risk of CHD } \\
\text { Intervention less than } 4 \text { weeks }\end{array}$ \\
\hline Yang 2002 & Not an RCT \\
\hline
\end{tabular}




\section{DATA AND ANALYSES}

Comparison 1. Total cholesterol (parallel and cross-over studies)

\begin{tabular}{lcccc} 
Outcome or subgroup title & $\begin{array}{c}\text { No. of } \\
\text { studies }\end{array}$ & $\begin{array}{c}\text { No. of } \\
\text { participants }\end{array}$ & Statistical method & Effect size \\
\hline $\begin{array}{l}1 \text { All endpoint outcomes }(\mathrm{mmol} / \\
\text { L) }\end{array}$ & 17 & 607 & Mean Difference (IV, Fixed, 95\% CI) & $-0.16[-0.29,-0.02]$ \\
\hline
\end{tabular}

Comparison 2. Total cholesterol (whole-diet studies only, parallel and crossover studies)

\begin{tabular}{lcccc} 
Outcome or subgroup title & $\begin{array}{c}\text { No. of } \\
\text { studies }\end{array}$ & $\begin{array}{c}\text { No. of } \\
\text { participants }\end{array}$ & Statistical method & Effect size \\
\hline $\begin{array}{l}14 \text { and } 5 \text { week outcomes (mmol/ } \\
\text { L) }\end{array}$ & 8 & 225 & Mean Difference (IV, Fixed, 95\% CI) & $-0.04[-0.28,0.20]$ \\
212 week outcomes (mmol/L) & 4 & 162 & Mean Difference (IV, Fixed, 95\% CI) & $0.01[-0.26,0.29]$ \\
$\begin{array}{l}\text { All endpoint outcomes (mmol/ } \\
\text { L) }\end{array}$ & 15 & 535 & Mean Difference (IV, Fixed, 95\% CI) & $-0.17[-0.32,-0.02]$ \\
\hline
\end{tabular}

Comparison 3. HDL cholesterol (parallel and cross-over studies)

\begin{tabular}{lcccc} 
Outcome or subgroup title & $\begin{array}{c}\text { No. of } \\
\text { studies }\end{array}$ & $\begin{array}{c}\text { No. of } \\
\text { participants }\end{array}$ & Statistical method & Effect size \\
\hline $\begin{array}{l}1 \text { All endpoint outcomes }(\mathrm{mmol} / \\
\text { L) }\end{array}$ & 16 & & Mean Difference (IV, Fixed, 95\% CI) & Subtotals only \\
\hline
\end{tabular}


Comparison 4. HDL cholesterol (parallel studies only)

\begin{tabular}{lcccc} 
Outcome or subgroup title & $\begin{array}{c}\text { No. of } \\
\text { studies }\end{array}$ & $\begin{array}{c}\text { No. of } \\
\text { participants }\end{array}$ & Statistical method & Effect size \\
\hline $\begin{array}{l}14 \text { and } 5 \text { week outcomes }(\mathrm{mmol} / \\
\text { L) }\end{array}$ & 3 & 89 & Mean Difference (IV, Fixed, 95\% CI) & $-0.11[-0.20,-0.01]$ \\
212 week outcomes & 4 & & Mean Difference (IV, Fixed, 95\% CI) & Subtotals only \\
\hline
\end{tabular}

Comparison 5. LDL cholesterol (parallel and cross-over studies)

\begin{tabular}{lcccc} 
Outcome or subgroup title & $\begin{array}{c}\text { No. of } \\
\text { studies }\end{array}$ & $\begin{array}{c}\text { No. of } \\
\text { participants }\end{array}$ & Statistical method & Effect size \\
\hline $\begin{array}{l}1 \text { All endpoint outcomes (mmol/ } \\
\text { L) }\end{array}$ & 14 & 482 & Mean Difference (IV, Fixed, 95\% CI) & $-0.15[-0.30,0.01]$ \\
$\begin{array}{l}2 \text { All endpoint outcomes (without } \\
\text { Wolever 2002 study) }\end{array}$ & 13 & 458 & Mean Difference (IV, Fixed, 95\% CI) & $-0.16[-0.32,-0.00]$ \\
\hline
\end{tabular}

Comparison 6. Triglycerides (parallel and cross-over studies)

\begin{tabular}{lcccc} 
Outcome or subgroup title & $\begin{array}{c}\text { No. of } \\
\text { studies }\end{array}$ & $\begin{array}{c}\text { No. of } \\
\text { participants }\end{array}$ & Statistical method & Effect size \\
\hline 1 All endpoint data $(\mathrm{mmol} / \mathrm{L})$ & 18 & 625 & Mean Difference (IV, Fixed, 95\% CI) & $0.01[-0.09,0.11]$ \\
\hline
\end{tabular}

Comparison 7. Body weight (parallel and cross-over studies)

\begin{tabular}{lcccc} 
Outcome or subgroup title & $\begin{array}{c}\text { No. of } \\
\text { studies }\end{array}$ & $\begin{array}{c}\text { No. of } \\
\text { participants }\end{array}$ & Statistical method & Effect size \\
\hline 1 All endpoint outcomes $(\mathrm{kg})$ & 17 & 583 & Mean Difference (IV, Fixed, 95\% CI) & $0.04[-0.73,0.82]$ \\
\hline
\end{tabular}


Comparison 8. Fasting glucose (parallel and cross-over studies)

\begin{tabular}{lcccc} 
Outcome or subgroup title & $\begin{array}{c}\text { No. of } \\
\text { studies }\end{array}$ & $\begin{array}{c}\text { No. of } \\
\text { participants }\end{array}$ & Statistical method & Effect size \\
\hline $\begin{array}{l}\text { 1 All endpoint outcomes (mmol/ } \\
\text { L) }\end{array}$ & 17 & 570 & Mean Difference (IV, Fixed, 95\% CI) & $0.14[0.02,0.26]$ \\
\hline
\end{tabular}

Comparison 9. Fasting insulin (parallel and cross-over studies)

\begin{tabular}{lcccc} 
Outcome or subgroup title & $\begin{array}{c}\text { No. of } \\
\text { studies }\end{array}$ & $\begin{array}{c}\text { No. of } \\
\text { participants }\end{array}$ & Statistical method & Effect size \\
\hline 1 All endpoint outcomes & 9 & 298 & Mean Difference (IV, Fixed, 95\% CI) & $-1.55[-8.52,5.43]$ \\
\hline
\end{tabular}

Comparison 10. HbAlc (parallel and cross-over studies)

\begin{tabular}{lcclc} 
Outcome or subgroup title & $\begin{array}{c}\text { No. of } \\
\text { studies }\end{array}$ & $\begin{array}{c}\text { No. of } \\
\text { participants }\end{array}$ & Statistical method & Effect size \\
\hline 1 All endpoint outcomes (\%) & 12 & 438 & Mean Difference (IV, Fixed, 95\% CI) & $-0.09[-0.22,0.04]$ \\
212 week outcomes (\%) & 4 & 157 & Mean Difference (IV, Fixed, 95\% CI) & $-0.11[-0.28,0.06]$ \\
312 week outcomes (\%) without & 3 & 102 & Mean Difference (IV, Fixed, 95\% CI) & $-0.45[-0.82,-0.09]$ \\
$\quad$ Frost 1996 & & & & \\
\hline
\end{tabular}


Analysis I.I. Comparison I Total cholesterol (parallel and cross-over studies), Outcome I All endpoint outcomes (mmol/L).

Review: Low glycaemic index diets for coronary heart disease

Comparison: I Total cholesterol (parallel and cross-over studies)

Outcome: I All endpoint outcomes (mmol/L)

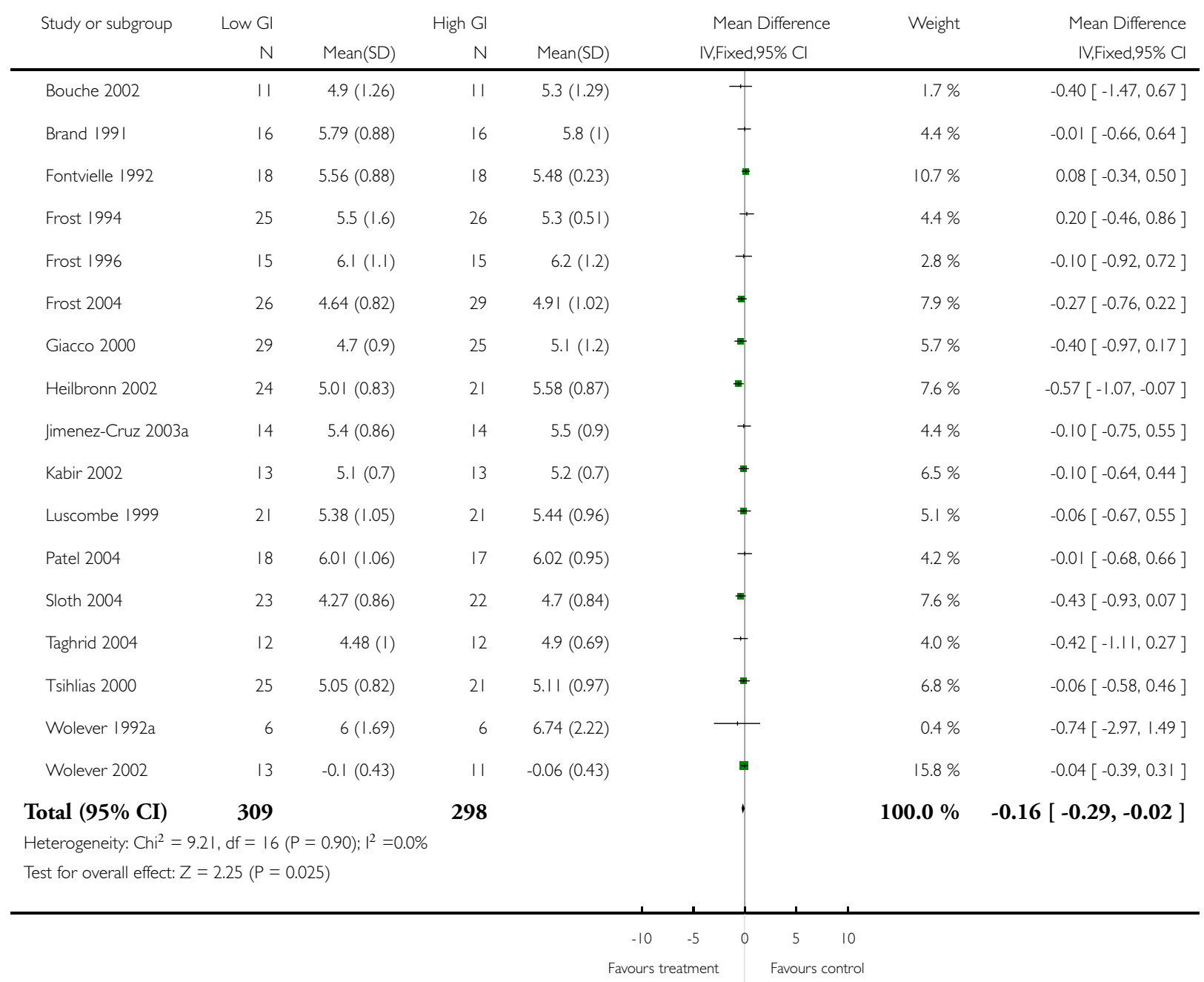


Analysis 2.I. Comparison 2 Total cholesterol (whole-diet studies only, parallel and crossover studies), Outcome I 4 and 5 week outcomes ( $\mathrm{mmol} / \mathrm{L})$.

Review: Low glycaemic index diets for coronary heart disease

Comparison: 2 Total cholesterol (whole-diet studies only, parallel and crossover studies)

Outcome: $\quad 4$ and 5 week outcomes $(\mathrm{mmol} / \mathrm{L})$

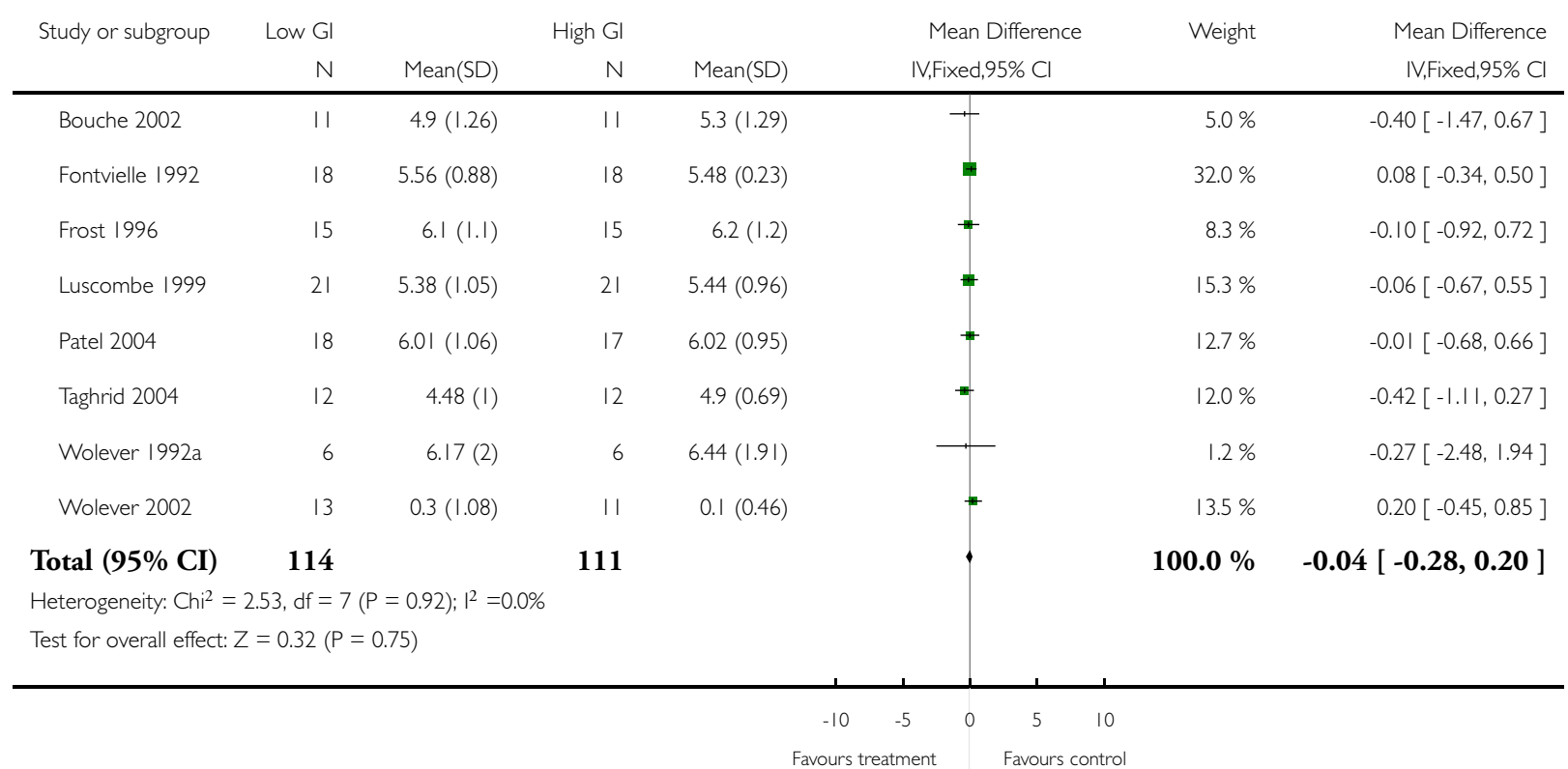


Analysis 2.2. Comparison 2 Total cholesterol (whole-diet studies only, parallel and crossover studies), Outcome 2 I 2 week outcomes ( $\mathrm{mmol} / \mathrm{L})$.

Review: Low glycaemic index diets for coronary heart disease

Comparison: 2 Total cholesterol (whole-diet studies only, parallel and crossover studies)

Outcome: 212 week outcomes $(\mathrm{mmol} / \mathrm{L})$

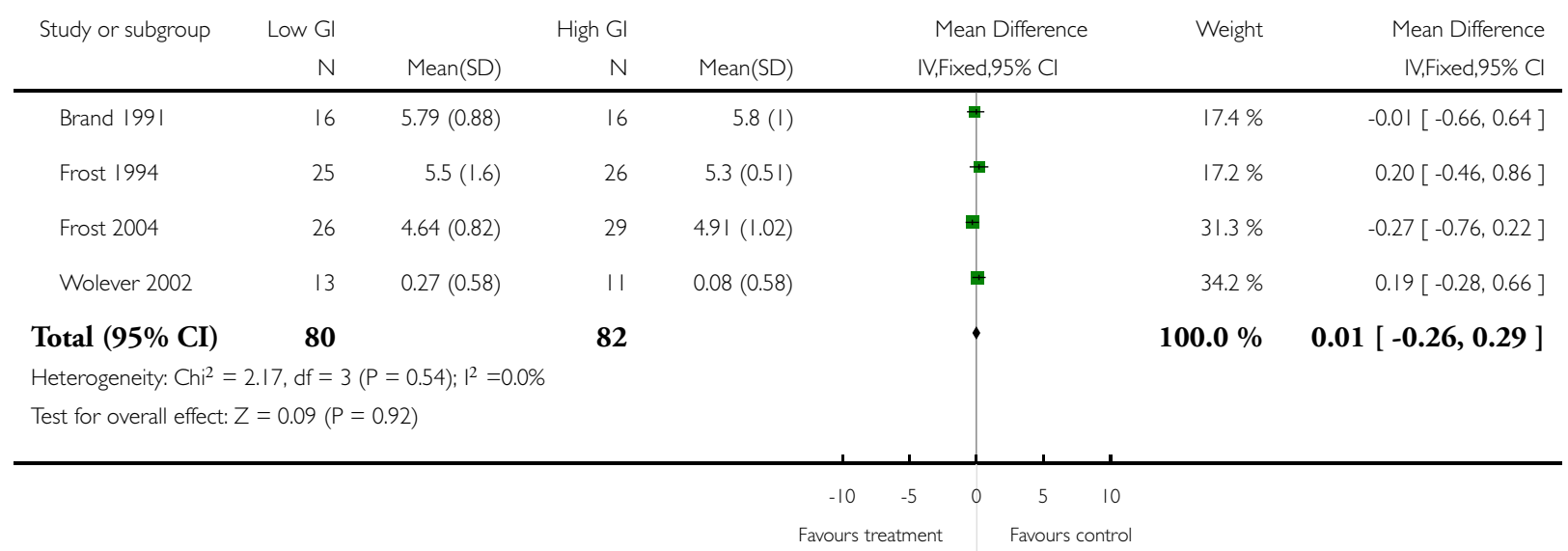


Analysis 2.3. Comparison 2 Total cholesterol (whole-diet studies only, parallel and crossover studies), Outcome 3 All endpoint outcomes ( $\mathrm{mmol} / \mathrm{L})$.

Review: Low glycaemic index diets for coronary heart disease

Comparison: 2 Total cholesterol (whole-diet studies only, parallel and crossover studies)

Outcome: 3 All endpoint outcomes ( $\mathrm{mmol} / \mathrm{L})$

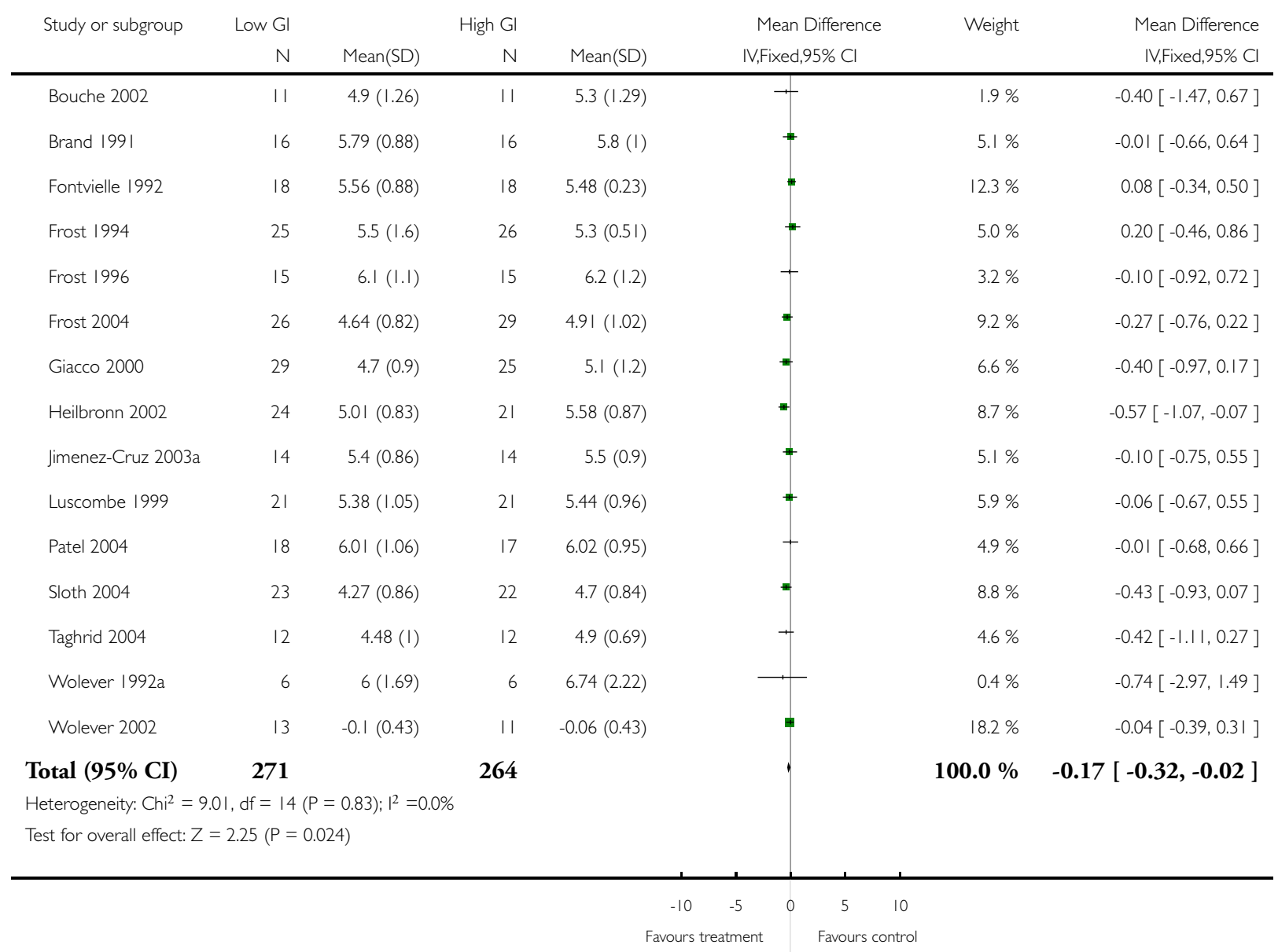


Analysis 3.I. Comparison 3 HDL cholesterol (parallel and cross-over studies), Outcome I All endpoint outcomes (mmol/L).

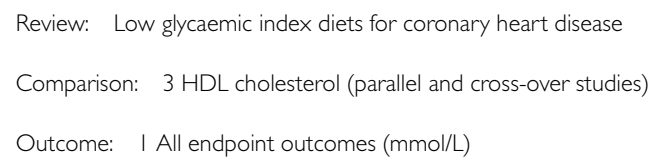

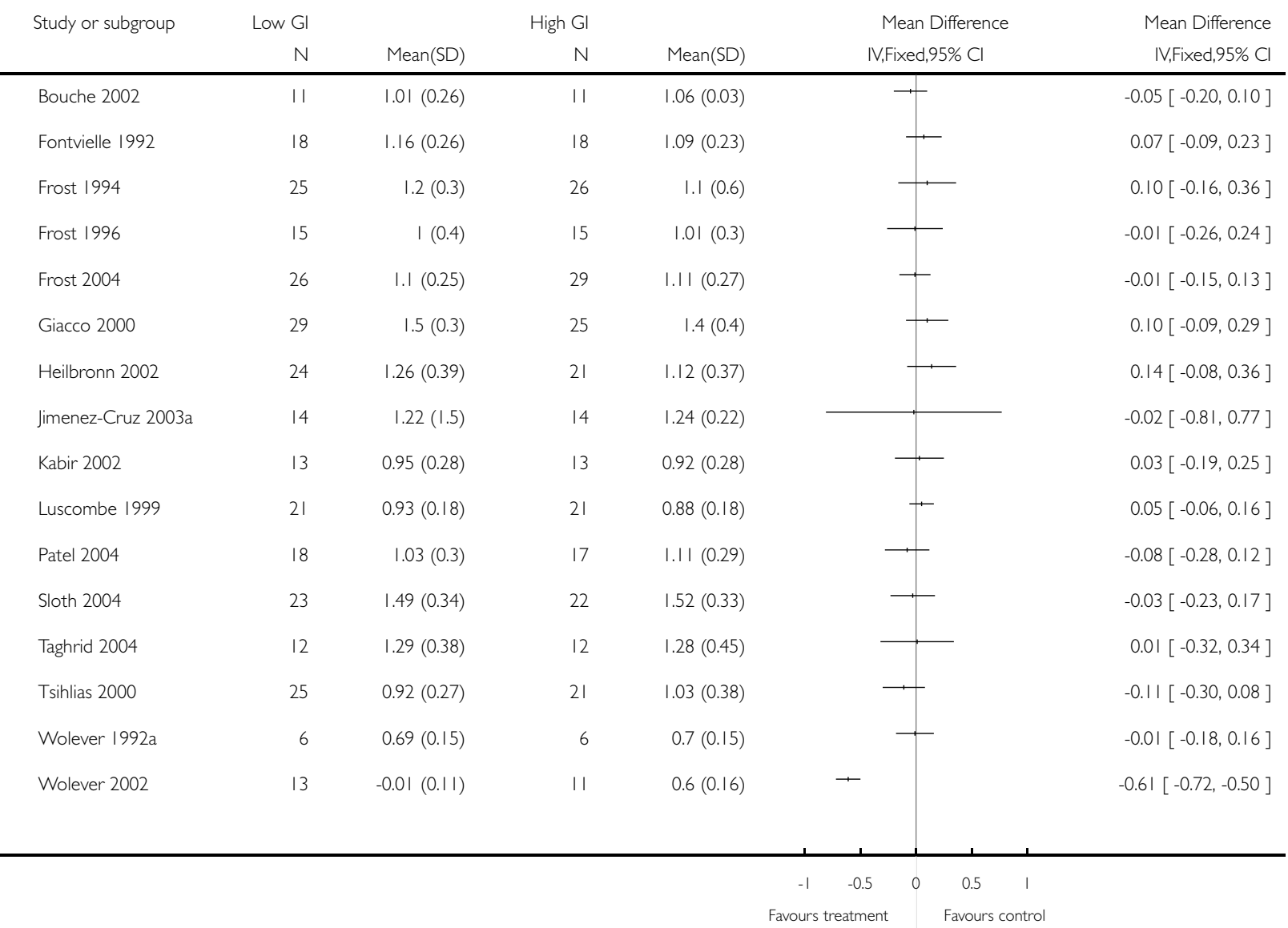


Analysis 4.I. Comparison 4 HDL cholesterol (parallel studies only), Outcome I 4 and 5 week outcomes ( $\mathrm{mmol} / \mathrm{L})$.

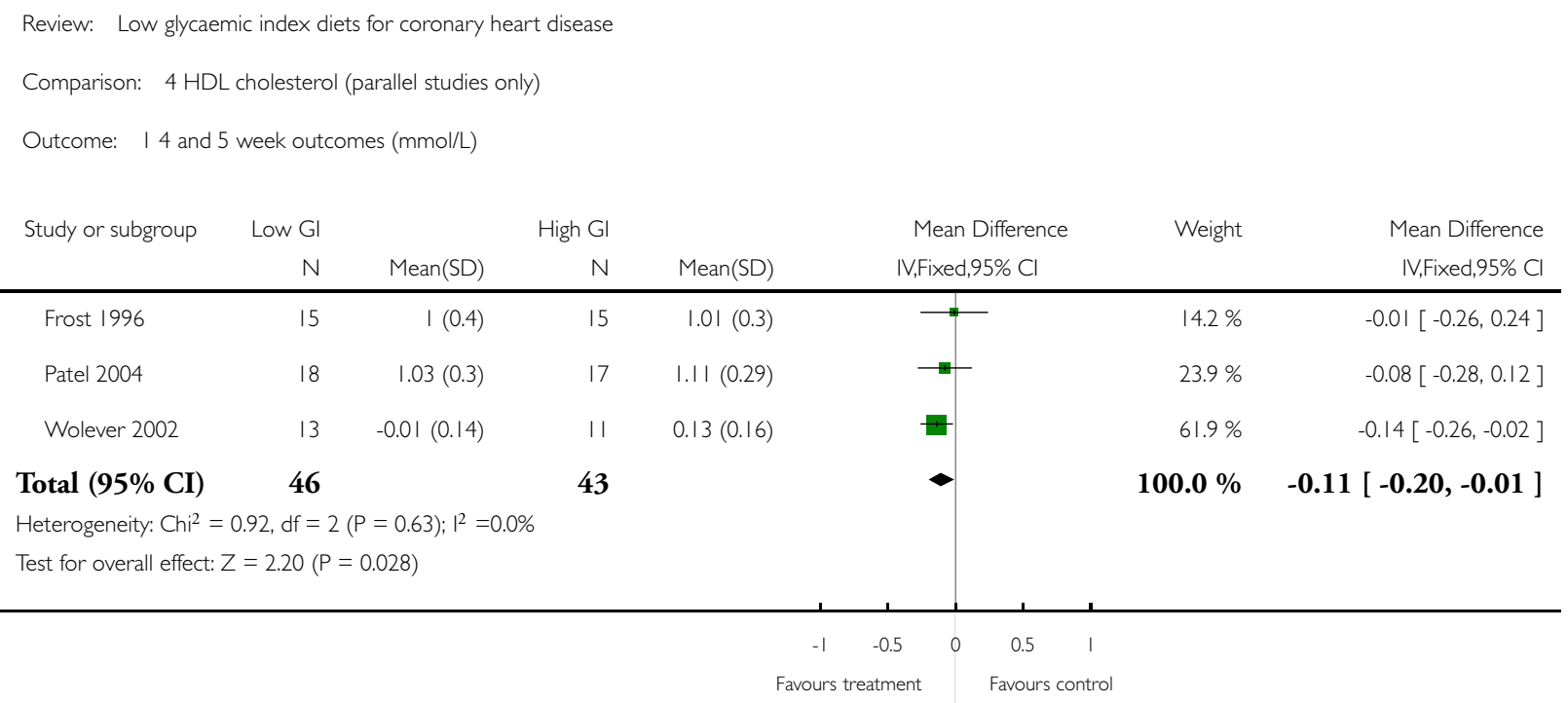

Analysis 4.2. Comparison 4 HDL cholesterol (parallel studies only), Outcome 2 I 2 week outcomes.

Review: Low glycaemic index diets for coronary heart disease

Comparison: $4 \mathrm{HDL}$ cholesterol (parallel studies only)

Outcome: 212 week outcomes

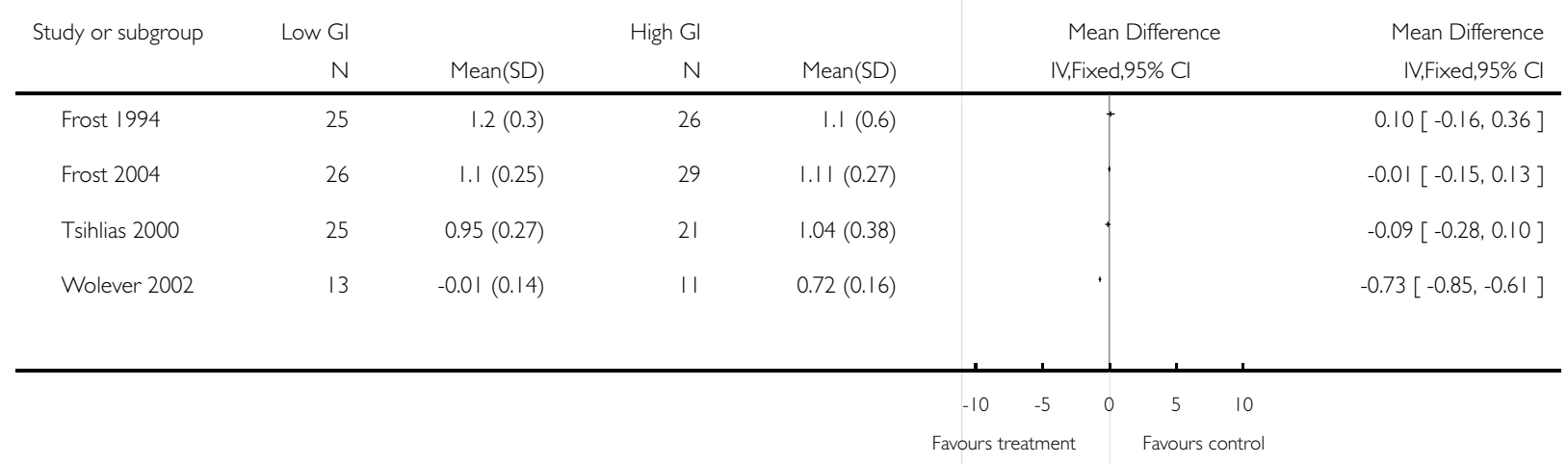


Analysis 5.I. Comparison 5 LDL cholesterol (parallel and cross-over studies), Outcome I All endpoint outcomes (mmol/L).

Review: Low glycaemic index diets for coronary heart disease

Comparison: 5 LDL cholesterol (parallel and cross-over studies)

Outcome: I All endpoint outcomes ( $\mathrm{mmol} / \mathrm{L})$

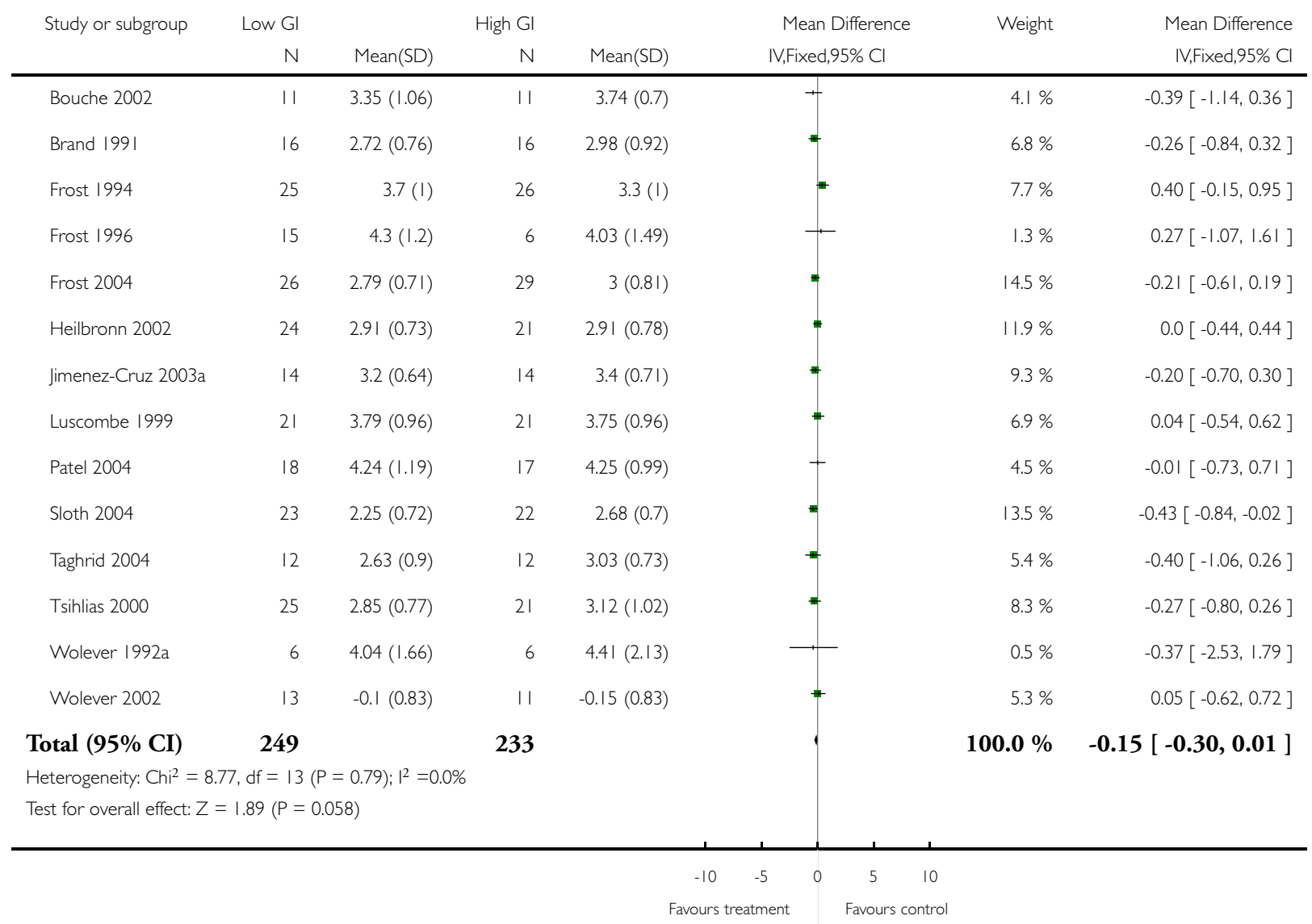


Analysis 5.2. Comparison 5 LDL cholesterol (parallel and cross-over studies), Outcome 2 All endpoint outcomes (without Wolever 2002 study).

Review: Low glycaemic index diets for coronary heart disease

Comparison: 5 LDL cholesterol (parallel and cross-over studies)

Outcome: 2 All endpoint outcomes (without Wolever 2002 study)

\begin{tabular}{|c|c|c|c|c|c|c|c|}
\hline \multirow[t]{2}{*}{ Study or subgroup } & \multirow{2}{*}{$\begin{array}{r}\text { Low Gl } \\
N\end{array}$} & \multicolumn{3}{|c|}{ High Gl } & \multirow{2}{*}{$\begin{array}{l}\text { Mean Difference } \\
\text { IV,Fixed,95\% Cl }\end{array}$} & \multirow[t]{2}{*}{ Weight } & \multirow{2}{*}{$\begin{array}{r}\text { Mean Difference } \\
\text { IV,Fixed,95\% Cl }\end{array}$} \\
\hline & & Mean(SD) & N & Mean(SD) & & & \\
\hline Bouche 2002 & 11 & $3.35(1.06)$ & 11 & $3.74(0.7)$ & + & $4.4 \%$ & $-0.39[-1.14,0.36]$ \\
\hline Brand |99| & 16 & $2.72(0.76)$ & 16 & $2.98(0.92)$ & + & $7.2 \%$ & $-0.26[-0.84,0.32]$ \\
\hline Frost 1994 & 25 & $3.7(1)$ & 26 & $3.3(1)$ & + & $8.2 \%$ & $0.40[-0.15,0.95]$ \\
\hline Frost 1996 & 15 & $4.3(1.2)$ & 6 & $4.03(1.49)$ & 7 & $1.4 \%$ & $0.27[-1.07,1.61]$ \\
\hline Frost 2004 & 26 & $2.79(0.7 \mathrm{I})$ & 29 & $3(0.81)$ & $\neq$ & $15.3 \%$ & $-0.21[-0.61,0.19]$ \\
\hline Heilbronn 2002 & 24 & $2.91(0.73)$ & 21 & $2.91(0.78)$ & $=$ & $12.5 \%$ & $0.0[-0.44,0.44]$ \\
\hline Jimenez-Cruz 2003a & 14 & $3.2(0.64)$ & 14 & $3.4(0.7 \mathrm{I})$ & $\#$ & $9.8 \%$ & $-0.20[-0.70,0.30]$ \\
\hline Luscombe 1999 & 21 & $3.79(0.96)$ & 21 & $3.75(0.96)$ & \# & $7.3 \%$ & $0.04[-0.54,0.62]$ \\
\hline Patel 2004 & 18 & $4.24(1.19)$ & 17 & $4.25(0.99)$ & - & $4.7 \%$ & $-0.01[-0.73,0.71]$ \\
\hline Sloth 2004 & 23 & $2.25(0.72)$ & 22 & $2.68(0.7)$ & $*$ & $14.3 \%$ & $-0.43[-0.84,-0.02]$ \\
\hline Taghrid 2004 & 12 & $2.63(0.9)$ & 12 & $3.03(0.73)$ & 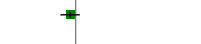 & $5.7 \%$ & $-0.40[-1.06,0.26]$ \\
\hline Tsihlias 2000 & 25 & $2.85(0.77)$ & 21 & $3.12(1.02)$ & + & $8.7 \%$ & $-0.27[-0.80,0.26]$ \\
\hline Wolever 1992a & 6 & $4.04(1.66)$ & 6 & $4.41(2.13)$ & $\longrightarrow$ & $0.5 \%$ & $-0.37[-2.53,1.79]$ \\
\hline Total (95\% CI) & 236 & & 222 & & 1 & $100.0 \%$ & $-0.16[-0.32,0.00]$ \\
\hline \multicolumn{8}{|c|}{ Heterogeneity: $\mathrm{Chi}^{2}=8.4 \mathrm{I}, \mathrm{df}=12(\mathrm{P}=0.75) ; \mathrm{I}^{2}=0.0 \%$} \\
\hline \multicolumn{8}{|c|}{ Test for overall effect: $Z=1.98(P=0.048)$} \\
\hline
\end{tabular}

Favours treatment Favours control 
Analysis 6.I. Comparison 6 Triglycerides (parallel and cross-over studies), Outcome I All endpoint data (mmol/L).

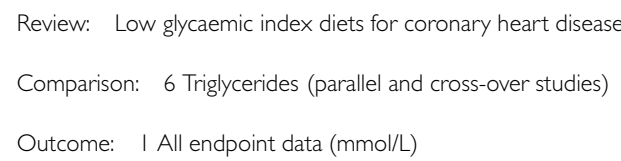

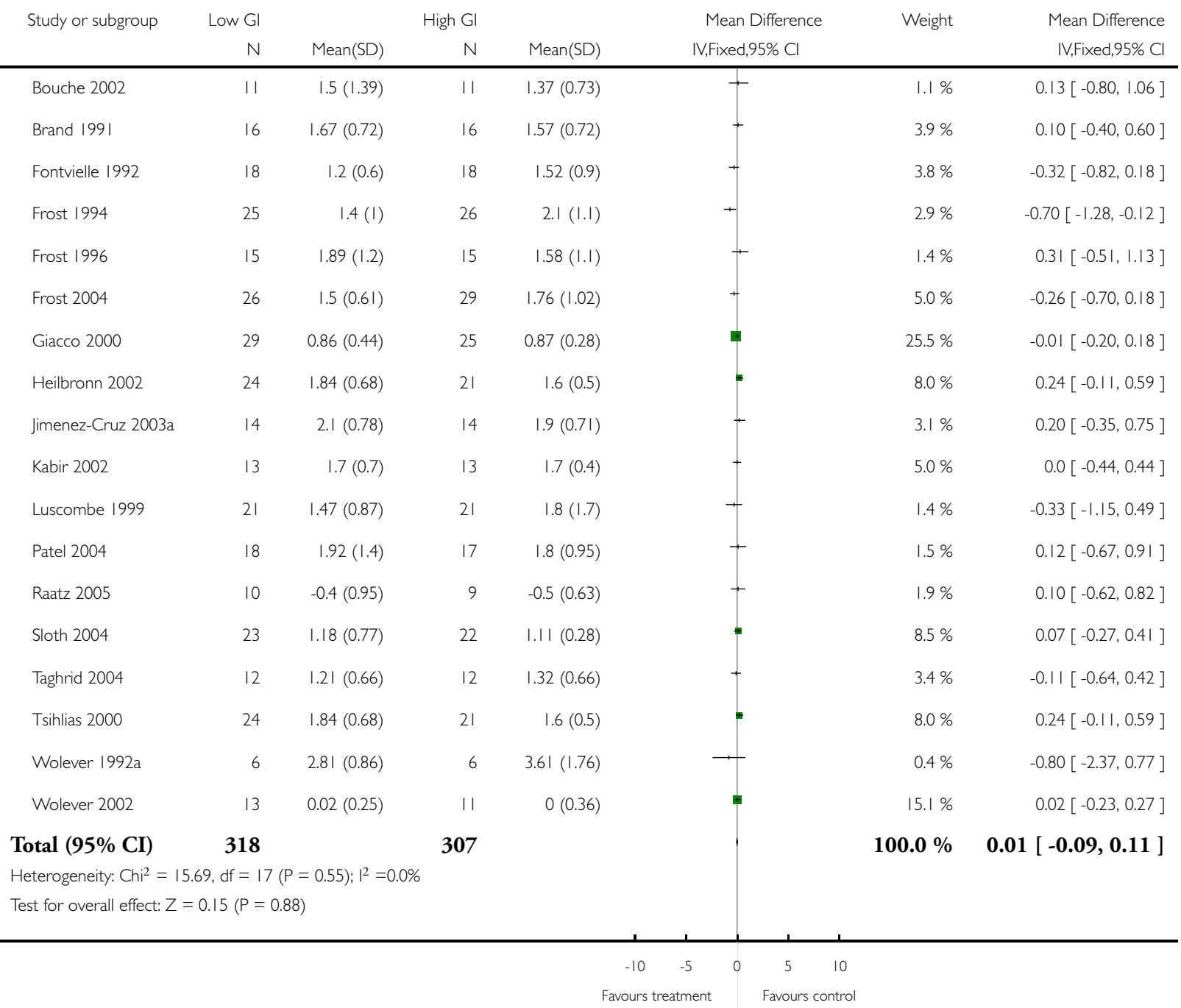




\section{Analysis 7.I. Comparison 7 Body weight (parallel and cross-over studies), Outcome I All endpoint outcomes (kg).}

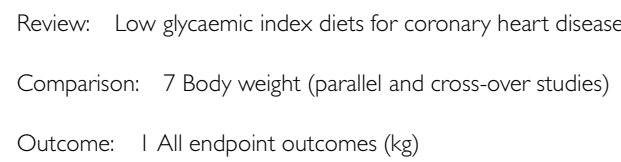

\begin{tabular}{|c|c|c|c|c|c|c|c|}
\hline \multirow[t]{2}{*}{ Study or subgroup } & \multirow{2}{*}{$\begin{array}{r}\text { Low Gl } \\
\mathrm{N}\end{array}$} & \multicolumn{3}{|c|}{ High Gl } & \multirow{2}{*}{$\begin{array}{l}\text { Mean Difference } \\
\text { IV,Fixed,95\% Cl }\end{array}$} & \multirow[t]{2}{*}{ Weight } & \multirow{2}{*}{$\begin{array}{l}\text { Mean Difference } \\
\text { IV,Fixed,95\% Cl }\end{array}$} \\
\hline & & Mean(SD) & $\mathrm{N}$ & Mean(SD) & & & \\
\hline Bouche 2002 & 11 & $85.7(9.6)$ & 11 & $86.5(9)$ & & $1.0 \%$ & $-0.80[-8.58,6.98]$ \\
\hline Brand 1991 & 16 & $75.9(\mid 4.4)$ & 16 & $76(14.4)$ & & $0.6 \%$ & $-0.10[-10.08,9.88]$ \\
\hline Carels 2005 & 27 & $96.6(15.9)$ & 26 & $94.1(15.1)$ & & $0.9 \%$ & $2.50[-5.85,10.85]$ \\
\hline Fontvielle 1992 & 18 & $70.5(10)$ & 18 & $70.7(10)$ & & $1.4 \%$ & $-0.20[-6.73,6.33]$ \\
\hline Frost 1994 & 25 & $84.8(23.5)$ & 26 & $82.9(\mid 4.8)$ & & $0.5 \%$ & $1.90[-8.93,12.73]$ \\
\hline Frost 1996 & 15 & $80.17(13.36)$ & 15 & $83.2(11.62)$ & & $0.8 \%$ & $-3.03[-11.99,5.93]$ \\
\hline Giacco 2000 & 29 & $67(11)$ & 25 & $64(11)$ & & $1.8 \%$ & $3.00[-2.88,8.88]$ \\
\hline Heilbronn 2002 & 24 & $87.3(16.2)$ & 21 & $88.4(11.9)$ & & $0.9 \%$ & $-1.10[-9.34,7.14]$ \\
\hline Jimenez-Cruz 2003a & 14 & 90.1 (23.2) & 14 & $92(24.7)$ & & $0.2 \%$ & $-1.90[-19.65,15.85]$ \\
\hline Komindr 2001 & 10 & $64.19(13.28)$ & 10 & $63.84(12.93)$ & & $0.5 \%$ & $0.35[-11.14,11.84]$ \\
\hline Luscombe 1999 & 21 & $86.2(12.4)$ & 21 & $86.5(12.8)$ & & $1.0 \%$ & $-0.30[-7.92,7.32]$ \\
\hline Raatz 2005 & 10 & $-9.95(3.6)$ & 9 & $-9.3(4.11)$ & & $5.0 \%$ & $-0.65[-4.14,2.84]$ \\
\hline Sloth 2004 & 23 & 76.76 (8.47) & 22 & $78.93(6.85)$ & & $3.0 \%$ & $-2.17[-6.66,2.32]$ \\
\hline Taghrid 2004 & 12 & $92.7(8.7)$ & 12 & $92.4(8.7)$ & & $1.3 \%$ & $0.30[-6.66,7.26]$ \\
\hline Tsihlias 2000 & 25 & $79.45(13.7)$ & 21 & $76.45(15.1)$ & & $0.9 \%$ & $3.00[-5.40,11.40]$ \\
\hline Wolever 1992a & 6 & $83.1(6.8)$ & 6 & $83.2(6.1)$ & & $1.1 \%$ & $-0.10[-7.41,7.21]$ \\
\hline Wolever 2002 & 13 & $-0.29(1.09)$ & 11 & $-0.39(1.09)$ & & $79.2 \%$ & $0.10[-0.78,0.98]$ \\
\hline Total $(95 \% \mathrm{CI})$ & 299 & & 284 & & $\rightarrow$ & $100.0 \%$ & $0.04[-0.73,0.82]$ \\
\hline \multicolumn{8}{|c|}{ Heterogeneity: $\mathrm{Chi}^{2}=3.63, \mathrm{df}=16(\mathrm{P}=1.00) ; \mathrm{I}^{2}=0.0 \%$} \\
\hline \multicolumn{8}{|c|}{ Test for overall effect: $Z=0.11(P=0.91)$} \\
\hline
\end{tabular}

Favours treatment Favours control 
Analysis 8.I. Comparison 8 Fasting glucose (parallel and cross-over studies), Outcome I All endpoint outcomes $(\mathrm{mmol} / \mathrm{L})$.

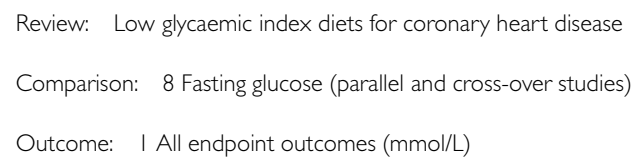

\begin{tabular}{|c|c|c|c|c|c|c|c|}
\hline \multirow[t]{2}{*}{ Study or subgroup } & \multirow{2}{*}{$\begin{array}{r}\text { Low } \mathrm{Gl} \\
\mathrm{N} \\
\end{array}$} & \multicolumn{3}{|c|}{ High Gl } & \multirow{2}{*}{$\begin{array}{l}\text { Mean Difference } \\
\text { IV,Fixed,95\% Cl }\end{array}$} & \multirow[t]{2}{*}{ Weight } & \multirow{2}{*}{$\begin{array}{r}\text { Mean Difference } \\
\text { IV,Fixed,95\% Cl }\end{array}$} \\
\hline & & Mean(SD) & $\mathrm{N}$ & Mean(SD) & & & \\
\hline Bouche 2002 & 11 & $5.36(0.36)$ & 11 & $5.26(0.36)$ & 甲 & $15.7 \%$ & $0.10[-0.20,0.40]$ \\
\hline Brand |99| & 16 & $7(1.6)$ & 16 & $7.1(3.2)$ & $\longrightarrow$ & $0.5 \%$ & $-0.10[-1.85,1.65]$ \\
\hline Fontvielle 1992 & 18 & $10.9(5.1)$ & 18 & II.7 (4.7) & ?' & $0.1 \%$ & $-0.80[-4.00,2.40]$ \\
\hline Frost 1994 & 25 & $9.6(3)$ & 26 & $9.8(3)$ & $\longrightarrow$ & $0.5 \%$ & $-0.20[-1.85,1.45]$ \\
\hline Frost 1996 & 15 & $7.3(1.16)$ & 15 & $6.2(0.77)$ & + & $2.9 \%$ & $1.10[0.40,1.80]$ \\
\hline Frost 2004 & 26 & $5.49(0.82)$ & 29 & $5.16(0.51)$ & $=$ & $10.6 \%$ & $0.33[-0.04,0.70]$ \\
\hline Heilbronn 2002 & 24 & $6.47(1.91)$ & 21 & $6.08(1.14)$ & + & $1.7 \%$ & $0.39[-0.52,1.30]$ \\
\hline Jimenez-Cruz 2003a & 14 & $8.9(2.47)$ & 14 & $10(3.7)$ & $\longrightarrow$ & $0.3 \%$ & $-1.10[-3.43,1.23]$ \\
\hline Kabir 2002 & 13 & $10.6(1.1)$ & 13 & $10.1(2.5)$ & $\rightarrow$ & $0.6 \%$ & $0.50[-0.98,1.98]$ \\
\hline Luscombe 1999 & 21 & $9.7(3.2)$ & 21 & $9.8(3.7)$ & $\longrightarrow$ & $0.3 \%$ & $-0.10[-2.19,1.99]$ \\
\hline Patel 2004 & 18 & $6.2(0.85)$ & 17 & $6.3(1.24)$ & + & $2.8 \%$ & $-0.10[-0.81,0.61]$ \\
\hline Raatz 2005 & 10 & $-0.2(0.32)$ & 9 & $-0.3(0.32)$ & 甲 & $17.1 \%$ & $0.10[-0.19,0.39]$ \\
\hline Sloth 2004 & 23 & $4.82(0.29)$ & 22 & $4.72(0.33)$ & 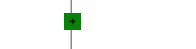 & $43.0 \%$ & $0.10[-0.08,0.28]$ \\
\hline Taghrid 2004 & 12 & $9.19(2.42)$ & 12 & $9.75(1.97)$ & 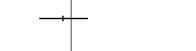 & $0.5 \%$ & $-0.56[-2.33,1.21]$ \\
\hline Tsihlias 2000 & 25 & $9.2(2.7)$ & 21 & $8.8(2.7)$ & + & $0.6 \%$ & $0.40[-1.17,1.97]$ \\
\hline Wolever 1992a & 6 & $8.4(1.7)$ & 6 & $8.4(1.5)$ & $\longrightarrow$ & $0.4 \%$ & $0.0[-|.8|,|.8|]$ \\
\hline Wolever 2002 & 13 & $5.12(0.97)$ & 9 & $5.45(0.93)$ & + & $2.2 \%$ & $-0.33[-1.13,0.47]$ \\
\hline Total $(95 \%$ CI $)$ & 290 & & 280 & & ' & $100.0 \%$ & $0.14[0.02,0.26]$ \\
\hline \multicolumn{8}{|c|}{ Heterogeneity: $\mathrm{Chi}^{2}=13.20, \mathrm{df}=16(P=0.66) ; 1^{2}=0.0 \%$} \\
\hline \multicolumn{8}{|c|}{ Test for overall effect: $Z=2.24(P=0.025)$} \\
\hline
\end{tabular}

Favours treatment Favours control 
Analysis 9.1. Comparison 9 Fasting insulin (parallel and cross-over studies), Outcome I All endpoint outcomes.

Review: Low glycaemic index diets for coronary heart disease

Comparison: 9 Fasting insulin (parallel and cross-over studies)

Outcome: I All endpoint outcomes

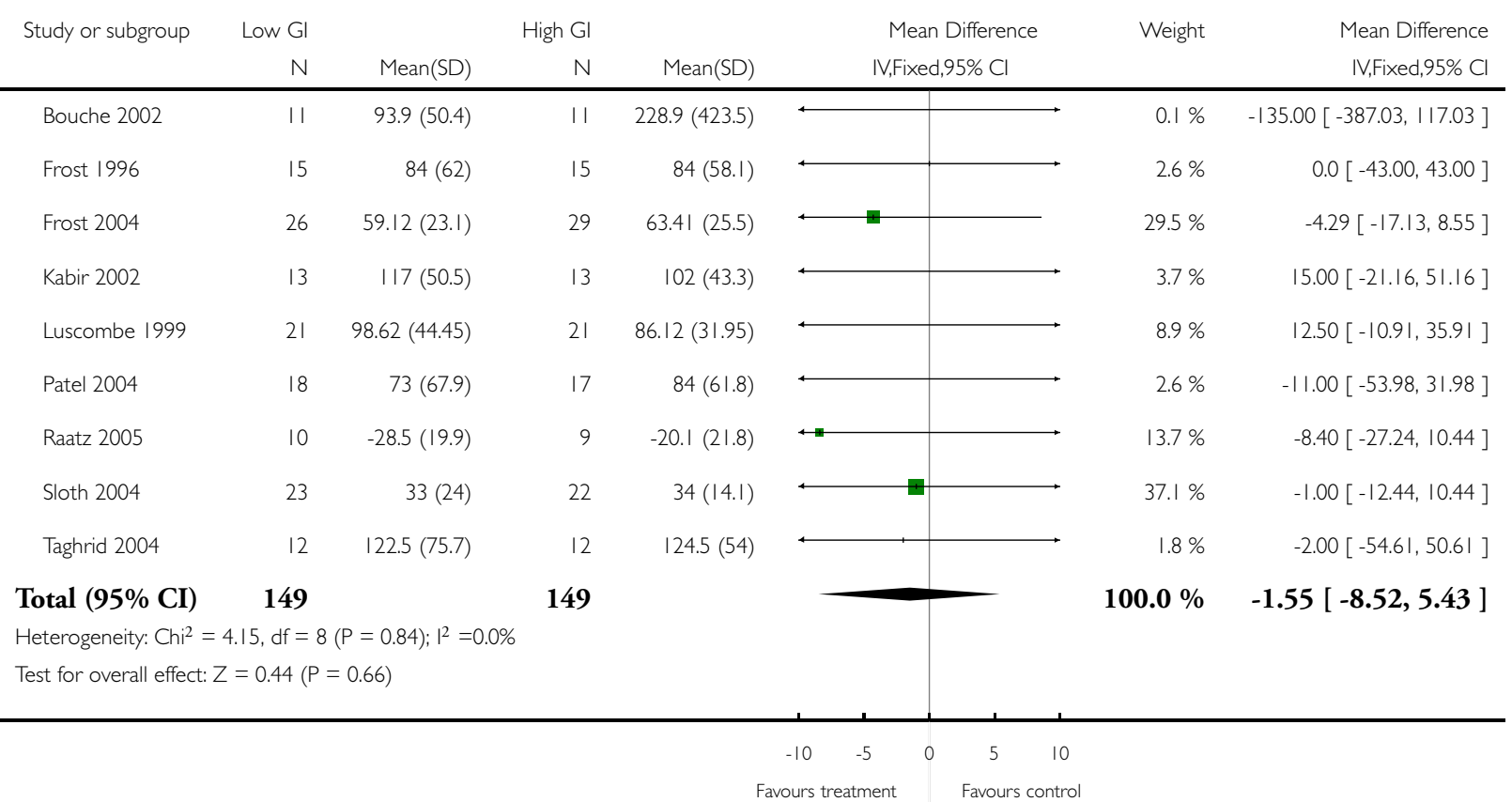


Analysis 10.I. Comparison $10 \mathrm{HbAlc}$ (parallel and cross-over studies), Outcome I All endpoint outcomes (\%).

Review: Low glycaemic index diets for coronary heart disease

Comparison: $10 \mathrm{HbAlc}$ (parallel and cross-over studies)

Outcome: I All endpoint outcomes (\%)

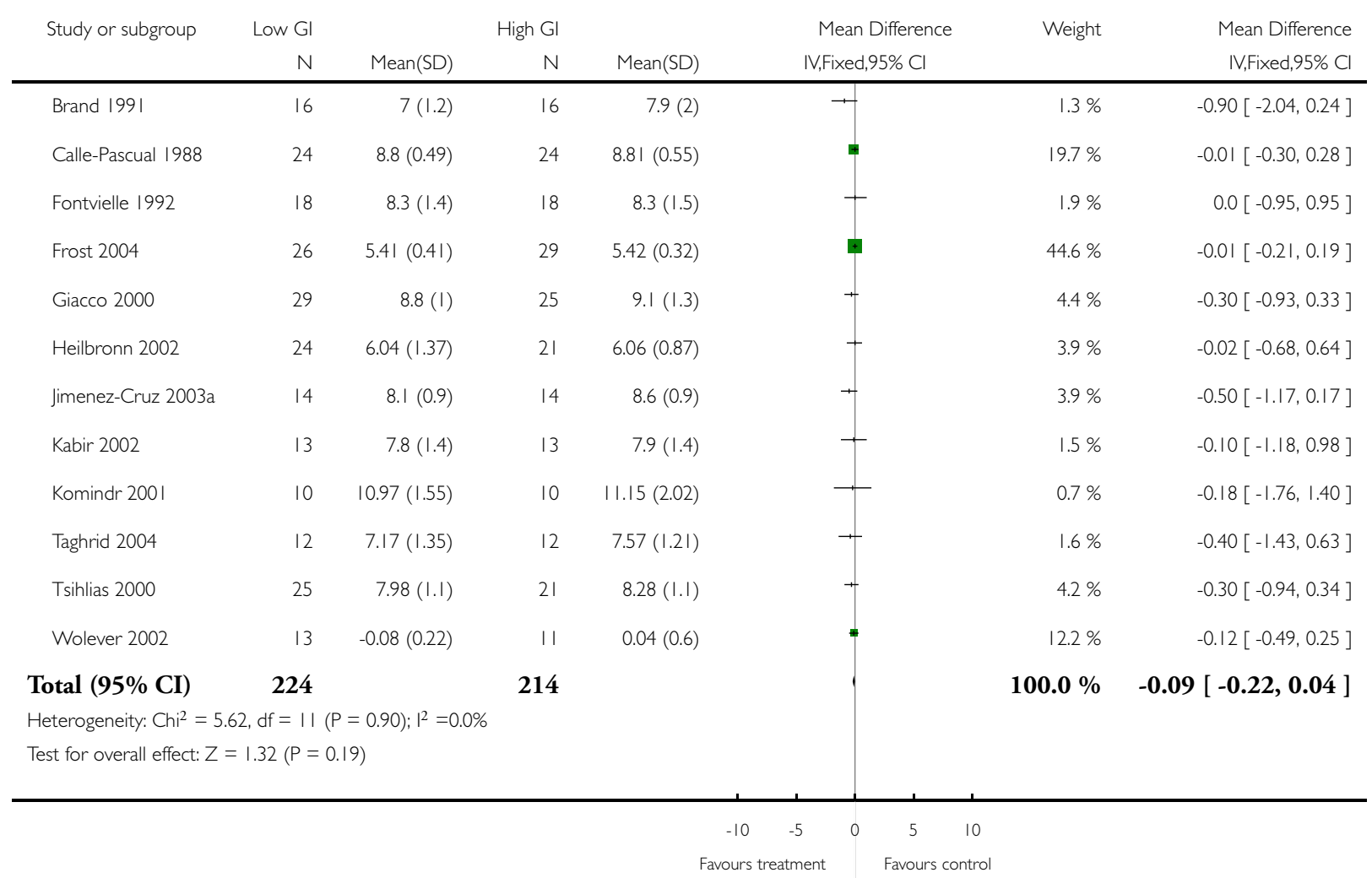


Analysis 10.2. Comparison 10 HbAlc (parallel and cross-over studies), Outcome 2 I 2 week outcomes (\%).

Review: Low glycaemic index diets for coronary heart disease

Comparison: $10 \mathrm{HbAlc}$ (parallel and cross-over studies)

Outcome: 212 week outcomes (\%)

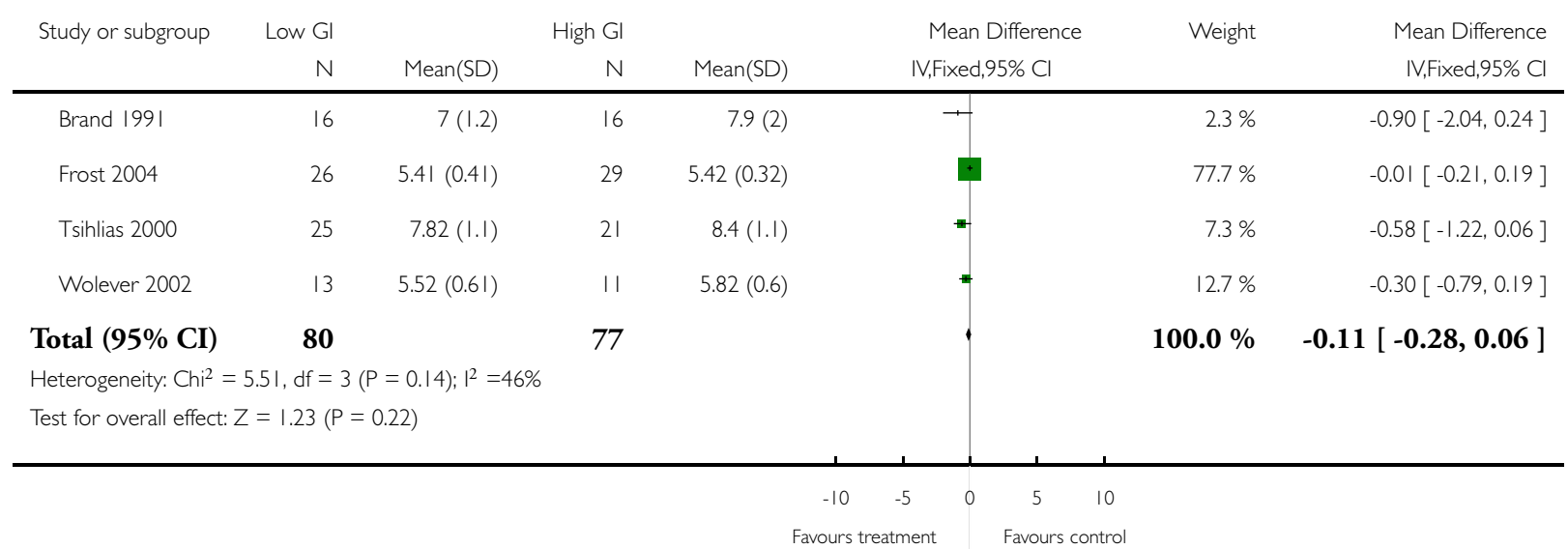

Analysis 10.3. Comparison $10 \mathrm{HbAlc}$ (parallel and cross-over studies), Outcome 3 I 2 week outcomes (\%) without Frost 1996.

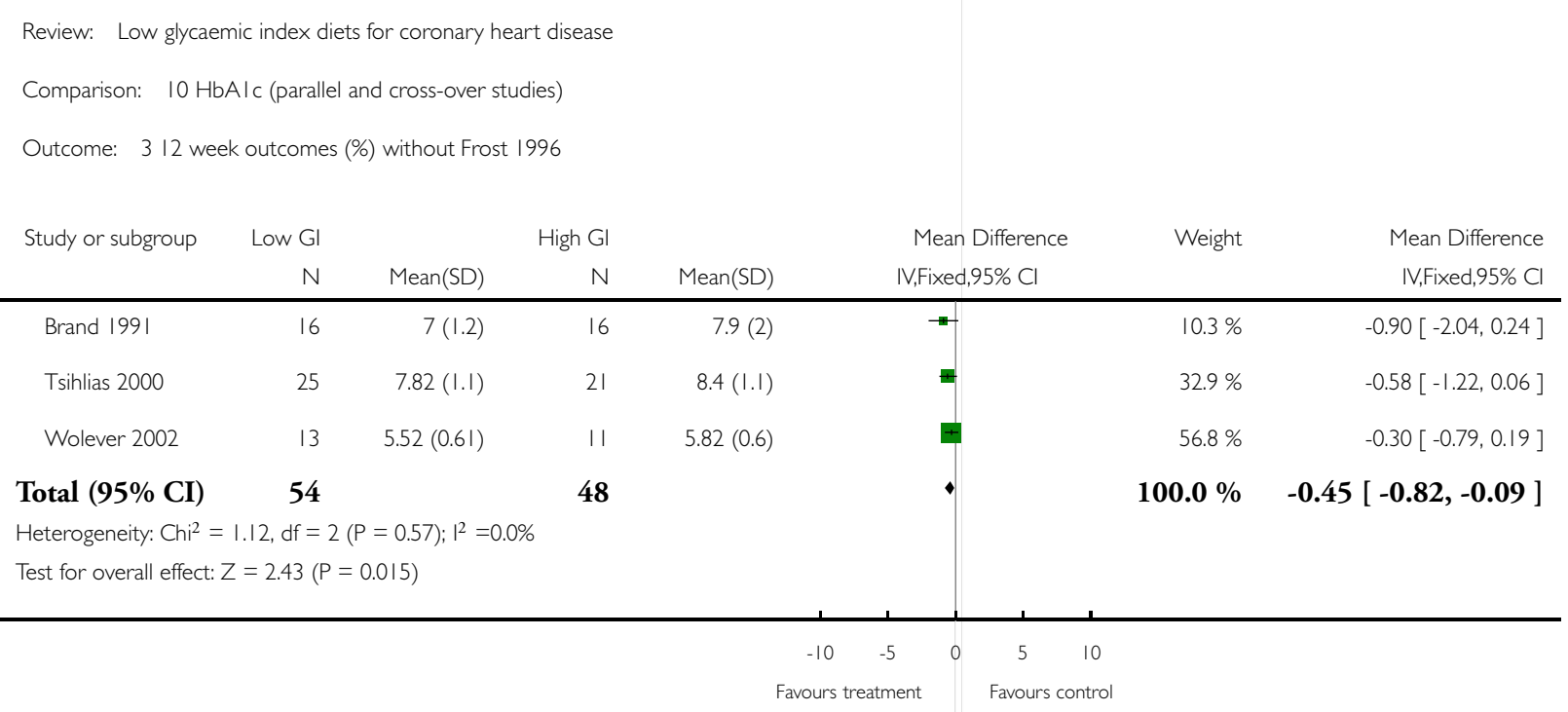




\section{A P P E N D I CES}

\section{Appendix I. Search strategies}

\section{CENTRAL search}

1. glyc?emic index.tw.

2. (glyc?emic adj3 low).tw.

3. (glyc?emic adj3 diet\$).tw.

4. (carbohydrate $\$$ adj25 diet\$).ab,ti.

5. (starch\$ adj25 diet\$).ab,ti.

6. 1 or 2 or 3 or 4 or 5

7. coronary $\$ . a b, t i$.

8. cardiovascular\$.ab,ti.

9. heart\$.ab,ti.

10. chd.ab,ti.

11. angina.ab,ti.

12. cvd.ab,ti.

13. ischemic $\$$.ab,ti.

14. myocardial\$.ab,ti.

15. cardiac $\$$.ab,ti.

16. lipid\$.ab,ti.

17. cholesterol\$.ab,ti.

18. blood pressure.ab,ti.

19. obes $\$ . a b, t i$.

20. diabet\$.ab,ti.

21. glyc?emic.ab,ti.

22.7 or 8 or 9 or 10 or 11 or 12 or 13 or 14 or 15 or 16 or 17 or 18 or 19 or 20 or 21

23.6 and 22

24. random\$.ab,ti.

25. compar\$.ab,ti.

26. control\$.ab,ti.

27. study.ab,ti.

28. follow\$ up.ab,ti.

29. clinic $\$ . a b, t i$.

30. blind\$.ab,ti.

31. double\$.ab,ti.

32. cross?over.ab,ti.

33. 24 or 25 or 26 or 27 or 28 or 29 or 30 or 31 or 32

34.23 and 33

\section{MEDLINE search}

1. Glycemic Index/

2. (glyc?emic adj3 low).tw.

3. glyc?emic index.tw.

4. (glyc?emic adj3 diet\$).tw.

5. 1 or 2 or 3 or 4

6. exp Dietary Carbohydrates/

7. CARBOHYDRATES/

8. carbohydrate\$.tw.

9. $\operatorname{starch}^{*} /$ 
10. or/6-9

11. exp Coronary Disease/

12. Cardiovascular Diseases/

13. heart disease\$.tw.

14. coronary disease $\$$. tw.

15. chd.tw.

16. cardiovascular.tw.

17. angina.tw.

18. cvd.tw.

19.11 or 12 or 13 or 14 or 15 or 16 or 17 or 18

20. 10 and 19

21.5 or 20

22. randomized controlled trial.pt.

23. controlled clinical trial.pt.

24. Randomized controlled trials/

25. random allocation.sh.

26. double blind method.sh.

27. single-blind method.sh.

28. 22 or 23 or 24 or 25 or 26 or 27

29. (animal not human).sh.

30. 28 not 29

31. clinical trial.pt.

32. exp Clinical Trials/

33. (clin\$ adj25 trial\$).ab,ti.

34. ((singl\$ or doubl $\$$ or trebl\$ or tripl\$) adj (blind $\$$ or mask $\$)$ ).ab,ti.

35. placebos.sh.

36. placebo\$.ab,ti.

37. random $\$ . a b$, ti.

38. research design.sh.

39.31 or 32 or 33 or 34 or 35 or 36 or 37 or 38

40.39 not 29

41. 40 not 30

42. comparative study.sh.

43. exp Evaluation Studies/

44. follow up studies.sh.

45. prospective studies.sh.

46. (control\$ or prospectiv\$ or volunteer\$).ab,ti.

47.42 or 43 or 44 or 45 or 46

48.47 not 29

49. 48 not (30 or 41$)$

50.30 or 41 or 49

51. 21 and 50

\section{EMBASE search}

1. (glyc?emic adj3 low).tw.

2. (glyc?emic adj3 diet\$).tw.

3. glyc?emic index.tw,ti.

4. 1 or 2 or 3

5. exp Carbohydrate Diet/

6. Carbohydrate/

7. carbohydrate\$.tw.

8. $\exp$ STARCH/

Low glycaemic index diets for coronary heart disease (Review)

Copyright ( 2008 The Cochrane Collaboration. Published by John Wiley \& Sons, Ltd. 
9. 5 or 6 or 7 or 8

10. exp Ischemic Heart Disease/

11. exp Coronary Artery Disease/

12. Cardiovascular Disease/

13. heart disease\$.tw.

14. coronary disease $\$$.tw.

15. chd.tw.

16. cardiovascular.tw.

17. angina.tw.

18. cvd.tw.

19. 10 or 11 or 12 or 13 or 14 or 15 or 16 or 17 or 18

20.9 and 19

21. 4 or 20

22. Controlled Study/

23. Clinical Trial/

24. random $\$$.ab,ti.

25. compar\$.ab,ti.

26. control\$.ab,ti.

27. study.ab,ti.

28. follow $\$$ up.ab,ti.

29. clinic $\$$.ab,ti.

30. blind\$.ab,ti.

31. Double Blind Procedure/

32. double\$.ab,ti.

33. 22 or 23 or 24 or 25 or 26 or 27 or 28 or 29 or 30 or 31 or 32

34. 21 and 33

\section{CINAHL search}

1. exp Glycemic Index/

2. (glyc?emic adj3 low).tw.

3. glyc?emic index.tw.

4. (glyc?emic adj3 diet\$).tw.

5. 1 or 2 or 3 or 4

6. exp Dietary Carbohydrates/

7. CARBOHYDRATES/

8. carbohydrate $\$$.tw.

9. 6 or 7 or 8

10. exp Coronary Disease/

11. Cardiovascular Diseases/

12. heart disease\$.tw.

13. chd.tw.

14. cardiovascular.tw.

15. angina.tw.

16. cvd.tw.

17. 10 or 11 or 12 or 13 or 14 or 15 or 16

18. 9 and 17

19.5 or 18

20. clinical trial.pt.

21. exp Clinical Trials/

22. (clin\$ adj25 trial\$).tw.

23. ( (singl\$ or doubl $\$$ or trebl\$ or tripl\$) adj (blind $\$$ or mask $\$))$.tw. 24. PLACEBOS/

Low glycaemic index diets for coronary heart disease (Review)

Copyright @ 2008 The Cochrane Collaboration. Published by John Wiley \& Sons, Ltd. 
25. placebo\$.tw.

26. random $\$$.tw.

27. exp Evaluation Research/

28. exp Prospective Studies/

29. Random Assignment/

30. Random Sample/

31. Crossover Design/

32. Comparative Studies/

33. 20 or 21 or 22 or 23 or 24 or 25 or 26 or 27 or 28 or 29 or 30 or 31 or 32

34.19 and 33

\section{WHAT'S NEW}

Last assessed as up-to-date: 14 May 2006.

15 May 2006 New search has been performed The search was updated to July 2006. Six new studies were identified and added to the review. There is no change to the conclusions of the review.

\section{H I S T O R Y}

Protocol first published: Issue 4, 2003

Review first published: Issue 4, 2004

8 April 2008 Amended Converted to new review format. 


\section{CONTRIBUTIONSOFAUTHORS}

Dr S Kelly

Prepared and designed the protocol. Developed and ran the search strategy. Organised the retrieval of papers and screened papers for inclusion and exclusion. Extracted data from papers that were included and took the primary role in writing the review. For the update of the review, ran the search strategy, organised the retrieval of papers, screened papers for inclusion and exclusion, extracted data from included papers and took the primary role in writing the review.

Dr G Frost

Conceived the review and obtained funding. Provided a methodological, policy and clinical perspective on the data.

Dr C Summerbell

For the original review, screened papers for inclusion and exclusion and extracted data from papers that were included in the review for the purpose of dual data collection. Provided a methodological, policy and clinical perspective on the data.

Mrs V Whittaker

Advised on meta-analysis and quality assessment of studies. For the update of the review, extracted data from papers and advised on statistics and quality assessment of studies.

\section{DECLARATIONS OF INTEREST}

Gary Frost and Carolyn Summerbell are qualified dietitians.

\section{SOURCES OF SUPPORT}

\section{Internal sources}

- School of Health, University of Teesside, UK.

- Hammersmith Hospital, UK.

\section{External sources}

- No sources of support supplied

\section{N DEX TERMS}

\section{Medical Subject Headings (MeSH)}

*Glycemic Index; Blood Glucose [metabolism]; Cholesterol [blood]; Coronary Disease [mortality; *prevention \& control]; Dietary Carbohydrates [administration \& dosage; *metabolism]; Fasting [metabolism] 


\section{MeSH check words}

Humans 